\title{
Present state of global wetland extent and wetland methane modelling: conclusions from a model inter-comparison project (WETCHIMP)
}

\author{
J. R. Melton ${ }^{1,{ }^{*}}$, R. Wania ${ }^{2, * *}$, E. L. Hodson ${ }^{3, * * *}$, B. Poulter ${ }^{4}$, B. Ringeval ${ }^{4,5,6}$, R. Spahni ${ }^{7}$, T. Bohn ${ }^{8}$, C. A. Avis ${ }^{9}$, \\ D. J. Beerling ${ }^{10}$, G. Chen ${ }^{11}$, A. V. Eliseev ${ }^{12,13}$, S. N. Denisov ${ }^{12}$, P. O. Hopcroft ${ }^{5}$, D. P. Lettenmaier ${ }^{8}$, W. J. Riley ${ }^{14}$,
} J. S. Singarayer ${ }^{5}$, Z. M. Subin ${ }^{14}$, H. Tian ${ }^{11}$, S. Zürcher ${ }^{7}$, V. Brovkin ${ }^{15}$, P. M. van Bodegom ${ }^{16}$, T. Kleinen ${ }^{15}$, Z. C. Yu $^{17}$, and J. O. Kaplan ${ }^{1}$

${ }^{1}$ ARVE Group, École Polytechnique Fédérale de Lausanne, Switzerland

${ }^{2}$ Institut des Sciences de l'Evolution (UMR 5554, CNRS), Université Montpellier 2, Place Eugène Bataillon, 34090

Montpellier, France

${ }^{3}$ Swiss Federal Research Institute WSL, Switzerland

${ }^{4}$ Laboratoire des Sciences du Climat et de l'Environment, CNRS-CEA, UVSQ, Gif-sur Yvette, France

${ }^{5}$ BRIDGE, School of Geographical Sciences, Univerity of Bristol, UK

${ }^{6}$ VU University Amsterdam, Department of Earth Sciences, Amsterdam, The Netherlands

${ }^{7}$ Climate and Environmental Physics, Physics Institute \& Oeschger Centre for Climate Change Research,

University of Bern, Switzerland

${ }^{8}$ Dept. of Civil and Environmental Engineering, University of Washington, USA

${ }^{9}$ School of Earth and Ocean Sciences, University of Victoria, Canada

${ }^{10}$ Dept. of Animal and Plant Sciences, University of Sheffield, Sheffield S10 2TN, UK

${ }^{11}$ International Center for Climate and Global Change Research and School of Forestry and Wildlife Sciences, Auburn

University, Auburn, AL 36849, USA

${ }^{12}$ A.M. Obukhov Institute of Atmospheric Physics, Russian Academy of Sciences, Russia

${ }^{13}$ Kazan (Volga Region) Federal University. Kazan, Russia

${ }^{14}$ Earth Sciences Division (ESD) Lawrence Berkeley National Lab, USA

${ }^{15}$ Max Planck Institute for Meteorology, Hamburg, Germany

${ }^{16}$ Department of Ecological Sciences, VU University, Amsterdam, The Netherlands

${ }^{17}$ Department of Earth and Environmental Sciences, Lehigh University, USA

*now at: Canadian Centre for Climate Modelling and Analysis, Environment Canada, Victoria, BC, V8W 2Y2, Canada

** Lanser Strasse 30, 6080 Igls, Austria

**** now at: AAAS Science and Technology Policy Fellow, Office of Climate Change Policy and Technology,

US Department of Energy, USA

Correspondence to: J. R. Melton (joe.melton.sci@gmail.com)

Received: 30 July 2012 - Published in Biogeosciences Discuss.: 27 August 2012

Revised: 10 December 2012 - Accepted: 12 December 2012 - Published: 4 February 2013

\begin{abstract}
Global wetlands are believed to be climate sensitive, and are the largest natural emitters of methane $\left(\mathrm{CH}_{4}\right)$. Increased wetland $\mathrm{CH}_{4}$ emissions could act as a positive feedback to future warming. The Wetland and Wetland $\mathrm{CH}_{4}$ Inter-comparison of Models Project (WETCHIMP) inves-
\end{abstract}

tigated our present ability to simulate large-scale wetland characteristics and corresponding $\mathrm{CH}_{4}$ emissions. To ensure inter-comparability, we used a common experimental protocol driving all models with the same climate and carbon dioxide $\left(\mathrm{CO}_{2}\right)$ forcing datasets. The WETCHIMP experiments 
were conducted for model equilibrium states as well as transient simulations covering the last century. Sensitivity experiments investigated model response to changes in selected forcing inputs (precipitation, temperature, and atmospheric $\mathrm{CO}_{2}$ concentration). Ten models participated, covering the spectrum from simple to relatively complex, including models tailored either for regional or global simulations. The models also varied in methods to calculate wetland size and location, with some models simulating wetland area prognostically, while other models relied on remotely sensed inundation datasets, or an approach intermediate between the two.

Four major conclusions emerged from the project. First, the suite of models demonstrate extensive disagreement in their simulations of wetland areal extent and $\mathrm{CH}_{4}$ emissions, in both space and time. Simple metrics of wetland area, such as the latitudinal gradient, show large variability, principally between models that use inundation dataset information and those that independently determine wetland area. Agreement between the models improves for zonally summed $\mathrm{CH}_{4}$ emissions, but large variation between the models remains. For annual global $\mathrm{CH}_{4}$ emissions, the models vary by $\pm 40 \%$ of the all-model mean $\left(190 \mathrm{Tg} \mathrm{CH}_{4} \mathrm{yr}^{-1}\right)$. Second, all models show a strong positive response to increased atmospheric $\mathrm{CO}_{2}$ concentrations $(857 \mathrm{ppm})$ in both $\mathrm{CH}_{4}$ emissions and wetland area. In response to increasing global temperatures $\left(+3.4^{\circ} \mathrm{C}\right.$ globally spatially uniform), on average, the models decreased wetland area and $\mathrm{CH}_{4}$ fluxes, primarily in the tropics, but the magnitude and sign of the response varied greatly. Models were least sensitive to increased global precipitation $(+3.9 \%$ globally spatially uniform) with a consistent small positive response in $\mathrm{CH}_{4}$ fluxes and wetland area. Results from the 20th century transient simulation show that interactions between climate forcings could have strong non-linear effects. Third, we presently do not have sufficient wetland methane observation datasets adequate to evaluate model fluxes at a spatial scale comparable to model grid cells (commonly $0.5^{\circ}$ ). This limitation severely restricts our ability to model global wetland $\mathrm{CH}_{4}$ emissions with confidence. Our simulated wetland extents are also difficult to evaluate due to extensive disagreements between wetland mapping and remotely sensed inundation datasets. Fourth, the large range in predicted $\mathrm{CH}_{4}$ emission rates leads to the conclusion that there is both substantial parameter and structural uncertainty in large-scale $\mathrm{CH}_{4}$ emission models, even after uncertainties in wetland areas are accounted for.

\section{Introduction}

Global wetlands are an important component of the hydrologic and carbon cycles. Wetlands influence groundwater recharge, gross water balance, flood response, and river flow variability including base and low flows
(Bullock and Acreman, 2003). Geographically, about $44 \%$ of global wetlands occur in the high northern latitudes (OECD, 1996) where they can be influenced by permafrost controls on hydrology (Woo and Winter, 1993; Woo and Young, 2006). The remainder of global wetlands are primarily located in the tropical and subtropical humid regions; of those, about $30 \%$ occur in arid and sub-arid areas (OECD, 1996). The slow decomposition rates of organic matter in wetlands allow accumulation of carbon in the soil. Thus, while wetlands cover about $6 \%-7 \%$ of the Earth's surface (OECD, 1996; Lehner and Döll, 2004), they account for a disproportionate share of the terrestrial soil carbon pool. The vast majority of this wetland carbon is stored in peatland soils, primarily in the northern boreal and sub-arctic regions where estimated peat carbon stocks range between $\sim 270$ and $\sim 600 \mathrm{PgC}$ (Gorham, 1991; Turunen et al., 2002; Yu et al., 2010; Yu, 2012), with some important locations in the tropics estimated to contain a further $\sim 90 \mathrm{PgC}$ (Page et al., 2011). Wetlands, especially eutrophic and mesotrophic wetlands, are also often more productive than other ecosystems in the same climatic zone. For example, Peregon et al. (2008) estimated average net primary productivity (NPP) for wetlands of the West Siberian Lowlands to be $\sim 400 \mathrm{~g} \mathrm{Cm}^{2} \mathrm{yr}^{-1}$, which is higher than the average NPP of boreal forests (about 200-250 $\mathrm{g} \mathrm{C} \mathrm{m}^{2} \mathrm{yr}^{-1}$; Prentice et al., 2001).

While wetland vegetation takes up and stores carbon, its decomposition releases carbon dioxide $\left(\mathrm{CO}_{2}\right)$ and methane $\left(\mathrm{CH}_{4}\right)$. Methane production is promoted by saturated or flooded conditions in wetlands leading to limited oxygen availability for soil microbes and anaerobic decomposition (Whiticar, 1999). Wetlands play a dominant role in the global methane budget with a contribution estimated to be between 15 and $40 \%$ of the total source budget (Denman et al., 2007). Methane is an important greenhouse gas, with an estimated global radiative forcing of $0.48 \mathrm{~W} \mathrm{~m}^{-2}$ since the start of the Industrial Era (ca. 1750), roughly $30 \%$ that of $\mathrm{CO}_{2}(1.66$ $\mathrm{W} \mathrm{m}^{-2}$ ) (Denman et al., 2007). Although wetland $\mathrm{CH}_{4}$ influences climate, wetlands themselves are believed sensitive to climate changes and have been implicated in past changes in global atmospheric $\mathrm{CH}_{4}$ concentration following abrupt (Chappellaz et al., 1997; Brook et al., 2000; Huber et al., 2006) and glacial/interglacial climate changes (Loulergue et al., 2008). This apparent feedback between wetlands and climate has led global wetlands to be highlighted as an area of concern for potential large increases in $\mathrm{CH}_{4}$ emissions under future warming climates by the US Climate Change Science Program (CCSP, 2008). The CCSP (2008) report suggests that wetland modelling should aim to quantify the impact of climate changes on $\mathrm{CH}_{4}$ emissions, and to improve representation of wetland biogeochemistry, hydrology, and permafrost dynamics in both Earth system and global climate models, for a greater understanding of the risk this hypothesized positive climatic feedback poses. 
Wetland $\mathrm{CH}_{4}$ modelling began twenty-five years ago with Matthews and Fung (1987) combining vegetation, soil and fractional inundation maps, along with estimates of $\mathrm{CH}_{4}$ flux intensity, to generate a map of global wetland distribution and an estimate of wetland $\mathrm{CH}_{4}$ emissions. More processbased modelling of $\mathrm{CH}_{4}$ production, oxidation, and transport soon followed (Christensen and Cox, 1995; Christensen et al., 1996; Cao et al., 1996; Walter et al., 1996; Potter, 1997; Walter and Heimann, 2000), with much recent work devoted to improving these parameterizations (Segers and Leffelaar, 2001; van Bodegom and Goudriaan, 2001; van Bodegom et al., 2001; Zhuang et al., 2006) and using models to investigate the recent past (Ringeval et al., 2010; Hodson et al., 2011; Spahni et al., 2011), more distant past climates (Kaplan, 2002; van Huissteden, 2004; Valdes et al., 2005; Kaplan et al., 2006; Beerling et al., 2011; Hopcroft et al., 2011; Singarayer et al., 2011), and to project responses to future climate change (Shindell et al., 2004; Gedney et al., 2004; Bohn et al., 2007; Bohn and Lettenmaier, 2010; Ringeval, 2011).

Given the importance of accurately simulating global wetland $\mathrm{CH}_{4}$ emissions response to climate change, it is important to assess how well the models perform and to evaluate our current understanding. The WETland and wetland $\mathrm{CH}_{4}$ Inter-comparison of Models Project (WETCHIMP) was initiated to coordinate and facilitate the systematic study of wetland and wetland methane models for simulations of largescale wetland characteristics and corresponding $\mathrm{CH}_{4}$ emissions. To accomplish this goal, the project was designed around a standard set of simulations performed by each participating global or large-scale regional model. These simulations were run over the modern instrumental period because acceptable quality climate, observational data, topography, land cover, and soil data exist for this period. The standard simulations examined model responses to selective forcing inputs (such as precipitation, temperature, and atmospheric $\mathrm{CO}_{2}$ mixing ratios) to enable easier comparison between models. For full details of the modelling protocol, as well as a detailed analysis of the methodological differences between models, see Wania et al. (2012). The WETCHIMP participating models and simulations performed are described in Sect. 2. Model performance for wetland location determination is discussed in Sect. 3.1, wetland $\mathrm{CH}_{4}$ emissions in Sect. 3.2, and Sect. 3.3 discusses the sensitivity test results. The final section describes the project conclusions.

\section{Methods and participating models}

\subsection{Wetland definition}

For the purposes of regional- to global-scale modelling, wetlands are defined as grid cells, or fractions thereof, where the land surface has inundated, or saturated, conditions. The presence of the water table above, or close to the surface (on the order of centimetres), allows for anaerobic conditions to develop. Anaerobic conditions combined with decomposition of organic matter permits methanogenic $\mathrm{CH}_{4}$ production. Varying amounts of $\mathrm{CH}_{4}$ are emitted to the atmosphere dependent upon transport and consumption mechanisms as well as characteristics of a location such as vegetation present, plant root depth, water table position, and temperature. Following the National Wetlands Working Group (1988) classification, wetlands comprise three general types: peatlands (including bogs and fens), mineral wetlands (which includes swamps and marshes), and shallow water (National Wetlands Working Group, 1988).

Each wetland type has distinct characteristics. Peatlands have fixed extents, at least on timescales of decades, and contrasting hydrologic and nutrient regimes between dry nutrient-poor bogs and wet nutrient-rich fens. Mineral wetlands are dominated by vascular plants that facilitate $\mathrm{CH}_{4}$ transport through their roots and, along with shallow waters, strong interactions with water tables. These wetland types can be modelled explicitly or treated as a generic wetland type (where no distinction is made between the hydrologic regime, plant communities, and nutrient dynamics of the different wetlands); the latter is the general state of global wetland modelling with the exception of a few peatland specific models developed for the boreal region. LPJ-WHyMe, UWVIC, and LPJ-Bern (which embeds LPJ-WHyMe as a submodel) are the only participating models to model a wetland type (peatlands) explicitly (Bohn et al., 2007; Wania et al., 2009a,b; Bohn and Lettenmaier, 2010). Besides simulating peatlands and inundated areas, the LPJ-Bern model includes a unique parameterization of $\mathrm{CH}_{4}$ emissions from wet mineral soils. These areas are not wetlands, according to our definition as outlined above, but are argued to be an important source; they are simulated to emit low flux densities but over large areas (Spahni et al., 2011).

Generally excluded from consideration by large-scale wetland models are lakes, rivers, rice agriculture, saline estuaries, salt marshes, and reservoirs. The carbon, hydrologic, and anthropogenic management and plant community dynamics of these water bodies are considered to be distinct from those of natural wetlands. Saline systems, in particular, may involve processes that are missing in freshwater wetland models such as sulphate reduction (Bartlett et al., 1987). In practice however, the models are commonly not able to distinguish between wetlands and these other non-wetland water bodies; thus exclusion of these systems is commonly accomplished through masking of the grid cells with observational datasets (Table A1).

\subsection{Participating models and project simulations}

\subsubsection{Participating models}

This paper describes the first iteration of WETCHIMP. Ten models participated (Table 1), eight of which are global in 
Table 1. List of WETCHIMP participating models. Not all models contributed results to all experiments. The conceptualized, general description of net methane flux, $F$, by each model is adapted from Table 5 in Wania et al. (2012). This formulation is for illustrative purposes; thus the main variables and parameters used in $\mathrm{CH}_{4}$ production are detailed, but oxidation, $O$, and atmospheric oxidation, $O$ atm, are not. For all results presented in this paper, all $O_{\text {atm }}$ values were set to 0 , allowing comparison of modelled gross fluxes. All variables listed are described in the table footnotes. Note that identical parameters/variables for different models do not imply identical values used in the models. A full listing of contributed experiments and model set-ups for the experiments, as well as greater detail on the models' methane flux parameterizations, is provided in Wania et al. (2012).

\begin{tabular}{|c|c|c|c|c|c|}
\hline Model & $\begin{array}{l}\text { Resolution } \\
\text { (long. × lat.) }\end{array}$ & Coverage & Wetland determination scheme & $\begin{array}{l}\mathrm{CH}_{4} \text { flux parameterization } \\
\text { (see table footnotes) }\end{array}$ & Principal references \\
\hline CLM4Me & $2.5^{\circ} \times 1.9^{\circ}$ & Global & $\begin{array}{l}\text { Model-simulated runoff and water table } \\
\text { depth used in diagnostic equation that was } \\
\text { parameterized for best fit to the GIEMS } \\
\text { dataset. }\end{array}$ & $\begin{array}{l}F= \\
\left(R_{\mathrm{het}} r_{\mathrm{CH} 4: \mathrm{C}} f_{\mathrm{pH}} f_{\mathrm{pE}} Q_{10}-\right. \\
O) f_{\text {transport }}-O_{\mathrm{atm}}\end{array}$ & Riley et al. (2011) \\
\hline DLEM & $0.5^{\circ} \times 0.5^{\circ}$ & Global & $\begin{array}{l}\text { Maximal extents from inundation dataset } \\
\text { with simulated intra-annual dynamics. }\end{array}$ & $\begin{array}{l}F=\left(P_{\mathrm{max}} \mathrm{C}_{\text {labile }} f_{T} f_{\mathrm{pH}} f_{\Theta}-\right. \\
\left.O_{\text {trans }}-O_{\text {soil }}\right) f_{\text {transport }}-O_{\mathrm{atm}}\end{array}$ & $\begin{array}{l}\text { Tian et al. (2010, 2011); Xu } \\
\text { and Tian (2012) }\end{array}$ \\
\hline IAP-RAS & $0.5^{\circ} \times 0.5^{\circ}$ & Global & $\begin{array}{l}\text { Prescribed extents from land cover dataset } \\
\text { (CDIAC NDP017). }\end{array}$ & $F=f_{T} f_{\Theta} Q_{10}$ & $\begin{array}{l}\text { Mokhov et al. (2007); Eliseev } \\
\text { et al. (2008) }\end{array}$ \\
\hline LPJ-Bern & $0.5^{\circ} \times 0.5^{\circ}$ & Global & $\begin{array}{l}\text { Prescribed peatlands and monthly inunda- } \\
\text { tion. Simulated dynamic wet mineral soils } \\
\text { (saturated, non-inundated). }\end{array}$ & $\begin{array}{l}\text { Peat: } \\
F=\left(R_{\text {het }} r_{\mathrm{CH} 4: \mathrm{C}} f_{\text {root }} f_{\mathrm{WTP}}-\right. \\
O) f_{\text {transport Wetlands: } F=} F= \\
R_{\text {het }} r_{\mathrm{CH} 4: \mathrm{C}} \text { Wet soils: } F= \\
R_{\text {het }} r_{\mathrm{CH} 4: \mathrm{C}} f_{\Theta}-O_{\text {atm }}\end{array}$ & Spahni et al. (2011) \\
\hline LPJ-WHyMe & $0.5^{\circ} \times 0.5^{\circ}$ & $\begin{array}{l}\text { Peatlands } \\
\left(>35^{\circ} \mathrm{N}\right)\end{array}$ & $\begin{array}{l}\text { Prescribed peatland extents (Tarnocai et al., } \\
\text { 2009) with simulated saturated/unsaturated } \\
\text { conditions. }\end{array}$ & $\begin{array}{l}F=\left(R_{\text {het }} r_{\mathrm{CH} 4: \mathrm{C}} f_{\text {root }} f_{\mathrm{WTP}}-\right. \\
O) f_{\text {transport }}\end{array}$ & Wania et al. (2009a,b, 2010) \\
\hline LPJ-WSL & $0.5^{\circ} \times 0.5^{\circ}$ & Global & Prescribed from monthly inundation dataset. & $F=R_{\text {het }} r_{\mathrm{CH} 4: \mathrm{C}} f_{\text {ecosys }}$ & Hodson et al. (2011) \\
\hline ORCHIDEE & $1.0^{\circ} \times 1.0^{\circ}$ & Global & $\begin{array}{l}\text { Mean yearly extent over } 1993-2004 \text { period } \\
\text { scaled to that of inundation dataset with } \\
\text { model calculated intra- and inter-annual dy- } \\
\text { namics. }\end{array}$ & $\begin{array}{l}F= \\
\left(R_{0} \mathrm{C}_{\text {labile }} f_{\mathrm{WTP}} f_{T} Q_{10}-\right. \\
O) f_{\text {transport }}\end{array}$ & $\begin{array}{l}\text { Ringeval et al. (2010, 2011) } \\
\text { Ringeval (2011) } \\
\text { Ringeval et al. (2012) }\end{array}$ \\
\hline SDGVM & $0.5^{\circ} \times 0.5^{\circ}$ & Global & Independently simulated extents. & $\begin{array}{l}F= \\
R_{\text {het }} r_{\mathrm{CH} 4: \mathrm{C}} f_{\mathrm{WTP}} f_{T} Q_{10}-O\end{array}$ & $\begin{array}{l}\text { Hopcroft et al. (2011) } \\
\text { Singarayer et al. (2011) }\end{array}$ \\
\hline UVic-ESCM & $3.6^{\circ} \times 1.8^{\circ}$ & Global & Independently simulated extents. & & Avis et al. (2011) \\
\hline UW-VIC & $100 \mathrm{~km} *$ & $\begin{array}{l}\text { W. Siberian } \\
\text { lowlands }\end{array}$ & $\begin{array}{l}\text { Prescribed peatland extents with inundation } \\
\text { dataset dynamics modulated by internally } \\
\text { calculated saturated/unsaturated conditions. }\end{array}$ & $\begin{array}{l}F=\left(R_{0} f_{\mathrm{NPP}} f_{\text {root }} f_{T} Q_{10}-\right. \\
O) f_{\text {transport }}\end{array}$ & $\begin{array}{l}\text { Bohn et al. (2007); Bohn and } \\
\text { Lettenmaier (2010) }\end{array}$ \\
\hline
\end{tabular}

extent with two additional models specific to smaller regions (LPJ-WHyMe and UW-VIC). One model, UVic-ESCM, simulates the global wetland area but does not presently contain a parameterization for methane emissions. The general UW-VIC model set-up is described here, but a detailed treatment of UW-VIC's results will be discussed in a follow-up paper (Bohn et al., 2013). Of the participating models, there is a large variation in complexity and how comprehensive the models have attempted to be in characterizing wetland extent and $\mathrm{CH}_{4}$ emission processes.

The participating models use three general approaches for determining wetland areal extents: prescribed extents, parameterization/forcing with a remotely sensed inundation dataset, or independent wetland location determination via the model's hydrological model. Models with prescribed extents include LPJ-WHyMe (peatlands), LPJ-Bern (peatlands), IAP-RAS (global wetlands), and UW-VIC (peatlands). Models that used a remotely sensed inundation dataset include CLM4Me, DLEM, ORCHIDEE, LPJ-Bern, UW-VIC, and LPJ-WSL. To ensure inter-comparability, these six models used the Global Inundation Extent from Multi-Satellites (GIEMS) dataset (Prigent et al., 2007; Papa et al., 2010) (Fig. 1d). Two models, SDGVM and UVicESCM, used solely their internal hydrological model to determine wetland locations. Masking of rice agriculture areas, large lakes, and large rivers was done by several models (Table A1).

The models that used the GIEMS dataset to aid determination of wetland location adopted different procedures. CLM4Me used the GIEMS dataset from 1993-2000 (as reported in Prigent et al., 2007) to constrain a diagnostic inundated fraction that is used for $\mathrm{CH}_{4}$ and $\mathrm{O}_{2}$ reaction transport. The water table in the diagnostic fraction is either model-generated or at the surface. DLEM limits their simulated annual maximal wetland extent to the GIEMS dataset but independently simulates intra-annual wetland dynamics. The mean simulated wetland areal extent of ORCHIDEE is scaled to match that of the GIEMS dataset, with simulated intra- and inter-annual variability otherwise unchanged from the model's TOPMODEL-based 
approach (Beven and Kirkby, 1979). LPJ-WSL directly used the GIEMS dataset to determine wetland extent.

The $\mathrm{CH}_{4}$ emission parameterizations embedded within the models also have varying levels of complexity. The models use wetland (DLEM, UW-VIC, LPJ-Bern - peatlands, and LPJ-WHyMe) and/or upland (CLM4Me, DLEM, SDGVM, LPJ-Bern - non-peatlands, LPJ-WSL, ORCHIDEE, IAPRAS) plant functional types (PFTs) to estimate NPP. The PFT fractional cover is either prescribed (ORCHIDEE, IAP-RAS, CLM4Me, UW-VIC) or determined dynamically within the model (LPJ-Bern, LPJ-WHyMe, LPJ-WSL, SDGVM, DLEM, UVic-ESCM). Most models then relate $\mathrm{CH}_{4}$ emissions to NPP with the exception of IAP-RAS. IAPRAS has a simple methane parameterization that is sensitive to temperature, but considers carbon substrates to be non-limiting in wetlands. Due to the simplicity of its approach, IAP-RAS is applicable only for annual $\mathrm{CH}_{4}$ fluxes. In other models, relating NPP to $\mathrm{CH}_{4}$ emissions is done via production of exudates or litter and soil carbon to yield heterotrophic respiration estimates (Table 1). A proportion of the heterotrophic respiration estimate is then taken to be $\mathrm{CH}_{4}$ production. Some models explicitly simulate oxidative loss during transport of the $\mathrm{CH}_{4}$ from site of production to the atmosphere (CLM4Me, LPJ-Bern - peatlands, LPJ-WHyMe, and UW-VIC) or assign a fixed proportion of loss (LPJWSL, SDGVM, LPJ-Bern - non-peatlands, ORCHIDEE, DLEM, and IAP-RAS). A few models also simulate aerobic soil uptake of $\mathrm{CH}_{4}$ from the atmosphere (CLM4Me, DLEM, and LPJ-Bern). The WETCHIMP results presented here are simulated gross wetland $\mathrm{CH}_{4}$ emissions (thereby excluding soil uptake of atmospheric $\mathrm{CH}_{4}$ in both wetland and upland ecosystems). The full differences between the models' wetland and $\mathrm{CH}_{4}$ production schemes are described in detail in Wania et al. (2012).

\subsubsection{Project simulations}

Six experiments were performed for WETCHIMP. The suite of experiments were designed to investigate model performance under transient conditions, as well as equilibrium state simulations with step changes in climate forcing. The first experiment was an equilibrium simulation under a repeating 1901-1931 climate and a carbon dioxide concentration $\left(\left[\mathrm{CO}_{2}\right]\right)$ of $303 \mathrm{ppm}$. The second experiment was a transient simulation from 1901-2009 using observed climate and $\left[\mathrm{CO}_{2}\right]$ values (all datasets used and full experiment details are described in Wania et al., 2012). One exception to the project protocol was CLM4Me, which kept a constant $\left[\mathrm{CO}_{2}\right]$ across the simulation period of Experiment 2 ( $303 \mathrm{ppm})$. The comparison period of 1993-2004 was chosen due to the overlap with the GIEMS dataset, allowing the models that require an inundation dataset to be forced with observed values. A third experiment was run with similar constraints as the second experiment, but the models were allowed to run in user-defined optimal conditions (Wania et al., 2012). The third experiment allowed participants to investigate the impact of using their optimized forcing data for comparison against the results of Experiment 2. Since Experiment 2 allows for better inter-comparability between the models, all transient results presented here are from Experiment 2.

From each model's equilibrium state (Experiment 1) (Fig. A1), model atmospheric $\left[\mathrm{CO}_{2}\right]$ was instantaneously increased to 857 ppm (SRES A2 year 2100 levels IPCC, 2000, Experiment 4). The simulation was then run until the model had reached a new equilibrium state (number of years was model dependent). Experiment 5 investigated the effect of an instantaneous increase of $+3.4^{\circ} \mathrm{C}$ in surface air temperature (SAT). The magnitude of this $+3.4{ }^{\circ} \mathrm{C}$ increase was taken from the SRES A2 year multi-model mean SAT warming for 2090 to 2099 relative to 1980 to 1999 (Meehl et al., 2007). However, in our simulations this $+3.4{ }^{\circ} \mathrm{C}$ increase was applied to the mean climate of 1901-1931, and not to 1980-1999, thus causing a slightly smaller influence than it would have had against the climate of 1980-1999. The final experiment (\#6) examined model response to changes in precipitation with an instantaneous increase of $+3.9 \%$ (SRES A2 2100 level; $30 \mathrm{yr}$ global average for 2071-2100 relative to 1961-1990) (Prentice et al., 2001). Both the SAT and precipitation sensitivity tests were applied to all months and grid cells uniformly. While the magnitudes of the step increases were chosen to be of a similar magnitude to projected future climate changes, the uniform application of these changes is unrealistic but suitable for the purpose of the sensitivity tests, where we are most interested in the relative responses from the models rather than projecting absolute responses to future climate changes. Step changes were adopted, rather than transient simulations, to allow for simpler interpretation of the results and the differences between model responses. For statistical analysis of the model results, all Spearman correlation coefficients and percentile distributions (quantile function, type $=8,5 \%, 25 \%, 75 \%$, and $95 \%$ distributions) were calculated using the R statistical package (v. 2.10.1).

\subsubsection{Wetland observational datasets}

Observational datasets of wetlands are used to both parameterize and evaluate wetland $\mathrm{CH}_{4}$ models. The observational datasets presently available fall into two main categories: remotely sensed inundation datasets (such as GIEMS; Prigent et al., 2007; Papa et al., 2010, or Schroeder et al., 2010) and wetland and land cover mapping products (including MODIS: ORNL DAAC, 2000, Lehner and Döll, 2004; and Kaplan 2007 in Bergamaschi et al., 2007). In this study, we have compared the simulated wetland extent to two observationally based datasets. The first dataset is the remotely sensed inundation product, GIEMS (Prigent et al., 2007; Papa et al., 2010), and the second is the Kaplan 2007 wetland mapping product (hereafter referred to as K07) (Fig. 1c), which was originally presented and described in Bergamaschi et al. (2007). Each dataset has 


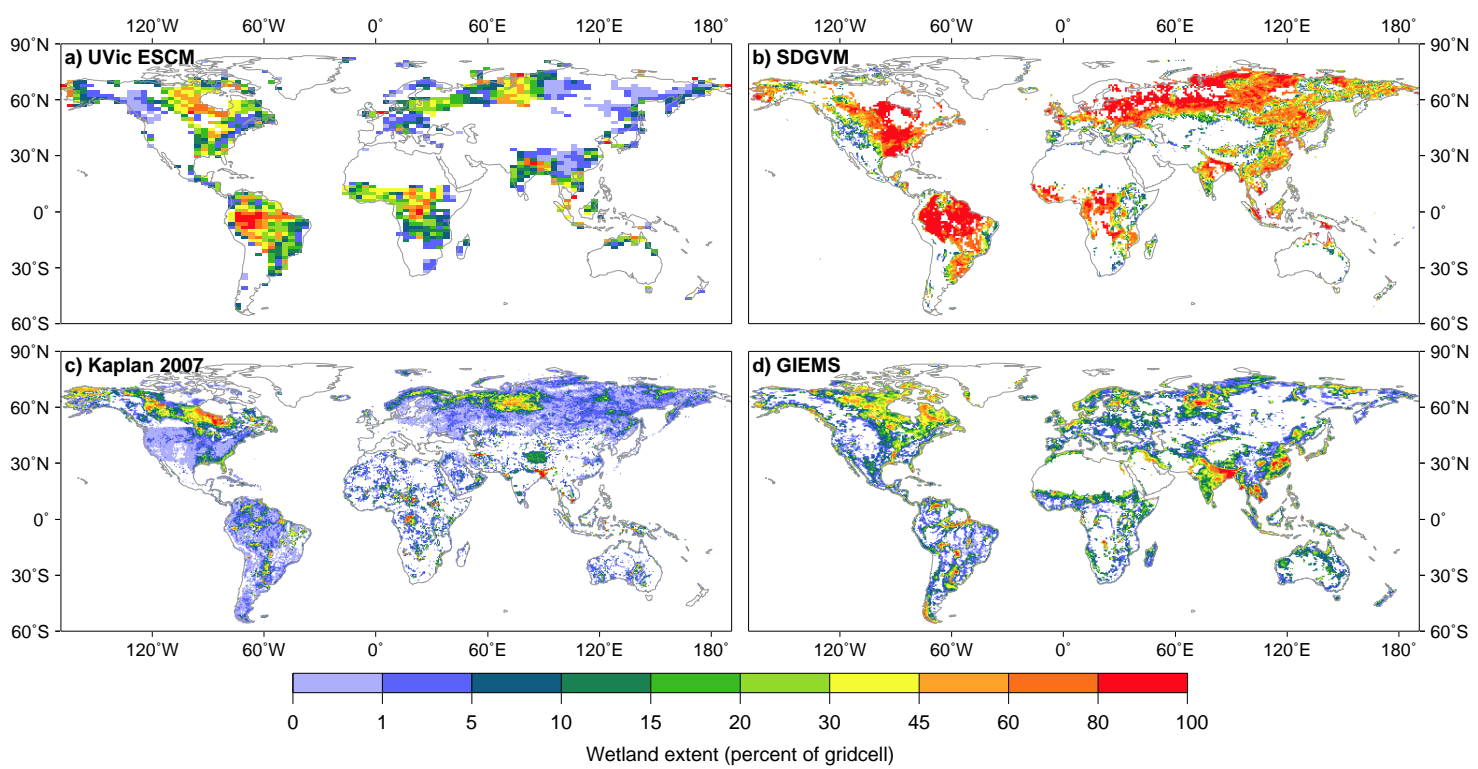

Fig. 1. Simulated mean annual maximal wetland extent for 1993-2004. The SDGVM and UVic-ESCM model results are from Experiment 2-Transient. The GIEMS inundation dataset is plotted as the mean annual maximum value across all years (1993-2004).

particular strengths and weaknesses for application in wetland modelling studies.

Wetland mapping products like K07 and GLWD-3 (Lehner and Döll, 2004) are based on aggregating regional and global wetland and land cover maps. Wetland mapping products have the advantage of only selecting wetlands for inclusion, excluding other water bodies like lakes and rice agriculture. However, they also might overestimate some wetlands, such as in arid or semiarid regions where intermittent wetlands' frequency of turning into actual wetlands could be extremely rare (Lehner and Döll, 2004). These mapping products are also static in time, not allowing for seasonal dynamics, and could be outdated given that wetland ecosystems are highly impacted by humans. For example, it is roughly estimated that up to half of the world's wetlands have been drained for disease vector control or agriculture, at a rate that has increased in recent times, making it difficult for the map production to keep pace (Dugan, 1993). Remotely sensed inundation datasets, such as GIEMS, have the advantage of being more up-to-date, allowing at least monthly resolution, and have close to global coverage. Problems with the use of these datasets for wetland modelling relates to the non-specific measurement of inundation, i.e. no information about depth of water ponding; ambivalence to type of water body (thus necessitating masking of non-wetlands); and presently available datasets are limited to detecting standing water at the surface. Given that many wetlands will continue to produce $\mathrm{CH}_{4}$ at depth even if there is no standing water, detection of saturated, non-inundated conditions is also important.

Before we use these two datasets to evaluate simulated wetland extents, we should note there is a fair amount of discrepancy between the inundation (GIEMS; Fig. 1d) and the wetland mapping (K07; Fig. 1c) datasets that complicates our evaluation. The major areas of disagreement are around Labrador and Nunavut in the Canadian Arctic (GIEMS shows more wetlands), the Hudson Bay Lowlands (HBL) (K07 shows more wetlands), and in Europe (GIEMS shows extensive inundation while K07 shows few wetlands). As well, both GIEMS and K07 show relatively small wetland extents in the humid tropics. These characteristics of the datasets appear to be related to four main issues.

First, in boreal and Arctic Canada, the GIEMS inundation dataset appears to detect the many small lakes present and classify these as inundated land (Walker et al., 2005). While correct in principle, these areas are not commonly defined as wetlands due to the differing hydrologies, carbon dynamics, and plant communities. Thermokarst lakes are an important example of a lake system that produces methane from carbon sources and processes distinct from those of arctic wetland complexes (Walter Anthony et al., 2008; van Huissteden et al., 2011) and would not be adequately captured if modelled as a wetland system. Thus, while it is perhaps reasonable for an inundation dataset to not distinguish small lakes from wetlands if the dataset is principally designed to detect standing water, this has important implications for the use of these datasets for wetland simulations. These lakes are explicitly not included in the K07 wetland mapping dataset.

Second, the extensive peatland complexes of the HBL are not adequately resolved by the inundation dataset, as many of these areas have a high water table that is below the peatland surface, but retain saturated conditions and the ability to produce $\mathrm{CH}_{4}$ at depth (Bellisario et al., 1999). In the 
West Siberian Lowlands, the GIEMS dataset gives higher inundation values in non-forested regions, and lower values in forested regions, than another remotely sensed dataset (Schroeder et al., 2010). For this region, after comparison with high-resolution Phased-Array L-Band Synthetic Aperature Radar (PALSAR), it appears GIEMS underestimates inundation in forested areas in this region (T. Bohn, personal communication, 2012).

Third, Europe appears to have large inundated areas in the GIEMS dataset, but very few wetlands with the K07 dataset. Many of these inundated areas could be flooded agricultural fields and not actual wetland complexes. Given the population density and well-mapped nature of Europe, it is unlikely that the wetland mapping products are greatly in error.

Finally, both the inundation and wetland mapping datasets appear to be missing large areas of wetlands in the humid tropics. The presence of these wetlands can be inferred from SCIAMACHY satellite data indicating wide-spread high $\mathrm{CH}_{4}$ emissions in the tropics, e.g. over the Amazon region (Frankenberg et al., 2008). Aerobic $\mathrm{CH}_{4}$ production from plants appears to be a minor source (Houweling et al., 2006; Kirschbaum et al., 2006; Ferretti et al., 2007), thus the dominant source of the $\mathrm{CH}_{4}$ should be saturated soils or wetlands. For example, Miller et al. (2007) estimated wetlands to emit around $70 \%$ of total $\mathrm{CH}_{4}$ emissions in eastern Amazonia, yet the GIEMS dataset shows relatively little inundated area in the region. Other indirect evidence comes from the GIEMS dataset's high inundation reported along the northern Saharan vegetation border in Africa, dropping off rapidly inside the tropical forest cover (Fig. 1d). The remotely sensed GIEMS datasets could have difficulty detecting inundated areas under the dense forest canopies of the region (similar to the low inundation reported in the West Siberian Lowlands, as discussed earlier). While Prigent et al. (2007) state that the remote sensing approach allows for penetration of the vegetation to a certain extent, it is possible that the dense canopy of the tropical regions does not allow adequate penetration of the microwave emissivities and backscatter coefficients. Wetland mapping datasets, like K07, rely upon land surveys to determine the land cover type - an approach possibly hampered by sparse or incomplete information for remote regions.

Problems of consistency and accurate coverage are not limited to the K07 and GIEMS datasets, as other wellknown datasets are also problematic. The Matthews and Fung (1987) dataset has been used in several forward and inverse $\mathrm{CH}_{4}$ modelling studies (Fung et al., 1991; Cao et al., 1996; Hein et al., 1997). The Matthews and Fung (1987) dataset has been suggested to be poorly suited for modelling of wetland $\mathrm{CH}_{4}$ emissions as the dataset contains salt marshes (similar to GLWD-3; Lehner and Döll, 2004) and denotes wetlands based on indirect criteria (soils, vegetation and inundation) (Sanderson, 2001). Additionally, the Matthews and Fung (1987) dataset has been shown (Sanderson, 2001) to be missing large areas of wetlands that are documented in other databases such as the Ramsar database (Wetlands International, 2002), a deficiency shared with other databases including Cogley (1994) and GLCC (Loveland et al., 2000). On a regional scale, remote peatland regions appear to be problematic for both wetland mapping and inundation datasets as reported by Frey and Smith (2007) . They collected field ground cover observations over an area of $\sim 10^{6} \mathrm{~km}^{2}$ in West Siberia and compared them to four remotely sensed datasets and wetland mapping products for permanent wetlands, finding an agreement of only between 2 and $56 \%$, depending on the dataset (although it should be noted that neither K07 nor GIEMS was part of their comparison) (Frey and Smith, 2007).

Table 2 shows a three-fold difference between various observational-based estimates of global wetland area; some of this difference can be related to earlier estimates not including transient wetlands (Lehner and Döll, 2004), however the magnitude and spatial differences between datasets remains large and presents difficulties for appropriate parameterization of wetland models, and evaluation of model outputs.

\section{Results and discussion}

\subsection{Wetland areal extent}

\subsubsection{Maximal wetland areal extent}

The mean annual maximal wetland extent was calculated for the models over the period 1993-2004 for Experiment 2 (see Sect. 2 for description), correlating to the same time period as the GIEMS dataset. The K07 dataset possibly contains some wetlands mapped over that same time period but is composed primarily of wetlands mapped during earlier periods. The results for the SDGVM and UVic-ESCM models, the only models that are not parameterized with an inundation dataset or prescribed extents, and the K07 and mean annual maximal wetland areal extent of GIEMS are shown in Fig. 1.

Looking first at the overall pattern of modelled maximal wetland extent, the SDGVM model generally simulates greater wetland area than UVic-ESCM along with higher saturation of wetlands in grid cells with wetland cover. For both models there is a tendency for large areas to be simulated as almost $100 \%$ wetland cover (though the grid cell size of UVic-ESCM is larger at $3.6^{\circ} \times 1.8^{\circ}$ compared to $0.5^{\circ} \times 0.5^{\circ}$ for SDGVM), which is not apparent in the wetland mapping and inundation datasets.

Regionally, SDGVM simulates more wetland area than UVic-ESCM across large areas of the Eastern US and Eastern Eurasia. The greatest similarity in modelled wetland extents is for the western Amazon and Congo regions, with both models showing large areas of high wetland extents (approaching $100 \%$ of grid cell area). Both models show little wetlands in normally arid regions like Central Australia, 
Table 2. Mean annual maximum wetland extent for participating models over the period 1993-2004 (Experiment 2-Transient). For a description of how each model determines wetland extent, see Table 1 and Wania et al. (2012). GLCC is the USGS Global Land Cover Characteristics database (Loveland et al., 2000). MODIS is the MODerate resolution Imaging Spectroradiometer land cover product (ORNL DAAC, 2000). Some of the observational estimates do not include transient wetlands (GLCC \& MODIS), and are not specific to the 1993-2004 period with the exception of the GIEMS dataset.

\begin{tabular}{|c|c|c|c|}
\hline Model & $\begin{array}{l}\text { Global } \\
\left(10^{6} \mathrm{~km}^{2} \pm 1 \sigma\right)\end{array}$ & $\begin{array}{l}\text { Tropics }\left(30^{\circ} \mathrm{S}-30^{\circ} \mathrm{N}\right) \\
\left(10^{6} \mathrm{~km}^{2} \pm 1 \sigma\right)\end{array}$ & $\begin{array}{l}\text { Extratropics }\left(>35^{\circ} \mathrm{N}\right)^{\mathrm{a}} \\
\left(10^{6} \mathrm{~km}^{2} \pm 1 \sigma\right)\end{array}$ \\
\hline CLM4Me & $8.8 \pm 1.5$ & $2.6 \pm 0.2$ & $5.1 \pm 1.4$ \\
\hline DLEM & $7.1 \pm 1.1$ & $3.1 \pm 0.4$ & $3.3 \pm 0.8$ \\
\hline IAP-RAS & 20.3 & 1.3 & 18.9 \\
\hline LPJ-Bern ${ }^{\mathrm{a}}$ & $81.7 \pm 2.4$ & $38.8 \pm 1.8$ & $36.4 \pm 2.8$ \\
\hline & $(7.9 \pm 0.8)^{\mathrm{b}}$ & $(2.7 \pm 0.2)^{b}$ & $(4.5 \pm 0.6)^{b}$ \\
\hline LPJ-WHyMe & $2.7^{\mathrm{c}}$ & n.a. & $2.7^{\mathrm{c}}$ \\
\hline LPJ-WSL & $9.0 \pm 1.1$ & $3.8 \pm 0.3$ & $4.2 \pm 0.9$ \\
\hline ORCHIDEE & $8.6 \pm 0.9$ & $4.3 \pm 0.3$ & $3.4 \pm 0.7$ \\
\hline SDGVM & $26.9 \pm 3.6$ & $13.2 \pm 1.1$ & $12.0 \pm 3.8$ \\
\hline UVic-ESCM & $16.3 \pm 1.4$ & $10.6 \pm 0.4$ & $5.0 \pm 1.2$ \\
\hline \multicolumn{4}{|l|}{ Observational estimates: } \\
\hline Matthews and Fung (1987) & 5.3 & & \\
\hline Williams $(1991)^{\mathrm{d}}$ & 8.6 & & \\
\hline Cogley (1994) & 4.3 & & \\
\hline Stillwell-Soller et al. (1995) & 4.8 & & \\
\hline $\mathrm{GLCC}^{\mathrm{d}}$ & 10.9 & & \\
\hline MODIS $^{d}$ & 12.9 & & \\
\hline Finlayson et al. (1999) & $\min .12 .8$ & & \\
\hline Mitsch and Gosselink (2000) ${ }^{\mathrm{d}}$ & $7.0-9.0$ & & \\
\hline GLWD-3 in Lehner and Döll (2004) & 9.2 & & \\
\hline Gross wetlands map in Lehner and Döll (2004) $)^{\mathrm{e}}$ & 11.7 & & \\
\hline K07 in Bergamaschi et al. (2007) & 6.2 & 2.8 & 2.8 \\
\hline GIEMS $^{\mathrm{f}}$ & $12.6 \pm 0.8$ & $6.0 \pm 1.4$ & $5.2 \pm 1.2$ \\
\hline
\end{tabular}

a This includes the area of wet mineral soils in addition to peatlands and masked inundated areas.

$\mathrm{b}$ This includes only the masked inundated areas and peatlands.

c The LPJ-WHyMe model considers only northern peatlands.

d As summarized in Lehner and Döll (2004).

e This estimate is derived in Lehner and Döll (2004) as the maximum wetland area per grid cell in either Matthews and Fung (1987), Cogley (1994),

Stillwell-Soller et al. (1995), GLCC, or MODIS.

${ }^{\mathrm{f}}$ The GIEMS inundation dataset has not had any masking applied. Removing areas of rice agriculture gives the same magnitude of extent as LPJ-WSL.

the Western US, western South Africa, and desert regions. The eastern Canadian Arctic $\left(>65^{\circ} \mathrm{N}\right)$ differs between the models with UVic-ESCM simulating much higher wetland extents than SDGVM and with an opposite pattern in Eastern Siberia with more wetlands simulated by SDGVM than UVic-ESCM. These high latitude differences are likely due to the model treatment of permafrost and soil freezing. UVicESCM has fully dynamic permafrost regions with freezing and thawing of soil layers, which influence soil hydrology. Conversely, SDGVM has relatively simple precipitationevaporation/water table functions that do not allow freezing of the soil water. Both of these models, and indeed all models in WETCHIMP, do not have lateral flow of water between grid cells, which limits their ability to simulate hydrologic conditions in regions where large contributions of water flow into a region from upland areas via rivers into floodplains.
The overall pattern of wetland locations for the UVicESCM model compares well to the K07 dataset, with the exception of more wetlands in Eastern Europe and much more in the Congo for UVic-ESCM. Comparing UVic-ESCM to the GIEMS dataset shows reasonable general agreement with the exception of greater wetland extents in Eastern Siberia and Southern Australia in the GIEMS dataset. For SDGVM, while it simulates a larger wetland extent globally, there are some areas where SDGVM simulates less wetlands than the observational datasets. Two examples include Scandinavia, which has more wetlands in both GIEMS and K07, and the Canadian areas of Labrador and Nunavut, which appear prominently in the GIEMS dataset, but not in the K07 dataset. Both of these higher latitude sites could be poorly resolved by SDGVM due to its simple soil model and inability to simulate permafrost. 
Comparing maximal wetland extent modelled by SDGVM and UVic-ESCM with the observational datasets shows a general tendency of these models to estimate relatively large global wetland extents (Table 2). UVic-ESCM has a larger tropical wetland area than subtropical, while SDGVM has more similar extents. The other models are about evenly split with almost half the models simulating a larger extratropical wetland area, and the other half simulating a larger tropical wetland area (Table 2). The observational datasets, K07 and GIEMS, give maximal wetland extents of $6.2 \times 10^{6}$ and $12.6 \times 10^{6} \mathrm{~km}^{2}$, respectively, with both datasets showing similar wetland extents in the extratropics and tropics. SDGVM simulates a global wetland area of $26.9 \times 10^{6} \mathrm{~km}^{2}$ and UVic-ESCM simulates $16.9 \times 10^{6} \mathrm{~km}^{2}$. Previous observationally based studies would suggest that global wetland extent is in the range of $6-13 \times 10^{6} \mathrm{~km}^{2}$ (Table 2), possibly in the upper part of that range (Lehner and Döll, 2004). The apparent overestimate of wetland extents by SDGVM is a result of the binary nature of its wetland determination scheme. This overestimate will not necessarily carry over into its estimated $\mathrm{CH}_{4}$ emissions, as once a wetland grid cell is identified by SDGVM, the $\mathrm{CH}_{4}$ emissions are calculated using simulated water table position (WTP), not wetland area, and are corrected for sub-grid orography. Some of the UVicESCM model's overestimation could be due to the model being parameterized to the internal UVic-ESCM-modelled climate, with its associated biases, and not to the observed climate used in this inter-comparison. As well, UVic-ESCM uses only two parameters to define wetland locations: soil moisture and slope. It appears that this simple approach results in overestimated wetland extent in regions not influenced by permafrost dynamics, which is where the model was originally intended to be applied (Avis et al., 2011).

The other models participating in WETCHIMP either have static wetland extents (IAP-RAS and LPJ-WHyMe) or have been parameterized to yield a similar magnitude of annual wetland extent to the GIEMS dataset (Table 2). One other model, LPJ-Bern, has a wetland extent considerably higher than K07 and GIEMS. The wet mineral soils parameterization of LPJ-Bern results in very large areas of wet mineral soils, non-inundated water saturated regions, that are assumed capable of $\mathrm{CH}_{4}$ production. This large area $(81.7 \times$ $10^{6} \mathrm{~km}^{2}$ ) is not readily comparable to the other models, or the observational datasets, and is unique to LPJ-Bern. This "wet mineral soils" source should not be confused with "mineral wetlands", a wetland type identified by the National Wetlands Working Group (1988) as described in Sect. 2.1.

\subsubsection{Inter- and intra-annual variability of wetland areal extent}

Simulated changes in wetland areal inter- and intra-annual extent are compared for the period 1993-2004 for six models in Fig. 2 (SDGVM, UVic-ESCM, CLM4Me LPJ-Bern, DLEM and ORCHIDEE). The GIEMS dataset, without any masking for lakes and rice agriculture applied, is included in the normalized plot (Fig. 2g) for comparison against an observational dataset, with the caveats as described in Sect. 2.2.3, and the additional consideration that the GIEMS dataset represents inundated area, which is not necessarily the same as wetland area. It is assumed that the temporal pattern of inundated area is likely to correspond reasonably with the temporal pattern of wetland area (see wetland definition in Sect. 2.1). The K07 dataset can not be used here for comparison as it is a static distribution. A discussion of each model's simulated changes in wetland areal extents is included in Appendix A1.

If the GIEMS inundation dataset is assumed to be an accurate proxy for global wetland area, the models that most closely, on average, reproduce its annual cycle are CLM4Me and SDGVM, and to a lesser extent DLEM. The relative difference between maximum and minimum global wetland extents for the GIEMS dataset is much larger than LPJ-Bern and UVic-ESCM results, again more in line with CLM4Me and SDGVM, and to a lesser extent DLEM. The model distribution (grey area in Fig. 2g) shows that, on average, the models simulate an earlier peak in wetland extent than the inundated area peak in the GIEMS dataset, outside of the models' 5 th percentile distribution for the months of May and June. If it is correct that the GIEMS dataset is underestimating inundated area in the tropics as suggested earlier, global wetland extent from GIEMS would be biased to the northern high latitudes. This could cause a later peak in global wetland extent as the region is slow to lose snow cover and allow inundation to develop.

Papa et al. (2010) found a $\sim 5.7 \%$ reduction in mean annual maximum inundation across the 1993-2004 period, located mostly in the tropics. This reduction is not evident in the models' results (see Figs. 2 and 7), with the exception of DLEM whose annual maximum is prescribed to be the same as the GIEMS dataset. The lack of trend in the simulated wetland extents could be due to several possible reasons: (1) the models are inadequately simulating inundation and saturated conditions, (2) modelled wetland extent, which can include both saturated/inundated and unsaturated areas (model dependent, see Wania et al., 2012), does not correlate to inundated area, (3) the assumption that wetland area is proportional to inundated area is false, (4) the models' inability to laterally transfer water between grid cells produces erroneous lowland wetland extents, and (5) the trend observed in the GIEMS dataset is due to artefacts in data retrieval and processing although the decrease in global extent occurred primarily in the 1990s, the years of the GIEMS record with the highest confidence (Papa et al., 2010).

Zonal sums of the mean annual maximal wetland extent for all models show relatively poor agreement between the models (Fig. 3). The area of best agreement is the high northern latitudes (north of $45^{\circ} \mathrm{N}$ ). CLM4Me predicts a prominent peak in wetland extent above $60^{\circ} \mathrm{N}$. These wetlands form in CLM4Me due to impeded drainage on frozen soils 

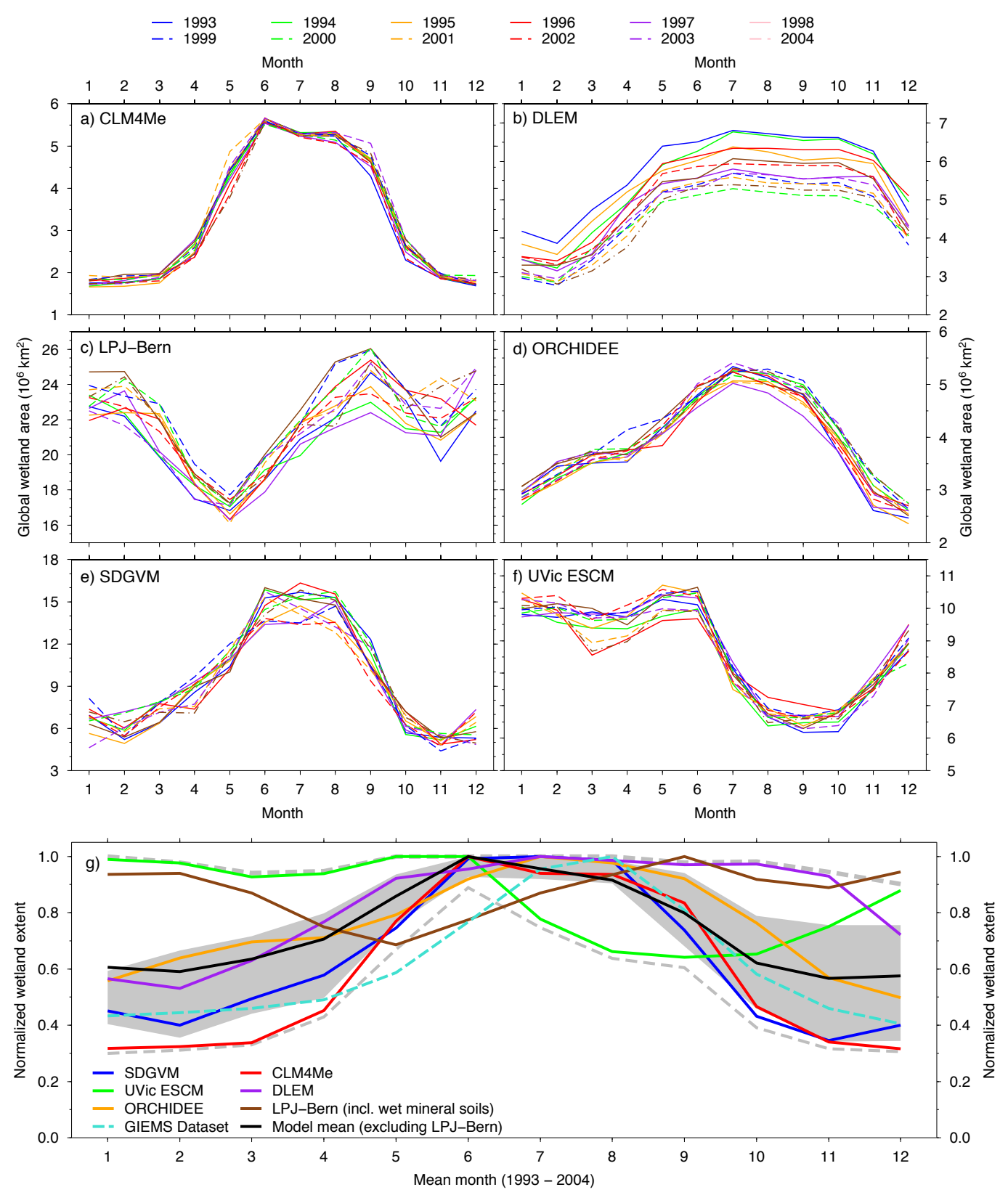

Fig. 2. Monthly global wetland extent for 1993-2004 for all models that do not use an external dataset for calculation of intra- and/or interannual variability. Plot (g) is the normalized monthly global wetland extent for all models in plots (a)-(f), the unaltered GIEMS inundation dataset, as well as the mean extent of the models (excluding LPJ-Bern due to its wet mineral soils parameterization). The grey shading denotes the 25th and 75th percentiles of the model distribution (excluding LPJ-Bern). The grey dashed lines are the 5th and 95th percentiles.

(Riley et al., 2011). SDGVM has a much larger boreal peak than the other models as a result of its simple soil model and binary wetland parameterization, as discussed earlier. Farther south, CLM4Me, SDGVM, and the GIEMS dataset have a peak in wetland extent around $20^{\circ}-30^{\circ} \mathrm{N}$. This is a prominent rice agriculture band, and the rice growing regions have been masked out of other models, reducing the natural wetland extent in these areas (Table A1). Around the equator, the use of the GIEMS inundation dataset by models is espe- cially apparent. Both SDGVM and UVic-ESCM show very large wetland extents around the equator larger than (UVicESCM), or similar in size (SDGVM) to, the high northern latitude peaks. The other models simulate a smaller equatorial wetland peak extent than the area above $45^{\circ} \mathrm{N}$.

Comparing the models' mean value (which excludes LPJBern's wet mineral soils) to the K07 and GIEMS datasets shows a general agreement in pattern, but the model mean (and percentile distribution) is higher in most latitudes. The 
general agreement in spatial pattern is expected considering that several of the models either use directly, or are parameterized to scale with, the GIEMS dataset. Monthly zonally averaged wetland area plots for 1993 to 2004 for each model are discussed in Appendix A1.

Several conclusions can be drawn from the simulated wetland extents. First, there is little agreement between the models for the magnitude of maximal wetland extent, with an almost four-fold difference across the suite of models (excluding here the wet mineral soils of LPJ-Bern). Estimates from inundation and wetland mapping datasets constrain the observed maximal wetland extent to the lower range of the model estimates, but those observational datasets have several discrepancies that make their use problematic. Additionally, there is little agreement between the published wetland extent estimates, with an almost three-fold difference between them (Table 2). Second, the models have best agreement zonally in the high northern latitudes above $45^{\circ} \mathrm{N}$. The greatest differences are in the equatorial band, with models that use the inundation dataset simulating a much smaller peak in wetlands than those that find wetland extents independently. Third, the seasonal dynamics of wetland extent also do not show a strongly consistent pattern between the models. A general pattern of higher wetland extent in the boreal summer is supported by most models, however the months, and magnitude, of peak wetland extent are not consistent. The models also fail to produce a trend in wetland area across 1993 to 2004 as is reported for global inundation (Papa et al., 2010). Lastly, our present uncertainties in modelling global wetland dynamics will only magnify uncertainties in the methane emissions simulated from those wetlands.

\subsection{Simulated methane emissions}

\subsubsection{Annual $\mathrm{CH}_{4}$ emissions}

Annual global methane emitted to the atmosphere for the period 1993-2004 is estimated by the models to be between about 140 and $260 \mathrm{TgCH}_{4} \mathrm{yr}^{-1}$ with a mean value of $\sim 190 \mathrm{TgCH}_{4} \mathrm{yr}^{-1}$ (Table 3). The basic parameterization of each model's $\mathrm{CH}_{4}$ scheme is listed in Table 1, with greater detail provided in Wania et al. (2012). The WETCHIMP model estimates generally fall within the range of inverse model estimates and are bracketed by some of the early forward-model results. The WETCHIMP models estimate a slightly higher fraction of $\mathrm{CH}_{4}$ emissions to come from the tropics $(66 \%)$ and less from the extratropics $(27 \%)$ than the recent inverse modelling results of Bloom et al. (2010) (55\% and $42 \%$, respectively) and are similar to Bousquet et al. $(2006,2011)(\sim 63 \%$ and $\sim 30 \%$, respectively). While this seems reassuring that different model techniques (forward and inverse) yield reasonably close estimates, the convergence of these estimates provides no proof of their accuracy. Indeed, neither modelling approaches are independent of assumptions (priors for the inverse models and tuning for the forward models), so similar results are expected.

To compare the simulated $\mathrm{CH}_{4}$ emissions to observationally based estimates, we require datasets that are of similar temporal and spatial scale. The temporal scale of the emissions presented here are monthly to annual, thus we require observational datasets to span similar periods of time. The spatial scale of the observational datasets is especially important as the smallest grid size presented here is $0.5^{\circ} \times 0.5^{\circ}$. Many observational studies of $\mathrm{CH}_{4}$ emissions are for point locations (e.g. Moore and Roulet, 1990; Chasar et al., 2000) or take an approach of upscaling from sparse measurements (e.g. Smith et al., 2000; Melack et al., 2004). Upscaling of point measurements introduces large uncertainties due to the influence of spatial heterogeneity, as well as uncertainties around accurately capturing emissions from ebullition, diffusion, and plant-mediated transport (van Bodegom et al., 2002). Ideally, to ensure a consistent spatial reference, we require measurements conducted over broad areas such as airmass back trajectory analysis, aircraft or large flux tower datasets, or concurrent chamber observations across relevant spatially heterogenous terrain features. Specifically, the areas should be large enough to encompass several grid cells to reduce the influence of inaccuracies in the model inputs (such as soil texture, climate, vegetation, and topography). With these constraints, we are not aware of any studies conducted in the tropics that would allow comparison with our model results, although it does appear that some promising projects are currently underway (Guerrero et al., 2011). This lack of comparative datasets is a major deficiency in our ability to evaluate the models' performance in the regions that contribute the largest share of global $\mathrm{CH}_{4}$ emissions (Denman et al., 2007) (Table 3).

The boreal region is better studied on large spatial scales. The HBL (Harriss et al., 1994; Roulet et al., 1994; Worthy et al., 2000; Pickett-Heaps et al., 2011) and West Siberian Lowlands (Winderlich et al., 2010; Glagolev et al., 2011), in particular, have several large-scale studies that estimate annual emissions. Focusing on the HBL (the West Siberian Lowlands will be discussed in a follow-up paper, Bohn et al., 2013 in preparation), the most recent analysis estimated annual emissions for the period 2004-2008 using ARC-TAS and pre-HIPPO aircraft campaigns in May-July 2008 and long-term monitoring from two sites located north (Alert, Northwest Territories) and south (Fraserdale, Ontario) of the HBL. These observations were interpreted with wetland bottom-up modelling integrated into a global chemical transport model (GEOS-CHEM). From this approach, the mean $\mathrm{CH}_{4}$ emissions were estimated to be $2.3 \pm 0.3 \mathrm{Tg} \mathrm{yr}^{-1}$ (Pickett-Heaps et al., 2011). This estimate is larger than a previous estimate of $0.5 \pm 0.3 \mathrm{TgCH}_{4} \mathrm{yr}^{-1}$ from the ABLE3B/NOWES surface and aircraft field study from July 1990 (Harriss et al., 1994; Roulet et al., 1994). The differences in these estimates demonstrates some of the challenges of up-scaling measurements to large regions, as was done in 


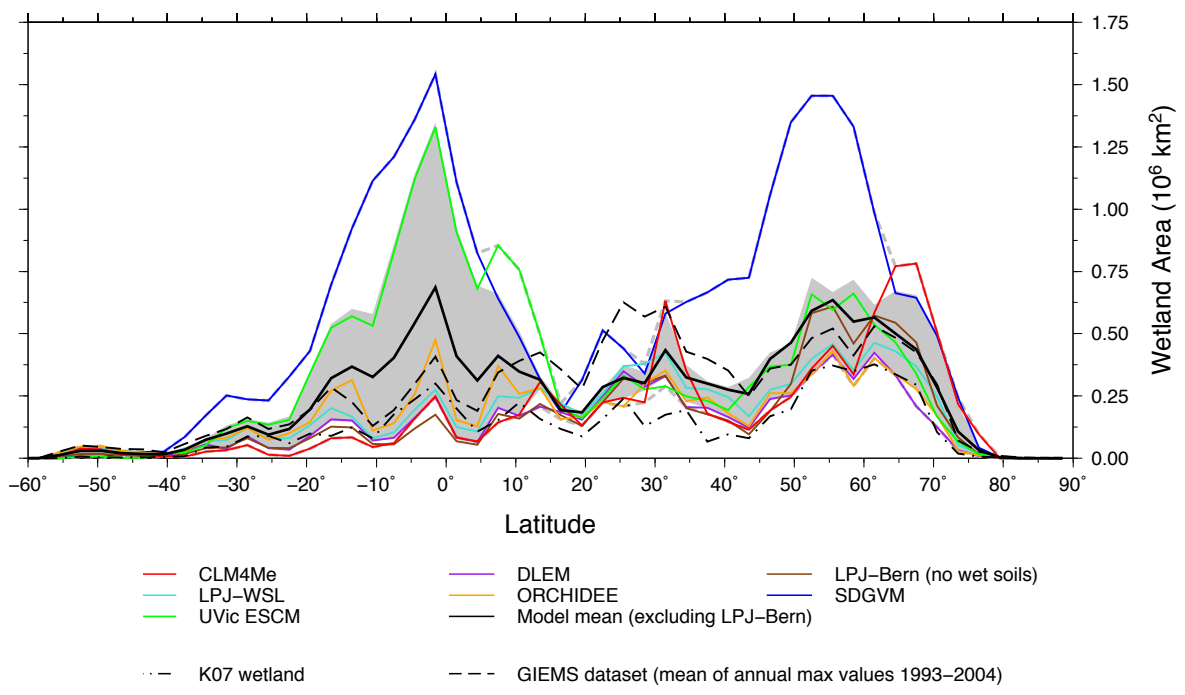

Fig. 3. Zonal sum of mean annual maximal wetland area for 1993-2004 for all models that have dynamic wetland extents. LPJ-Bern is plotted here excluding its wet mineral soils (keeping inundated areas and peatlands). Also included are the K07 and GIEMS datasets. The grey shading denotes the 25th and 75th percentiles of the model distribution (excluding LPJ-Bern); the grey dashed lines the 5th and 95th. The wetland extents are summed across $3^{\circ}$ bins.

the ABLE-3B/NOWES studies (Harriss et al., 1994; Roulet et al., 1994), with much of the difference due to spatial heterogeneity across the HBL region. From the same two sites used by Pickett-Heaps et al. (2011), an earlier study by Worthy et al. (2000) used inverse methods to estimate an annual $\mathrm{CH}_{4}$ flux of $0.2-0.5 \mathrm{Tg} \mathrm{yr}^{-1}$ for the HBL.

Table 3 lists the simulated mean $\mathrm{CH}_{4}$ emissions over the period 1993-2004. The wetland models on average estimate $\mathrm{CH}_{4}$ emissions for the HBL a little over double that of Pickett-Heaps et al. (2011) and an order of magnitude greater than the estimates of Harriss et al. (1994), Roulet et al. (1994), and Worthy et al. (2000).

It is surprising for SDGVM to have a relatively low HBL $\mathrm{CH}_{4}$ flux estimate but be on the high end of global $\mathrm{CH}_{4}$ estimates. For the HBL, the soil texture information used by SDGVM could be part of the reason, as only part of the region is found to be wetlands by the SDGVM dynamic wetlands scheme. The largest $\mathrm{CH}_{4}$ flux is simulated by LPJBern. This value is related to peaks in $\mathrm{CH}_{4}$ emission for the 1998, 1999, and 2001 simulation years and is a model artefact (full description in Wania et al., 2012). Outside of these years, LPJ-Bern simulates a mean $\mathrm{HBL} \mathrm{CH}_{4}$ flux of $7.2 \pm 1.7 \mathrm{Tg} \mathrm{yr}^{-1}$. An additional reason the models could be high compared to these other estimates is the influence of 1998 on the mean of 1993-2004, which was a year of of exceptional warmth and moisture in the boreal region that has been suggested to have greatly increased boreal $\mathrm{CH}_{4}$ emissions (see discussion in Sect. 3.2.3).

\subsubsection{Methane emissions spatial distribution}

The mean spatial distribution of $\mathrm{CH}_{4}$ emissions with meridional and zonal sums for 1993-2004 are shown in Fig. 4. The spatial pattern of $\mathrm{CH}_{4}$ emissions per model is obviously dependent upon the presence or absence of wetlands, yet the intensity of emissions reflects internal model dynamics.

The models, taken as a whole, simulate the strongest methane fluxes in the tropical regions with a general, nonuniform decline into higher latitudes. The meridional sums of the models have a common pattern of a large peak corresponding to the longitudes of the Amazon. The models also generally simulate a small peak at longitudes corresponding to the Congo region of Africa and a moderate peak for Southeast Asia. These patterns show large variability amongst the models, with a general tendency for models with smaller wetland areas simulating higher methane fluxes. Further discussion on the differences between models can be found in Appendix A2.

Plotting the zonal sums of the models together shows reasonable agreement between the models (Fig. 5). The models generally simulate a large peak of $\mathrm{CH}_{4}$ emission in the tropics (as is also evident in Table 3 ) and smaller secondary peaks centred on $25^{\circ} \mathrm{N}$ and $55^{\circ} \mathrm{N}$. The peak around $25^{\circ} \mathrm{N}$ is likely slightly overestimated due to some models not masking rice agriculture that is present in that region (Leff et al., 2004) (Table A1). ORCHIDEE stands out with prominent peaks in the Southern Hemisphere that are also simulated by IAPRAS, as well as a lower latitude boreal peak around $45^{\circ} \mathrm{N}$. IAP-RAS's boreal $\mathrm{CH}_{4}$ emissions are well within the models' 25th to 75th percentile distribution, but outside of this region IAP-RAS is commonly an outlier. This relates to the 

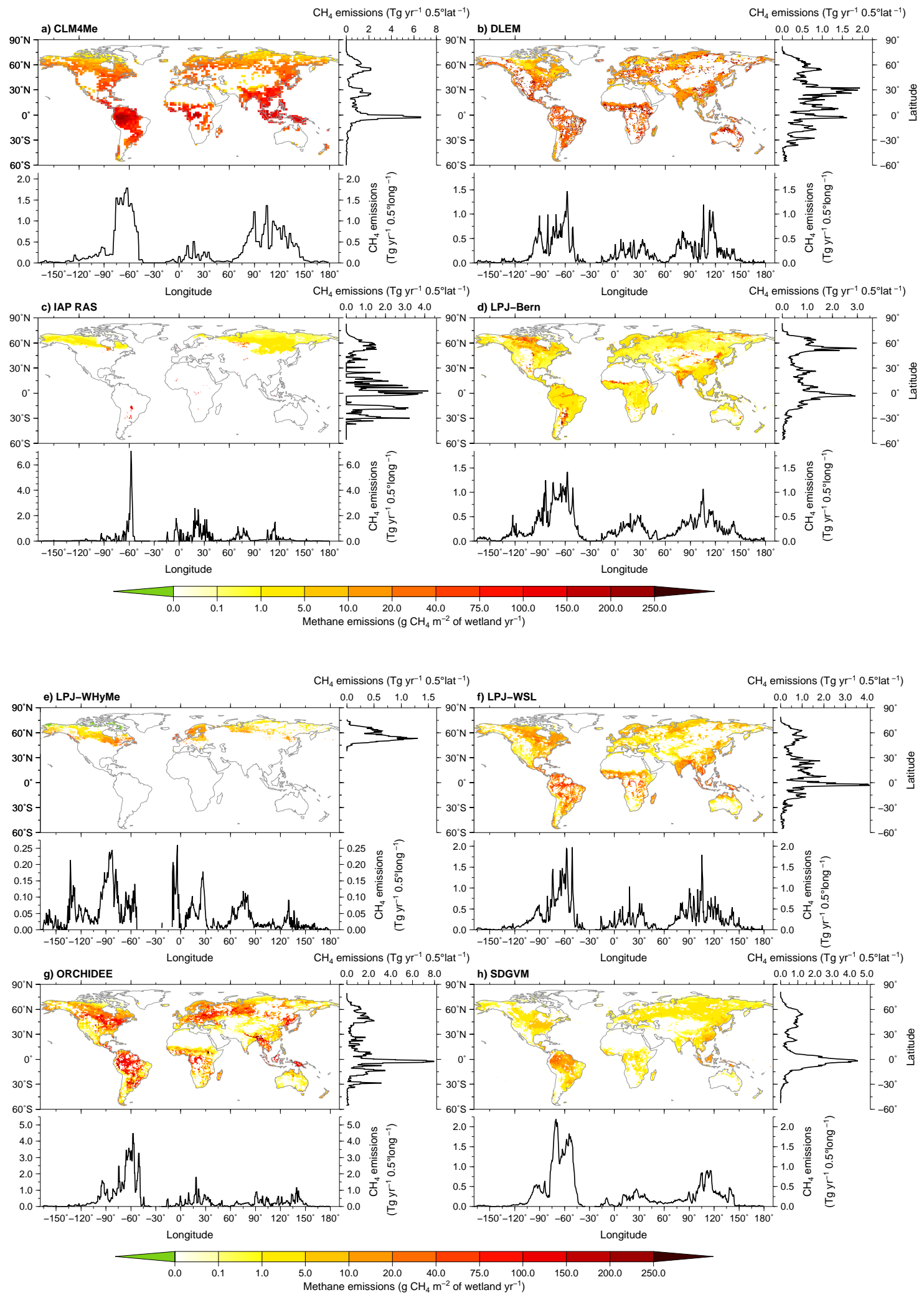

Fig. 4. Global maps of mean annual $\mathrm{CH}_{4}$ flux intensity per meter squared of wetland with meridional and zonal emission sums for 1993 to 2004. The zonal and meridional sums are per $0.5^{\circ}$ of latitude/longitude. The CLM4Me and ORCHIDEE models were interpolated to a $0.5^{\circ}$ grid to allow inter-comparison with the other models. 
Table 3. Simulated annual mean total methane emitted to atmosphere from natural wetlands for $1993-2004$. All units are $\mathrm{Tg} \mathrm{CH}_{4} \mathrm{yr}^{-1} \pm 1 \sigma$, where the standard deviation represents the inter-annual variation in the model estimates. Note that estimates from some other reference studies are not for the same time period, or are for slightly different geographic regions. These exceptions are noted in the table footnotes.

\begin{tabular}{|c|c|c|c|c|}
\hline Model & Global & Tropics $\left(30^{\circ} \mathrm{S}-30^{\circ} \mathrm{N}\right)$ & Extratropics $\left(>35^{\circ} \mathrm{N}\right)^{\mathrm{a}}$ & $\mathrm{HBL}^{\mathrm{b}}$ \\
\hline LPJ-Bern ${ }^{c}$ & $181 \pm 15$ & $106 \pm 2$ & $65 \pm 13$ & $11.3 \pm 7.9$ \\
\hline CLM4Me & $206 \pm 6$ & $134 \pm 5$ & $62 \pm 6$ & $3.4 \pm 0.3$ \\
\hline DLEM & $141 \pm 11$ & $85 \pm 7$ & $39 \pm 3$ & $2.9 \pm 0.2$ \\
\hline IAP-RAS & $164 \pm 4$ & $115 \pm 2$ & $43 \pm 2$ & $4.7 \pm 1.1$ \\
\hline LPJ-WHyMe & & & $27 \pm 2$ & $5.5 \pm 1.0$ \\
\hline LPJ-WSL & $174 \pm 10$ & $122 \pm 7$ & $42 \pm 2$ & $3.9 \pm 0.3$ \\
\hline ORCHIDEE & $264 \pm 12$ & $184 \pm 11$ & $71 \pm 4$ & $9.1 \pm 1.7$ \\
\hline SDGVM & $199 \pm 5$ & $135 \pm 6$ & $59 \pm 3$ & $2.2 \pm 0.2$ \\
\hline Mean $\pm 1 \sigma$ & $190 \pm 39$ & $126 \pm 31$ & $51 \pm 15$ & $5.4 \pm 3.2$ \\
\hline \multicolumn{5}{|l|}{ Forward model estimates: } \\
\hline Fung et al. (1991) & & & $35^{\mathrm{d}}$ & \\
\hline Cao et al. (1996) & 92 & 55 & 30 & \\
\hline Walter et al. $(2001)^{\mathrm{e}}$ & 260 & & $\sim 65$ & \\
\hline \multicolumn{5}{|l|}{ Inverse model estimates: } \\
\hline Hein et al. (1997) & $231 \pm 27$ & & & \\
\hline Worthy et al. (2000) & & & & $0.2-0.5$ \\
\hline Houweling et al. $(2000)^{\mathrm{f}}$ & $163 \pm 16$ & & & \\
\hline Wang et al. (2004) $\mathrm{g}$ & $176 \pm 10$ & & & \\
\hline Mikaloff Fletcher et al. $(2004)^{\mathrm{h}}$ & $231 \pm 46$ & & & \\
\hline Chen and Prinn $(2006)^{\mathrm{i}}$ & $145 \pm 28$ & & & \\
\hline $\begin{array}{l}\text { Reference scenario Bousquet et al. (2006) } \\
\text { and Bousquet et al. (2011) }\end{array}$ & $145 \pm 10$ & $91 \pm 11$ & $43 \pm 4$ & \\
\hline $\begin{array}{l}\text { Mean of alternate scenarios } \\
\text { in Bousquet et al. }(2011)^{\mathrm{j}}\end{array}$ & $151 \pm 10$ & $97 \pm 10$ & $43 \pm 4$ & \\
\hline Bloom et al. $(2010)^{\mathrm{k}}$ & $165 \pm 50$ & $91 \pm 28$ & $69 \pm 20$ & $4.9 \pm 1.4^{1}$ \\
\hline \multicolumn{5}{|l|}{ Observation-based estimates: } \\
\hline Pickett-Heaps et al. (2011) & & & & $2.3 \pm 0.3$ \\
\hline \multicolumn{5}{|c|}{$\begin{array}{l}\text { a Northern extratropical region low latitude limit chosen to coincide with the low latitude limit of the peatland distribution in Tarnocai et al. (2009) used by the } \\
\text { LPJ-WHyMe model. }\end{array}$} \\
\hline \multicolumn{5}{|c|}{$\begin{array}{l}\text { b Hudson Bay lowland region is included to allow direct comparison to independent estimates from Pickett-Heaps et al. (2011) and encompasses } 50^{\circ} \mathrm{N}-60^{\circ} \mathrm{N} \\
\text { and } 75^{\circ} \mathrm{W}-96^{\circ} \mathrm{W} \text {. } \\
{ }^{c} \text { Excluding } \mathrm{NH}_{4} \text { emissions from wet mineral soils for LPJ-Bern gives lower estimates of global }(93 \pm 14) \text {, tropical }(41 \pm 1) \text {, extratropical }(48 \pm 13) \text { and } \mathrm{HBL} \\
(11.1 \pm 7.9) \mathrm{CH}_{4} \text { emissions. } \\
{ }^{\mathrm{d}} \text { Wetlands and tundra } \mathrm{CH}_{4} \text { emissions }>50^{\circ} \mathrm{N} \text {. } \\
\mathrm{e}^{\mathrm{e}} \text { For the period } 1982-1993 \text { and extratropical wetlands are considered }>30^{\circ} \mathrm{N} \text {. }\end{array}$} \\
\hline \multicolumn{5}{|l|}{ f Value is for the pre-industrial period (pre-1850). } \\
\hline \multicolumn{5}{|l|}{$\begin{array}{l}\text { Value is for the period } 1988-1997 . \\
\text { h Swamps, bogs, and tundra for } 1998-2000 .\end{array}$} \\
\hline \multicolumn{5}{|l|}{ i This estimate implicitly includes rice emissions. } \\
\hline \multicolumn{5}{|c|}{ j Values are a 2012 update for the reference scenario (P. Bousquet, personal communication, 2012). } \\
\hline \multicolumn{5}{|c|}{$\begin{array}{l}\mathrm{k} \text { Estimate is an average of years } 2003 \text { and 2004. Mean values for the five year period, 2003-2007, are } 171 \pm 52 \text { (global), } 92 \pm 28 \text { (tropics), } 74 \pm 22 \\
\text { (extratropics), and } 5.1 \pm 1.5 \text { (HBL). }\end{array}$} \\
\hline
\end{tabular}

sparse wetlands, outside of the boreal region, that are prescribed for IAP-RAS. DLEM is also commonly outside of the models' 25 th to 75 th percentile distribution, particularly close to the equator.
The relative latitudinal contributions and seasonal timing of $\mathrm{CH}_{4}$ fluxes varies greatly between the models (see Fig. 6 with further discussion in Appendix A1). There is, however a consistent pattern of peak global $\mathrm{CH}_{4}$ emissions in boreal summer across all models. The principal contributing latitudinal band of that increase is $40^{\circ}-90^{\circ} \mathrm{N}$. 


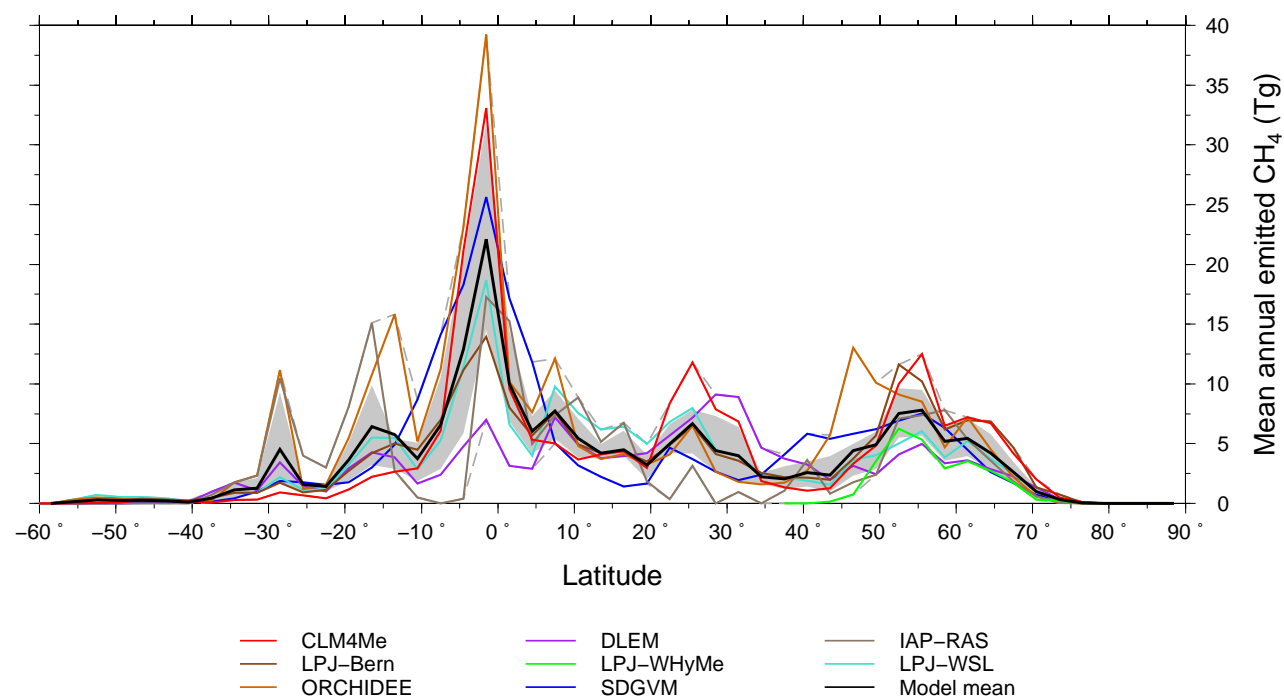

Fig. 5. Zonally summed mean annual $\mathrm{CH}_{4}$ emissions for 1993-2004. The grey shading denotes the limits of the 25th and 75th percentile of the model distribution. Grey dashed lines are the 5th and 95th percentile limits. The $\mathrm{CH}_{4}$ emissions are summed across $3^{\circ}$ bins.

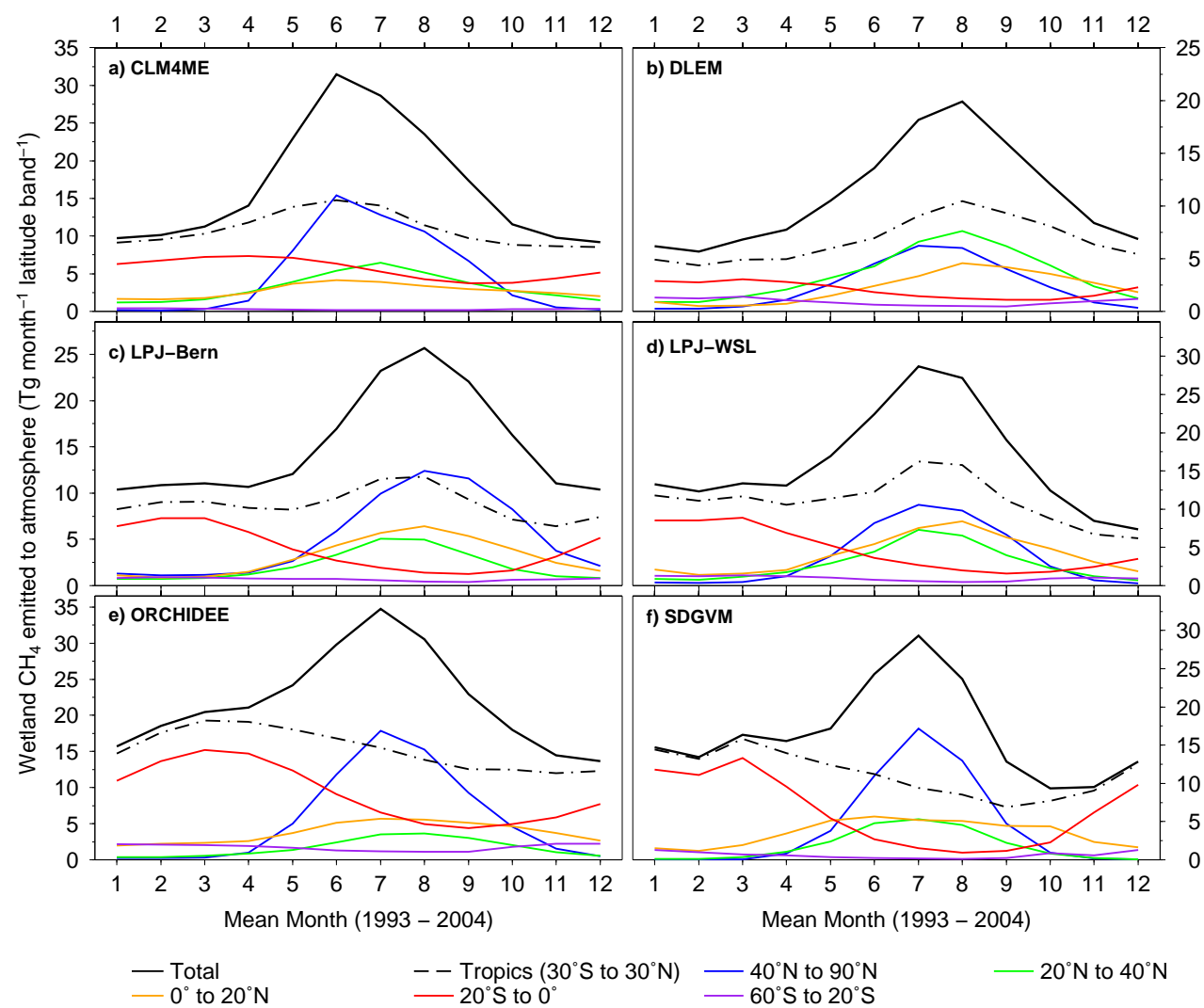

Fig. 6. Mean monthly simulated methane emissions by latitudinal band for 1993-2004 for all models with monthly emissions and global extent. Note the magnitude of the y-axes differs between models. 
Table 4. Spearman correlation coefficients $(\rho)$ for monthly wetland area and $\mathrm{CH}_{4}$ emissions over the period 1993-2004 (see Figure 7). The model mean excludes LPJ-Bern due to its wet mineral soils parameterization.

\begin{tabular}{|c|c|c|c|}
\hline Model & Global & $\begin{array}{l}\text { Tropics } \\
\left(30^{\circ} \mathrm{S}-30^{\circ} \mathrm{N}\right)\end{array}$ & $\begin{array}{l}\text { Extratropics } \\
\left(>35^{\circ} \mathrm{N}\right)^{\mathrm{a}}\end{array}$ \\
\hline LPJ-Bern ${ }^{b}$ & 0.067 & 0.511 & 0.267 \\
\hline CLM4Me & 0.931 & 0.247 & 0.980 \\
\hline DLEM & 0.885 & 0.877 & 0.848 \\
\hline LPJ-WSL & 0.910 & 0.798 & 0.990 \\
\hline ORCHIDEE & 0.920 & 0.508 & 0.944 \\
\hline SDGVM & 0.845 & 0.910 & 0.979 \\
\hline $\begin{array}{l}\text { Model Mean } \\
\text { (excl. LPJ-Bern) }\end{array}$ & 0.898 & 0.668 & 0.948 \\
\hline
\end{tabular}

a Northern extratropical region low latitude limit chosen to coincide with the low latitude limit of the peatland distribution in Tarnocai et al. (2009) used by the LPJ-WHyMe model.

$\mathrm{b}$ Excluding the wet mineral soils of LPJ-Bern results in $\rho$ values of 0.843 (global), 0.908 (tropics), and 0.940 (extratropics).

\subsubsection{Simulated wetland areal extent and $\mathrm{CH}_{4}$ emissions for the 1993-2004 period}

Normalizing the monthly global wetland areal extent and $\mathrm{CH}_{4}$ fluxes facilitates a comparison between model responses to inter-annual and intra-annual changes in climate (left-hand column of Fig. 7). To normalize each model, all values were divided by the maximum value for that model over the period 1993-2004, giving a fractional value between 0 and 1 . The models have some striking differences in both the magnitude and timing of $\mathrm{CH}_{4}$ emissions relative to wetland area. CLM4Me has a strong early peak in $\mathrm{CH}_{4}$ emissions that declines in magnitude before the decline of the wetland extent in most years (Fig. 7a). This early boreal summer peak in $\mathrm{CH}_{4}$ flux, that drops before wetland extent, is also a prominent feature of LPJ-Bern (Fig. 7c), however LPJBern also has a strong secondary peak in wetland/wet soils extent that only slightly increases $\mathrm{CH}_{4}$ emissions. This secondary peak is driven by the low $\mathrm{CH}_{4}$ producing wet mineral soils parameterization (Fig. 2c).

CLM4Me also has a similar relative change in emissions and wetland extent over the course of a year, indicating that wetland area explains a large amount of the model's $\mathrm{CH}_{4}$ variations. Indeed, the global Spearman correlation coefficient $(\rho)$, calculated between global monthly wetland extent and $\mathrm{CH}_{4}$ emissions, for CLM4Me is 0.931 with the extratropics even higher (0.980), and the tropics weaker $(0.247)$ (Table 4). Conversely, DLEM simulates much larger relative changes in $\mathrm{CH}_{4}$ fluxes than wetland extent, indicating other factors strongly influence $\mathrm{CH}_{4}$ emissions in their model (Fig. 7b). DLEM also commonly has its methane emissions peak at the peak of wetland extent, not biased towards the early part of the wetland extent peak as in CLM4Me or LPJBern. The correlation between wetland extent and $\mathrm{CH}_{4}$ emis- sions for DLEM is similar to the model mean with a similar value between the tropics and extratropics. LPJ-Bern has the smallest relative changes in wetland/wet soils area of $\sim 30 \%$, again due to the wet mineral soils parameterization, but the relative changes in $\mathrm{CH}_{4}$ emissions are still relatively large at $\sim 40 \%$. LPJ-Bern has no correlation between global wetland area and $\mathrm{CH}_{4}$ emissions (0.067), but removing consideration of wet mineral soils raises the global $\rho$ value to 0.843 , well in line with the other models. LPJ-WSL simulates a consistent pattern of similar magnitude relative changes in wetland extent and $\mathrm{CH}_{4}$ emissions (Fig. 7d). A slightly larger drop in $\mathrm{CH}_{4}$ emissions relative to wetland extent is simulated during the boreal winter for most years. The ORCHIDEE relationship between wetland area and $\mathrm{CH}_{4}$ emissions is slightly above average $(0.920)$ with a global value similar to the all-model mean (0.898), though with less correlation in the tropics $(0.508)$ than the mean of the models (0.668). SDGVM also has close links between the timing and magnitude of wetland extent and $\mathrm{CH}_{4}$ emissions (Fig. 7f) similar to CLM4Me and LPJ-WSL.

The relative changes in wetland area and $\mathrm{CH}_{4}$ emissions inter-annually show good similarity between the models (righthand side of Fig. 7). All models simulate 1998 to be a year of high $\mathrm{CH}_{4}$ emissions over the 1993-2004 period. DLEM and LPJ-WSL simulate total $\mathrm{CH}_{4}$ emissions for 1998 to be less than 1993 and 1994; both years have higher wetland extent in the GIEMS dataset. ORCHIDEE simulates slightly less $\mathrm{CH}_{4}$ emissions in 1998 than 2000. LPJ-Bern has a very prominent 1998 peak in $\mathrm{CH}_{4}$ emissions. This peak corresponds to a large release of $\mathrm{CH}_{4}$ in the boreal regions as has been discussed earlier and is likely an overestimate (see Wania et al., 2012, for full discussion). All models show smaller $\mathrm{CH}_{4}$ emissions in 1997 than 1998. This period is of interest as it covers the largest magnitude El Niño on record. Dlugokencky et al. (2001) report a significant increase in the global atmospheric $\left[\mathrm{CH}_{4}\right]$ growth rate corresponding to an additional $24 \mathrm{TgCH}_{4} \mathrm{yr}^{-1}$ imbalance in the sources and sinks of $\mathrm{CH}_{4}$ for 1998 compared to the previous three years. They used a version of the Walter (1998) model to estimate a global wetland $\mathrm{CH}_{4}$ flux increase of $7.3 \%$ for 1998 over 1997. The WETCHIMP models, on average, estimate a $6 \%$ increase in global $\mathrm{CH}_{4}$ emissions for 1998 over 1997 (excluding LPJ-Bern this increase drops to $4.5 \%$ ). Chen and Prinn (2006) used an inverse model to estimate a slightly higher wetland $\mathrm{CH}_{4}$ flux increase $(\sim 10 \%)$ between the same two years. An increase in wetland $\mathrm{CH}_{4}$ emissions for 1998 was also found by Mikaloff Fletcher et al. (2004) using a ${ }^{13} \mathrm{CH}_{4} /{ }^{12} \mathrm{CH}_{4}$ and $\left[\mathrm{CH}_{4}\right]$-informed inverse model for 1998-1999. They estimated the wetland contribution for 1998 was $40 \mathrm{TgCH}_{4} \mathrm{yr}^{-1}$ (or $\sim 20 \%$ ) larger than 1999. The WETCHIMP models estimate a more modest mean difference of $4.1 \%\left(\sim 5 \mathrm{Tgyr}^{-1}, 3 \%\right.$ excluding LPJBern) for 1998 over 1999, suggesting the Mikaloff Fletcher et al. (2004) value is an overestimate. Not all studies find large changes. For example, Bousquet et al. (2006) used an 

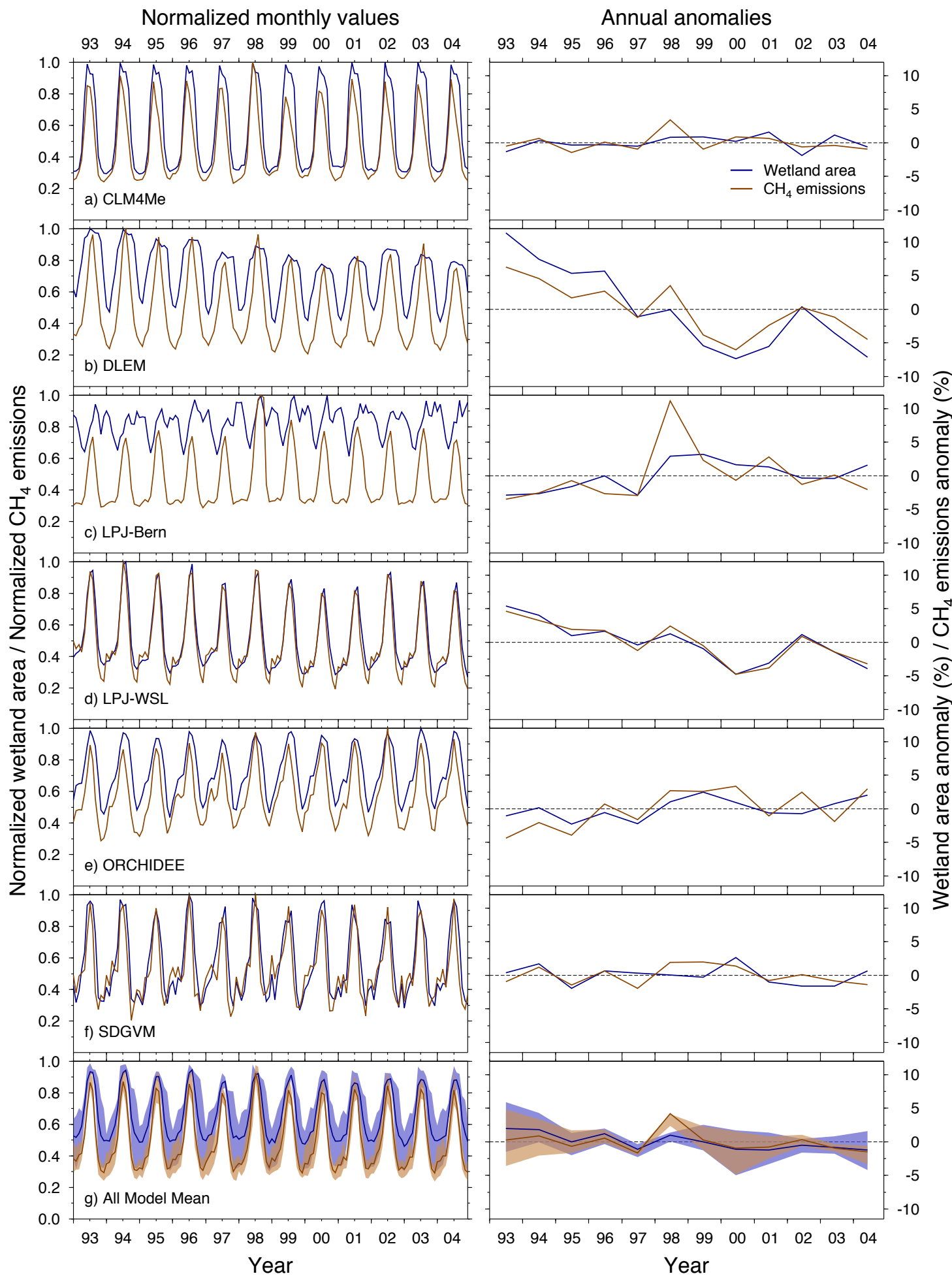

Fig. 7. Global normalized monthly wetland area and $\mathrm{CH}_{4}$ emissions (left column) and global annual $\mathrm{CH}_{4}$ emissions and wetland area percent anomalies (right column) for 1993-2004. The Spearman correlation coefficients are listed in Table 4. Anomalies are calculated relative to the maximal value of 1993-2004 for each model, where the maximal value is set to 1 and the other values scale between 0 and 1 . The model mean value includes all models. Shading indicates the models' 25 th and 75 th percentile distributions. 
inverse model to estimate generally stable natural wetland $\mathrm{CH}_{4}$ emissions over the 1997-1998 period, with a drop in northern wetland $\mathrm{CH}_{4}$ emissions in 1997 and an increase in southern emissions in 1998. Bousquet et al. (2006) also show a consistent trend of declining wetland emissions after 1998, coinciding with the smaller inundated area globally as observed by Papa et al. (2010). There is not a consistent pattern of maximal wetland extent corresponding with the peak in $\mathrm{CH}_{4}$ emissions in 1998, however all models do show 1997 to have below average wetland extent for the period. The WETCHIMP models also do not show a trend in wetland area over the 1993-2004 period (the two models with a strong trend, LPJ-WSL and DLEM, have their annual maximal wetland extent set to the GIEMS dataset).

Importantly, the models do not appear to respond solely to warmer temperatures, as 2002 and 2003 were essentially as warm as 1998 (Hansen et al., 2010), but the models do not show elevated $\mathrm{CH}_{4}$ fluxes as in 1998. The main difference between 2002/2003 and 1998 are that 1998 was a very strong El Niño year while 2002 and 2003 had much milder El Niño conditions. Global precipitation for 1998 was high, particularly in the northern extratropics with record levels in those regions (latitude bands spanning $85^{\circ} \mathrm{N}-55^{\circ} \mathrm{N}$ and $55^{\circ} \mathrm{N}-30^{\circ} \mathrm{N}$ ), while 2002 and 2003 were both below the 1961-1990 global average (NOAA National Climatic Data Center, 2003).

We can conclude four main points about the WETCHIMP models' simulated methane emissions. First, the models' simulated global total $\mathrm{CH}_{4}$ emissions are in-line with previous estimates from both forward and inverse models, a result that is expected given the assumptions inherent to both techniques. However, given the large range between the models ( $\pm 40 \%$ of the models' mean), forward models, at present, appear unable to further narrow the uncertainty of global wetland $\mathrm{CH}_{4}$ emissions. Regionally, we lack appropriate observational datasets to evaluate the models. For one well-studied area, the HBL, many models appear to overestimate emissions, sometimes several-fold over previous estimates. Second, the models have similar disagreement in the relative timing of emissions throughout the year as they do for periods of maximum wetland extent. Given that the models' mean global correlation $\rho$ value between $\mathrm{CH}_{4}$ emissions and wetland extent is 0.898 , it is evident that errors in the timing and spatial extent of wetlands will strongly impact predicted $\mathrm{CH}_{4}$ emissions, as has been shown before (Petrescu et al., 2008). Third, model agreement for zonal methane emissions has better internal agreement between the models than the simulated wetland extent, with most models showing a large tropical and smaller boreal $\mathrm{CH}_{4}$ emissions peak. Lastly, the models estimate a mean increase in global wetland $\mathrm{CH}_{4}$ for 1998 over 1997 of about $4.5 \%$, on the low-end of inverse and observationally based estimates. This increase corresponds to one of the strongest El Niños on record demonstrating the models' sensitivity to transient warm and wet events.

\subsection{Sensitivity tests}

\subsubsection{Sensitivity of $\mathrm{CH}_{4}$ emissions and wetland area to increased atmospheric $\mathrm{CO}_{2}$ concentrations}

The change in simulated wetland extent and $\mathrm{CH}_{4}$ emissions from equilibrium due to increasing $\left[\mathrm{CO}_{2}\right]$ (step increase from $\sim 300$ to $857 \mathrm{ppm}$ ) is shown in Fig. 8 and annual percent change in Table 5. All models estimate a significant increase in global, tropical, and extratropical $\mathrm{CH}_{4}$ emissions and global wetland extent under elevated $\left[\mathrm{CO}_{2}\right]$. While, globally, the net change is an increase in $\mathrm{CH}_{4}$ flux and wetland area, spatially, some models show areas of decreasing wetland extent, especially ORCHIDEE, but also SDGVM and CLM4Me. The model with the largest sensitivity to increased $\left[\mathrm{CO}_{2}\right]$ is ORCHIDEE, with a $\sim 160 \%$ increase in global $\mathrm{CH}_{4}$ flux. Excluding ORCHIDEE, the mean globally integrated increase drops from $73.2 \pm 49.1 \%$ to $55.4 \pm 25.5 \%$. ORCHIDEE, while having the strongest response in $\mathrm{CH}_{4}$ emissions, simulates only the third largest increase in wetland area. This reflects the more mixed pattern of increase and decrease in wetland extent for ORCHIDEE (Fig. 8d).

The increase in global wetland areal extent was highest for UVic-ESCM at $\sim 13 \%$. Increases in UVic-ESCM wetland area, and indeed the rest of the models as well, are likely due to reduced evapotranspiration (ET). Elevated $\left[\mathrm{CO}_{2}\right]$ allows plants to increase stomatal closure, reducing water loss by the plant. The decreased water loss reduces water demand from the soil, increasing soil moisture and thus increasing wetland extent. For UVic-ESCM, the model ET parameterization is strongly sensitive to $\mathrm{CO}_{2}$, and the wetland determination scheme is directly derived from soil moisture, so the model responds strongly to increasing $\left[\mathrm{CO}_{2}\right]$. While the wetland determination of UVic-ESCM is directly related to soil moisture, the mechanism of wetland areal extent expansion due to reduced ET is common to the models.

The general increase in $\mathrm{CH}_{4}$ emissions under elevated $\left[\mathrm{CO}_{2}\right]$ is also due to $\mathrm{CO}_{2}$ fertilization promotion of higher NPP. Large increases in modelled NPP under increased $\left[\mathrm{CO}_{2}\right]$ is commonly reported, including a study of eleven coupled climate-carbon models as part of $\mathrm{C}^{4} \mathrm{MIP}$ (Friedlingstein et al., 2006). Observations have shown that with higher NPP, more plant photosynthates are allocated to the rhizosphere where the root exudates provide increased carbon for soil microbial communities' reduction to $\mathrm{CH}_{4}$ (Chanton et al., 1995; Vann and Megonigal, 2003; Whiting and Chanton, 1993). Few models explicitly simulate exudates (Wania et al., 2012), so in the majority of models, the linkage between the $\mathrm{CO}_{2}$ enrichment and enhanced $\mathrm{CH}_{4}$ emissions comes from prescribing $\mathrm{CH}_{4}$ emissions as a direct fraction of NPP, or prescribing emissions as a fraction of heterotrophic respiration $\left(R_{\mathrm{h}}\right)$, which is related to NPP (Table $1)$. This difference between the model approaches could be important, as there is presently no consensus on changes in 
the ratio between NPP and $R_{\mathrm{h}}$ under future climate changes (Friedlingstein et al., 2006).

Most models show a stronger enhancement in $\mathrm{CH}_{4}$ emissions under elevated $\left[\mathrm{CO}_{2}\right]$ for the tropics over the extratropics. The stronger response from the tropics is primarily due to a greater change in NPP for the region over the extratropics. NPP enhancement is a strong lever on $\mathrm{CH}_{4}$ emissions, as ORCHIDEE's strong NPP enhancement under elevated $\left[\mathrm{CO}_{2}\right]$ partially explains its strong increase in global wetland $\mathrm{CH}_{4}$ emissions. This pattern in NPP response has been reported previously (for the LPJ model) (Hickler et al., 2008; Poulter et al., 2010). CLM4Me has the opposite pattern with a three-times stronger response from the extratropics. This model response comes from a combination of factors: (1) a stronger NPP enhancement in the extratropics than the tropics, (2) a strong increase in the ratio of emitted to produced $\mathrm{CH}_{4}$ in the extratropics, and (3) an increase in soil temperature of up to $2.5^{\circ} \mathrm{C}$ in the extratropics with a decrease in the tropics. The increase and decrease in soil temperature in the extratropics and tropics, respectively, occurred because of the impacts of $\left[\mathrm{CO}_{2}\right]$ on stomatal conductance, leading to a changed surface energy balance, soil evaporation, and transpiration. These complexities are discussed in more detail in Subin et al. (2012).

The general increase in methane emissions from $\mathrm{CO}_{2}$ enrichment, as simulated by the models, is supported by empirical evidence. Wetland ecosystems and mesocosms exposed to elevated atmospheric $\left[\mathrm{CO}_{2}\right]$ have generally shown an increase in $\mathrm{CH}_{4}$ fluxes across many studies (Hutchin et al., 1995; Megonigal and Schlesinger, 1997; Saarnio and Silvola, 1999; Saarnio et al., 2003), with some notable exceptions of no significant change (Kang et al., 2001), or even a decline in emissions (Silvola et al., 2003). There is also recent evidence that different wetland types, such as bogs vs. fens, respond differently to $\mathrm{CO}_{2}$ enrichment (Boardman et al., 2011), and other influences such as nitrogen $(\mathrm{N})$ deposition could counteract the effect of the $\mathrm{CO}_{2}$ enrichment (Saarnio and Silvola, 1999) or affect litter quality, decreasing $\mathrm{CH}_{4}$ fluxes (Pancotto et al., 2010). van Groenigen et al. (2011) performed a metaanalysis of studies investigating the effect of increased atmospheric $\left[\mathrm{CO}_{2}\right]$ to projected future increases in emissions of $\mathrm{CH}_{4}$ and $\mathrm{N}_{2} \mathrm{O}$ in soils. They anticipate an increase from natural wetlands of $13.2 \%$ (95\% bootstrapping confidence interval of $-4.8 \%$ to $35.7 \%, n=24)$ for an atmospheric $\left[\mathrm{CO}_{2}\right]$ of between $473-780 \mathrm{ppm}$. Our models' average is much higher than this, but we performed our tests with a higher $\left[\mathrm{CO}_{2}\right]$ $(857 \mathrm{ppm})$ than the upper bound of their range. Additionally, it is difficult to tell if the results are appropriate to compare due to differing rates of perturbation, and that our simulations were run until equilibrium was re-established.

While the models' results are generally consistent with the majority of empirical $\mathrm{CO}_{2}$ enrichment studies, the models are likely too simplistic in the limits they place on the conversion of substrate to $\mathrm{CH}_{4}$. No participating model distinguishes different wetland types, such as bogs vs. fens, ex- plicitly. This lack of distinction limits the models' ability to simulate divergent responses to $\mathrm{CO}_{2}$ enrichment, such as that observed by Boardman et al. (2011). Nutrient limitations to future increases in NPP are projected to be important (Hungate et al., 2003), but only a few of our models presently incorporate explicit accounting of the $\mathrm{N}$ cycle (SDGVM and CLM4Me). The lack of incorporation of nutrient cycles introduces uncertainty as studies explicitly accounting for $\mathrm{N}$ (Zaehle et al., 2010) and $\mathrm{N}$ and phosphorus (Goll et al., 2012) show a more muted NPP response to $\mathrm{CO}_{2}$ fertilization.

\subsubsection{Sensitivity of $\mathrm{CH}_{4}$ emissions and wetland area to increased air temperature}

Wetland area and $\mathrm{CH}_{4}$ flux anomalies due to increased surface air temperature (SAT) are presented in Fig. 9 and Table 5. Wetland area experiences a moderate decline in all models with a mean drop of $7.9 \pm 6.0 \%$ under elevated SAT. $\mathrm{CH}_{4}$ emissions have a general slight, non-significant, decline under warmer SAT $(-4.5 \pm 20.9 \%)$. IAP-RAS is the only model to simulate a large increase in $\mathrm{CH}_{4}$ emissions. This response is a result of the IAP-RAS prescribed soil hydrology and wetland extent that does not allow increased evaporation under warmer SAT and no change in wetland area. Methane production in IAP-RAS is then augmented by the increased SAT with an additional boost in the high latitudes due to shorter periods with snow cover, allowing summer warmth to penetrate deeper into the soil column. Excluding the result of IAP-RAS gives a small significant decrease in estimated global $\mathrm{CH}_{4}$ emissions of $-11.5 \pm 11.2 \%$.

The decrease in $\mathrm{CH}_{4}$ flux is not uniform across latitudes. On average, the tropics decrease in $\mathrm{CH}_{4}$ flux while the extratropics increase, with both latitude bands showing large differences between models (Table 5). Excluding the results of IAP-RAS gives the tropics a larger mean decrease in $\mathrm{CH}_{4}$ flux $(-18.0 \pm 13.0 \%)$, while the extratropics mean response becomes neutral $(3.2 \pm 25.4 \%)$. It is difficult to determine if the tropical decrease is a realistic response. Increased SAT can cause water stress/drought for the vegetation; however this water stress should not necessarily have an impact upon the vegetation growing in wetland areas (as they could still have standing water conditions), but the models are not able to distinguish this effect. Presently, most of the models that simulate tropical wetlands do not separately treat wetland vs. terrestrial hydrology. A separate treatment of wetland vs. terrestrial hydrology would also improve $\mathrm{CH}_{4}$ flux simulation because processes such as inhibition of soil respiration under saturated conditions could be better captured (Sulman et al., 2012). Interestingly, DLEM, the only WETCHIMP model that does separate wetland vs. terrestrial hydrology, simulates the largest negative tropical $\mathrm{CH}_{4}$ flux anomaly of all the models. The same reasoning could also apply for sub-grid treatment of methanogenesis substrate. For example, ORCHIDEE partially allows for sub-grid treatment of hydrology through its coupling to TOPMODEL concepts. However, 
Table 5. Percent change between the sensitivity tests $\left(\mathrm{CO}_{2}\right.$ increase - Experiment 4; air temperature increase - Experiment 5; and precipitation increase - Experiment 6) and the equilibrium model state (Experiment 1 - Equilibrium). "n.a." indicates the model does not produce output for that region or variable.

\begin{tabular}{|c|c|c|c|c|c|c|c|c|c|c|c|c|}
\hline \multirow[b]{2}{*}{ Model } & \multicolumn{4}{|c|}{ 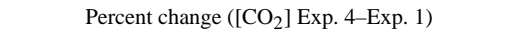 } & \multicolumn{4}{|c|}{ Percent change (Temperature Exp. 5-Exp. 1) } & \multicolumn{4}{|c|}{ Percent change (Precipitation Exp. 6-Exp. 1) } \\
\hline & $\begin{array}{r}\text { Wetland } \\
\text { area }\end{array}$ & Global & $\begin{array}{c}\mathrm{CH}_{4} \\
\text { Tropics }^{\mathrm{a}}\end{array}$ & Extratropics ${ }^{b}$ & $\begin{array}{r}\text { Wetland } \\
\text { area }\end{array}$ & Global & $\begin{array}{l}\mathrm{CH}_{4} \\
\text { Tropics }^{\mathrm{a}}\end{array}$ & Extratropics ${ }^{\mathrm{b}}$ & $\begin{array}{r}\text { Wetland } \\
\text { area }\end{array}$ & Global & $\begin{array}{r}\mathrm{CH}_{4} \\
\text { Tropics }^{\mathrm{a}}\end{array}$ & Extratropics ${ }^{b}$ \\
\hline LPJ-Bern & 9.5 & 54.0 & 61.1 & 39.0 & -1.9 & -0.7 & -11.5 & 21.1 & 1.3 & 1.3 & 1.1 & 1.4 \\
\hline CLM4Me & 8.5 & 84.2 & 54.1 & 147.3 & -8.9 & -25.3 & -19.9 & -37.0 & 2.6 & 6.8 & 5.8 & 8.8 \\
\hline DLEM & 2.2 & 22.4 & 29.1 & 14.0 & -2.8 & -15.1 & -40.9 & 24.5 & 1.4 & 2.2 & 1.3 & 4.3 \\
\hline IAP-RAS ${ }^{c}$ & n.a. & n.a. & n.a. & n.a. & n.a. & 36.9 & 32.9 & 47.8 & n.a. & 0.0 & 0.0 & 0.1 \\
\hline LPJ-WHyMe & n.a. & n.a. & n.a. & 40.1 & n.a. & n.a. & n.a. & 24.1 & n.a. & n.a. & n.a. & 6.9 \\
\hline LPJ-WSL $^{\mathrm{d}}$ & n.a. & 76.3 & 87.8 & 44.1 & n.a. & -8.1 & -11.1 & -0.5 & n.a. & 0.6 & 0.5 & 1.2 \\
\hline ORCHIDEE & 8.6 & 162.0 & 176.6 & 118.2 & -18.7 & -21.8 & -21.5 & -26.1 & 5.0 & 13.7 & 14.6 & 10.4 \\
\hline SDGVM & 0.3 & 40.1 & 46.2 & 26.7 & -7.4 & 2.3 & -3.3 & 16.6 & 2.0 & 7.6 & 9.4 & 3.2 \\
\hline UVic-ESCM ${ }^{\mathrm{e}}$ & 12.7 & n.a. & n.a. & n.a. & -7.4 & n.a. & n.a. & n.a. & 2.3 & n.a. & n.a. & n.a. \\
\hline $\begin{array}{l}\text { Mean } \pm 1 \sigma \\
(n)\end{array}$ & $\begin{array}{r}7.0 \pm 4.7 \\
(6)\end{array}$ & $\begin{array}{r}73.2 \pm 49.1 \\
(6)\end{array}$ & $\begin{array}{r}75.8 \pm 53.0 \\
(6)\end{array}$ & $\begin{array}{r}61.3 \pm 50.5 \\
\text { (7) }\end{array}$ & $\begin{array}{r}-7.9 \pm 6.0 \\
(6)\end{array}$ & $\begin{array}{r}-4.5 \pm 20.9 \\
(7)\end{array}$ & $\begin{array}{r}-10.8 \pm 22.6 \\
(7)\end{array}$ & $\begin{array}{r}8.8 \pm 28.3 \\
(8)\end{array}$ & $\begin{array}{r}2.4 \pm 1.4 \\
(6)\end{array}$ & $\begin{array}{r}4.6 \pm 5.0 \\
\text { (7) }\end{array}$ & $\begin{array}{r}4.5 \pm 3.8 \\
\text { (7) }\end{array}$ & $\begin{array}{r}4.7 \pm 5.6 \\
(8)\end{array}$ \\
\hline
\end{tabular}

a The tropics are defined here as $30^{\circ} \mathrm{S}$ to $30^{\circ} \mathrm{N}$.

b Extratropical region low latitude limit $\left(>35^{\circ} \mathrm{N}\right)$ chosen to coincide with the low latitude limit of peatland

distribution in Tarnocai et al. (2009) used by the LPJ-WHyMe model.

${ }^{\mathrm{c}}$ IAP-RAS is not sensitive to $\left[\mathrm{CO}_{2}\right]$, so we did not perform this experiment (see Eliseev et al., 2008; Wania et al., 2012). Additionally, IAP-RAS has fixed wetland extents.

${ }^{\mathrm{d}}$ LPJ-WSL has prescribed wetland extents from the GIEMS inundation dataset and are thus unchanging across the experiments.

${ }^{\text {e }}$ UVic-ESCM does not presently simulate $\mathrm{CH}_{4}$ emissions.

there is no ORCHIDEE PFT functioning as a true wetland PFT whose extent is linked to the diagnosed wetland fraction. Instead of this, the mean grid-cell soil labile carbon content is used to estimate the methanogenesis substrate, which makes the substrate overly sensitive to soil water modification.

ORCHIDEE simulated the greatest drop in wetland extent with an almost $20 \%$ decline. A similar response was noted for ORCHIDEE under a SRES A2 scenario by Ringeval et al. (2011). The largest areas of wetland loss for ORCHIDEE were in the high northern latitudes where there is a large increase during boreal summer in potential evaporation driving changes in the region's hydrologic regime.

Reduced $\mathrm{CH}_{4}$ emissions in the tropics could also be due to increased temperatures, in already very warm regions, resulting in a down-regulation of photosynthesis, decreasing NPP and reducing substrate available for $\mathrm{CH}_{4}$ production. This effect is likely to be important in relatively few regions and thus the broad tropical response is more likely due to water stress/drought as the dominant driver. Outside of areas with increased water stress/drought, the effect of increasing SAT should be to increase $\mathrm{CH}_{4}$ flux due to a direct enhancement of methanogenesis and an indirect effect via NPP. This effect is visible in parts of the high latitudes for many of the models (Fig. 9) (see also Koven et al., 2011). Across the extratropical region as a whole, while the models have no significant trend with a large range of up to $\sim 40 \%$ increase or decrease dependent upon the model, most models have enhanced $\mathrm{CH}_{4}$ emissions above $\sim 50^{\circ} \mathrm{N}$ in parts of Canada and Eurasia. The effect of model treatment of processes such as permafrost dynamics, snow pack, and surface runoff influence the results in these regions heavily. Areas that lose underlying permafrost have enhanced drainage resulting in drier soils less conducive to $\mathrm{CH}_{4}$ production. This effect is primarily responsible for the $\mathrm{CH}_{4}$ flux patterns simulated by CLM4Me, while this effect is not captured by LPJ-Bern whose wet mineral soils expand due to thaw activation of soil processes. As IAP-RAS does not allow changes to its hydrology due to increased SAT, the response of IAP-RAS in the higher latitudes is demonstrating the influence of temperature solely.

Attributing differences in the model $\mathrm{CH}_{4}$ flux anomalies to particular model parameters, such as $\mathrm{CH}_{4}$ production $\mathrm{Q}_{10}$ values, is difficult due to confounding effects of simultaneous changes to wetland extents, land surface characteristics (such as permafrost, snow cover, and vegetation dynamics), NPP, and $\mathrm{CH}_{4}$ production and oxidation rates.

\subsubsection{Sensitivity of $\mathrm{CH}_{4}$ emissions and wetland area to increased precipitation}

The models' response to the precipitation increase sensitivity test is uniformly low with global wetland areal extent increasing modestly $(2.4 \pm 1.4 \%)$ (Table 5$)$. This increase is the smallest of the sensitivity tests, and all models show a smaller percent change in wetland area than the step increase in precipitation $(+3.9 \%)$ except for ORCHIDEE. While the globally uniform spatial pattern of increase in precipitation is not realistic, this demonstrates that there is not a simple $1: 1$ relationship between precipitation and predicted global wetland extent.

The global mean simulated change in $\mathrm{CH}_{4}$ emissions is an increase that, while not significant, is observed in all of the models (Table 5). This increase is also evident in the tropics and boreal regions. The least and most sensitive models are again IAP-RAS and ORCHIDEE, respectively. IAPRAS, due to its prescribed hydrology, shows no response to precipitation changes, as would be expected. The general pattern of increased $\mathrm{CH}_{4}$ emissions with increased precipitation is related directly to two main processes. The first is a simple 


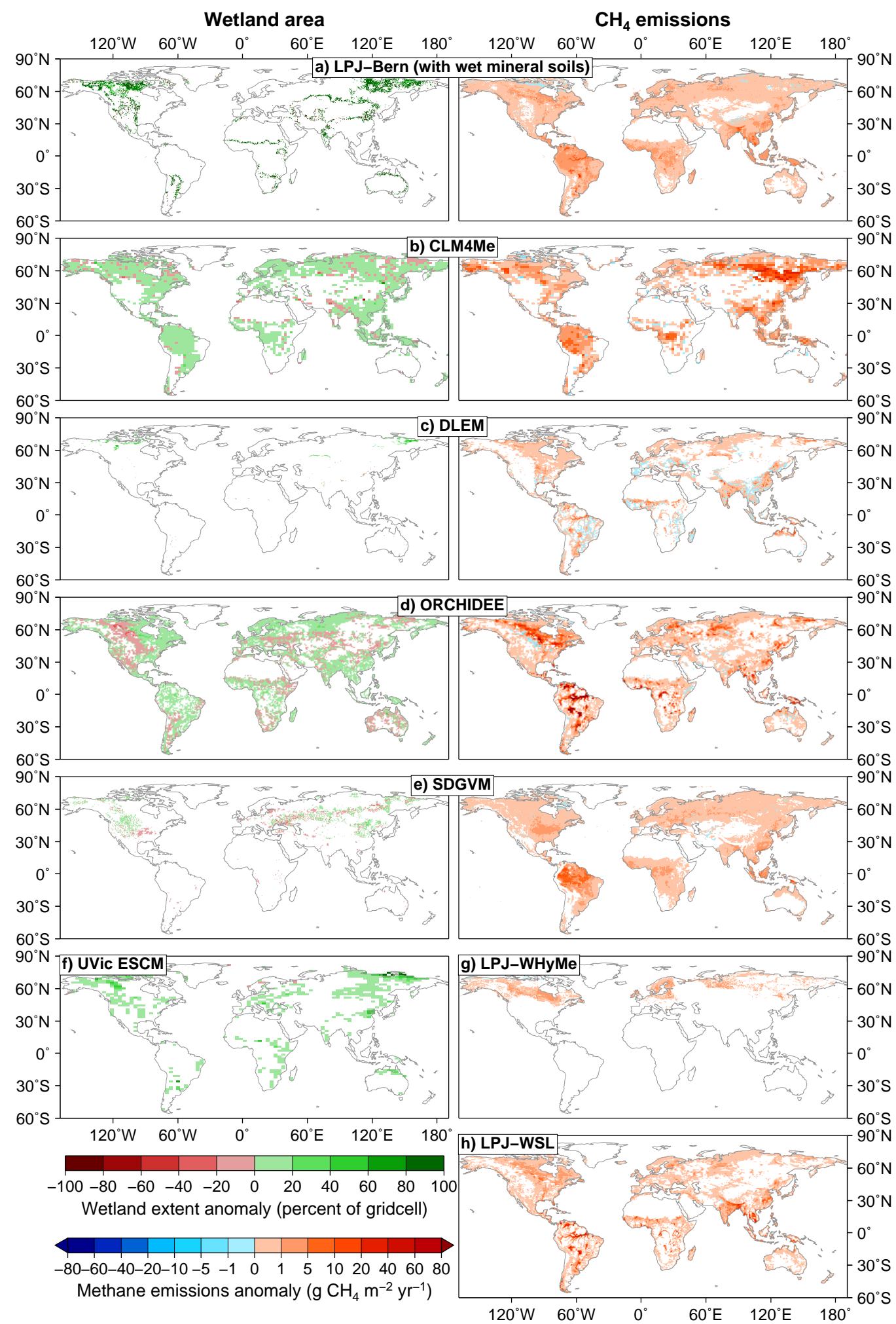

Fig. 8. Model wetland areas and $\mathrm{CH}_{4}$ flux anomalies from the model state with elevated atmospheric $\left[\mathrm{CO}_{2}\right]($ Experiment 4$)$ compared to the equilibrium simulation (Experiment 1). Methane flux anomalies are referenced to grid cell $\mathrm{m}^{2}$. 


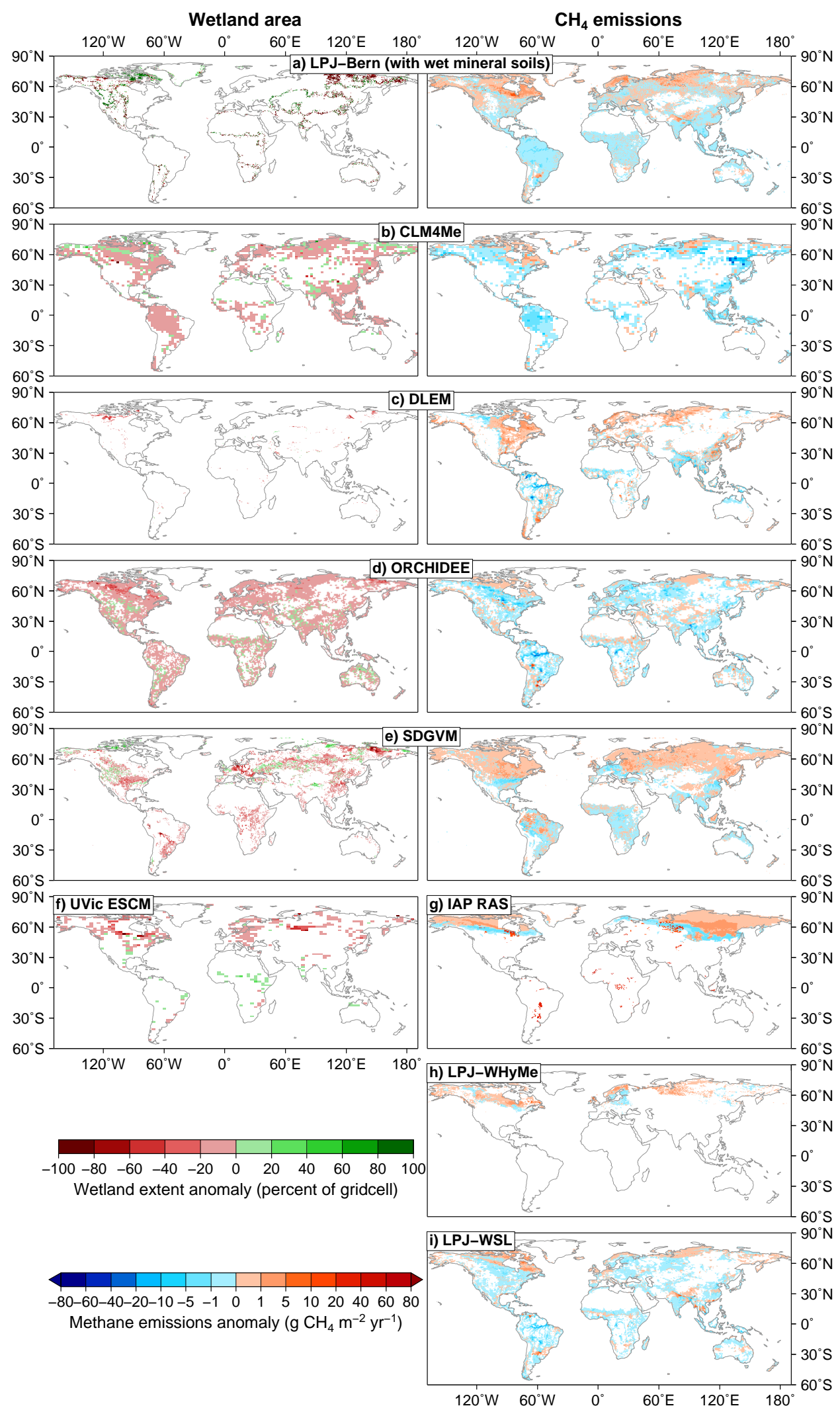

Fig. 9. Model wetland areas and $\mathrm{CH}_{4}$ flux anomalies from the model state with a uniform $3.4{ }^{\circ} \mathrm{C}$ increase in air temperature (Experiment 5) compared to the equilibrium simulation (Experiment 1 - Equilibrium) Methane flux intensities are referenced to grid cell $\mathrm{m}^{2}$. 
increase in wetland extent due to higher water table position (WTP). The second is due to higher WTP reducing the oxic portion of the soil column, thus decreasing oxidative loss of $\mathrm{CH}_{4}$ during transport from the site of methanogenesis to the atmosphere. In areas that are water-limited, the increased precipitation could increase NPP of the vegetation because of reduced water stress. This process is minor and mostly related to unrealistic modelling of terrestrial hydrology for wetland locations (discussed in Sect. 3.3.2).

\subsubsection{Combined impacts of $\left[\mathrm{CO}_{2}\right]$, SAT, and precipitation change}

In WETCHIMP, we did not perform tests for the combined effect of $\left[\mathrm{CO}_{2}\right]$, SAT, and precipitation change; however we can compare the relative contributions of these three drivers. The strongest response in modelled $\mathrm{CH}_{4}$ emission is due to $\mathrm{CO}_{2}$ fertilization. If the increase in $\mathrm{CH}_{4}$ due to $\mathrm{CO}_{2}$ fertilization is of similar magnitude to our models' mean, this represents a very strong feedback to rising levels of atmospheric $\mathrm{CO}_{2}$. Because of this strong feedback, the relative importance of $\mathrm{CH}_{4}$ in global climate forcing may increase. The response of the wetland systems will, however, likely be tempered by increasing SAT, which generally causes a reduction in global methane production. Precipitation has a smaller influence, but our test is likely poorly representative of how global wetlands will respond to a more spatially heterogeneous change in global precipitation.

Our transient simulation does allow some insight into simulated wetlands' response to relatively small changes in SAT and precipitation. The models' mean $\mathrm{CH}_{4}$ emissions increase of $\sim 5 \%$ (relative to 1997) in record-breaking hot, and wet, 1998 but little response to other similarly hot, but dry, years (2002 and 2003) demonstrates the effect of the climate drivers working in tandem. The possibility of non-linear effects, as all three of these drivers $\left(\left[\mathrm{CO}_{2}\right], \mathrm{SAT}\right.$, and precipitation) change into the future, greatly increases uncertainty of any projections based on the sensitivity tests presented here.

Other sources of uncertainty include processes in the models that are poorly represented, missing, or even incorrectly represented. For example, Sulman et al. (2012) demonstrated that observed gross ecosystem productivity (GEP) and ecosystem respiration (ER) for fens were higher during dry periods than wet periods. A suite of wetland models run for the three sites studied predicted either the opposite relationship or no significant difference. The incorrect response of the models was suggested to be due to model treatment of hydrology (not wetland-specific) and a lack of inhibition of GEP and ER under saturated conditions.

While not especially apparent in earlier simulations, the differences in model complexity are more apparent in our sensitivity tests. The response of the models to increased SAT in the boreal regions especially demonstrates the marked difference between models that resolve permafrost dynamics (CLM4Me, UVic-ESCM, LPJ-Bern, LPJ-WHyMe, OR-
CHIDEE) against those that do not (SDGVM, DLEM, IAPRAS, LPJ-WSL). This is also evident in the $\mathrm{CH}_{4}$ flux response of IAP-RAS, the most simplistic model, to increased SAT, as the model hydrology can not adapt to the increased water demand and thereby simulates an erroneously high $\mathrm{CH}_{4}$ flux increase. Gaining complexity in a model does come with risk. Models that attempt to represent mechanistic detail require more parameters, more representation of related processes (such as $\mathrm{O}_{2}$ concentrations), and a more detailed representation of spatial heterogeneity. However, for many parameters used in these models (e.g. $V_{\max }$ and $K_{\mathrm{m}}$ for oxidation, aerenchyma area, diffusivity, seasonal dynamics), there simply is not enough data to properly constrain them across the globe (Riley et al., 2011). Therefore, increased model complexity can result in problems associated with equifinality of parameterizations (Tang and Zhuang, 2008), raising legitimate questions about the value of increased model complexity and stressing the importance of a balance between capturing the important processes, but as simply as possible.

\section{Conclusions}

Ten large-scale wetland and wetland $\mathrm{CH}_{4}$ models participated in the WETCHIMP. The models cover a wide-range of complexity in their parameterizations to mechanistically determine wetland extent and associated $\mathrm{CH}_{4}$ fluxes. Model results presented here include a transient simulation, forced with observed climate and $\left[\mathrm{CO}_{2}\right]$ through 1993 to 2004, as well as three sensitivity tests run as equilibrium simulations for increased $\left[\mathrm{CO}_{2}\right]$, surface air temperature (SAT), and precipitation.

The participating models adopted three distinct approaches to estimating wetland location and extent: prescribed extents, parameterization/forcing with a remotely sensed inundation dataset, or independent wetland location determination via a hydrological model. The models' simulated wetland extents have an almost four-fold difference between the lower and upper estimates $\left(8.6\right.$ to $26.9 \times 10^{6} \mathrm{~km}^{2}$, excluding the models with prescribed extents and the wet mineral soils of LPJ-Bern). This degree of uncertainty is only slightly worse than literature estimates from inundation and wetland mapping sources, which vary three-fold (4.3 to $12.9 \times 10^{6} \mathrm{~km}^{2}$ ). The models independently determining wetland location via their hydrologic model simulated larger wetland extents than those informed by inundation datasets. The latter models were also more in line with observational estimates of global wetland extents, but those observational datasets have several discrepancies that make their use problematic. Given the disagreements between inundation and wetland mapping datasets, it appears that model reliance upon inundation datasets does not ensure accurate wetland location determination, and underlines a need for improved accuracy in observational datasets. 
The participating models' wetland zonal extents have best agreement amongst themselves in the high northern latitudes above $45^{\circ} \mathrm{N}$, but poor agreement in the equatorial band. The seasonal dynamics of wetland extent also show wide-spread disagreement between the models, save a general pattern of higher global wetland extent in the boreal summer. The simulated months, and peak magnitudes, of global wetland extent also vary greatly between the models. Across the transient simulation (1993-2004), the models simulate no trend in global wetland extent, at odds with a reported decrease in global remotely sensed inundation (Papa et al., 2010).

Simulated global $\mathrm{CH}_{4}$ flux estimates by the participating models (141 to $264 \mathrm{TgCH}_{4} \mathrm{yr}^{-1}$ with a mean value of $190 \mathrm{TgCH}_{4} \mathrm{yr}^{-1}$ ) are in-line with literature forward and inverse model values. Given the large range encompassed by the WETCHIMP model estimates ( $\sim 40 \%$ of the models' mean), we are not able to greatly reduce the uncertainty of global wetland $\mathrm{CH}_{4}$ estimates.

To further evaluate our simulation results, we require observation datasets at appropriate spatial and temporal scales for the coarse resolution of global-scale models. The common use of intermittent and spatially non-representative chamber-based observations, without ancillary ecosystem measurements (see, e.g. Bartlett and Harriss , 1993), is insufficient to test the mechanistically complex models used for global $\mathrm{CH}_{4}$ emission estimates. As pointed out by Riley et al. (2011), it is possible to simulate the fluxes well for a given location, but with incorrect contributing processes, such as production, oxidation, or transport. Therefore, there is a need for site-level observations of both $\mathrm{CH}_{4}$ fluxes and the physical and biogeochemical state variables associated with the large range of mechanisms represented in these types of models (e.g. NPP, labile carbon production, soil temperature, water content, water table position, soil depth, plant species present, $\mathrm{CH}_{4}$ and $\mathrm{O}_{2}$ content in soil, soil $\mathrm{pH}$, etc.). The observations need to occur at sufficient frequency to resolve rapid, random events (i.e. ebullition); occur over a long enough time to capture seasonal dynamics in substrate production, aerenchyma changes, etc.; and accurately capture the impacts of spatial heterogeneity. Studies with site-level observations are well suited for evaluating model components and ensuring that the model simulations of processes such as $\mathrm{CH}_{4}$ production and oxidation are appropriate. Inclusion of modellers in designing measurement protocols for a sampling campaign could be of great value. Areas of priority could include the equatorial band and parts of South America extending down into the Pampas region. Recent work in this region by Beck et al. (2012) is encouraging. The climate space of global wetlands could also provide guidance for effectively filling data and knowledge gaps, by collecting data from wetlands across the full spectrum of wetland temperature and precipitation regimes. Expanding beyond largescale observational datasets, an inter-comparison of inverse $\mathrm{CH}_{4}$ models could be useful for information about the latitudinal gradient of $\mathrm{CH}_{4}$ emissions. Further WETCHIMPs could also be used for more in-depth comparison of the underlying processes of wetland determination and $\mathrm{CH}_{4}$ emission, given careful planning of project experiments.

The current paucity of appropriate observational datasets presents a large obstacle to improving our understanding and ability to model global wetlands. For one of the few wellstudied large regions, the Hudson Bay Lowlands, many of the WETCHIMP models appear to overestimate $\mathrm{CH}_{4}$ emissions, sometimes several-fold over observationally based estimates.

As expected, given the wetland extent modelling results, the models disagree in the relative timing of $\mathrm{CH}_{4}$ fluxes throughout the year, as they do for wetland extent. The demonstrated close correlation between wetland extent and $\mathrm{CH}_{4}$ emissions (models' mean global $\rho$ value of 0.898) makes it evident that errors in the wetland extent propagate to the $\mathrm{CH}_{4}$ emissions simulated. Indeed, as the wetland $\mathrm{CH}_{4}$ models themselves are integrated into vegetation models, they are susceptible to the biases in the vegetation models for variables such as net primary productivity, soil physics and hydrology, and vegetation dynamics.

The three sensitivity tests show a strong sensitivity of the models to increased $\left[\mathrm{CO}_{2}\right]$ (increase in $\mathrm{CH}_{4}$ and wetland area), a more mixed and moderate response to increased SAT (decrease in global wetland area and decrease in tropical $\mathrm{CH}_{4}$ emissions), and a weak response to increased precipitation (increase in global wetland extent and $\mathrm{CH}_{4}$ emissions). It is worth noting that all models responded with an increase in wetland area and $\mathrm{CH}_{4}$ emissions under elevated $\left[\mathrm{CO}_{2}\right]$, while the other two sensitivity tests yielded more divergent model responses. It is likely the magnitude of the model response to $\left[\mathrm{CO}_{2}\right]$ is overestimated due to missing models processes (such as NPP nutrient limitations, wetland specific hydrology and vegetation, etc.), but the direction of change appears robust.

This study clearly demonstrates that to reduce the large uncertainties in wetland response to projected climate change further work is needed to better parameterize and evaluate the models. The large range in predicted $\mathrm{CH}_{4}$ emission rates leads to the conclusion that there is substantial parameter and structural uncertainty in large-scale $\mathrm{CH}_{4}$ emission models, even after uncertainties in wetland areas are accounted for. Of paramount importance for improving the models is increases in availability of accurate and suitable observational datasets of both wetland extent and $\mathrm{CH}_{4}$ emissions at large spatial scales. Further inter-comparisons of the models will aid our understanding of which natural processes are key to making large improvements in model accuracy. The results of this first iteration of WETCHIMP are designed to be a baseline, on which further improvements can be gauged and priorities identified. 


\section{Appendix A}

\section{A1 Wetland variability by model}

CLM4Me shows substantial intra- but little inter-annual variability with a peak global wetland extent starting in June and continuing into August/September (Fig. 2a). Here CLM4Me is responding only to climate changes across this period as the $\left[\mathrm{CO}_{2}\right]$ was held constant (this is the only model with constant $\left[\mathrm{CO}_{2}\right]$ ). For CLM4Me, the boreal summer is an important control of global wetland area, with their simulated wetland extent dropping off quickly after September. The lowest simulated global wetland extent in the boreal winter months across all models is simulated by CLM4Me with an average value under $2 \times 10^{6} \mathrm{~km}^{2}$ in December/January. This pattern is likely an artefact of the modelling scheme as the modelled inundated areas are set to zero when the ground freezes (Riley et al., 2011). CLM4Me also has the fastest relative rate of increase in global wetland area during the boreal spring (Fig. 2g). The general pattern of rapid boreal spring wetland expansion and boreal autumn wetland contraction is also seen in SDGVM (Fig. 2e).

DLEM fixes the annual maximal wetland extent of each year to that from the GIEMS dataset; thus, the annual maximal values are not independent of this dataset. However, the intra-annual variability is calculated within the model and shows low variability with a broad peak in maximum wetland extent consistently around July and with a minimum in February (Fig. 2b). The duration of elevated global wetland extent is the longest of all models with a consistent six month period of relatively high wetland extents spanning May to October.

The largest maximal wetland areal extent of all models is simulated by LPJ-Bern with a peak extent of $\sim 25 \times 10^{6} \mathrm{~km}^{2}$, although this does include their wet mineral soils parameterization (Fig. 2c). The LPJ-Bern timing of minimum global wetland/wet soils area occurs in May, which is in contrast to the other models that generally show a boreal winter minimum, with the exception of UVic-ESCM (boreal autumn minimum). The intra-annual wetland extent dynamics of LPJ-Bern are evidently heavily controlled by the wet mineral soils parameterization as the inundated wetlands and peatlands, which are also considered by LPJ-Bern, follow the GIEMS dataset or are static, respectively. The wet mineral soils parameterization appears to almost have a bimodal distribution for monthly maximal wetland extent with a peak in August/September and a smaller peak in February/March. This unique seasonal pattern highlights the fundamental differences between the parameterization of "wetland/inundated" areas and wet mineral soils as determined by LPJ-Bern.

ORCHIDEE consistently has a small annual peak in wetland extent with a maximum extent of only $\sim 5 \times 10^{6} \mathrm{~km}^{2}$ (Fig. 2d), only slightly smaller than CLM4Me. The pattern of ORCHIDEE simulated wetland extent is generally consis- tent with CLM4Me and SDGVM, giving a maximal wetland extent around July and a minimum around December. The relative difference between maximum and minimum wetland extents is, however, lower for ORCHIDEE than CLM4Me, SDGVM and GIEMS (Fig. 2g).

SDGVM has more variability in months of maximal and minimum wetland extents compared to most of the other models with the maximal extent occurring between June and August and the minimum extent in either February or November (Fig. 2e). The variability is a reflection of the binary nature of the model parameterization where the grid cell has either total or no wetland extent. That simple parameterization does not preclude SDGVM from fairly closely following the annual pattern of the GIEMS inundation dataset (Fig. 2g), although the inundation dataset peak occurs principally in August while the SDGVM peak occurs on average between June and August. SDGVM likely can have peak wetland extent earlier due to its lack of freezing soils.

UVic-ESCM has an annual pattern strongly contrasting to that of the SDGVM and the GIEMS datasets, and almost antiphase to LPJ-Bern. The annual global peak in wetland area is simulated to occur in May to June, but wetland extents are elevated generally from January through July. UVic-ESCM is similar to SDGVM with relatively higher variability in timing of the month of minimum/maximum wetland extents. UVic-ESCM and LPJ-Bern are the lone models to show elevated wetland extents in the boreal winter though the reasons behind this pattern differ. A large portion of the UVic-ESCM wetland extent comes from the tropical regions, where the model results are likely questionable for reasons discussed earlier. However, as LPJ-Bern's global wetland extent pattern is principally driven by its wet soils parameterization, the similarity between the two models demonstrates that the UVic-ESCM parameterization functions similarly to the wet mineral soils of LPJ-Bern, but UVic-ESCM does include a topographic criteria that is not part of the LPJ-Bern parameterization. The timing of changes in UVic-ESCM wetland extent in the boreal regions follows those of the other models and the GIEMS dataset much more closely (see discussion in Sect. 3.1.2).

Monthly zonally averaged wetland area plots for 1993 to 2004 are shown in Fig. A2. CLM4Me has a pattern of extensive boreal summer wetlands above $60^{\circ} \mathrm{N}$ with no wetlands evident outside of the summer months (Fig. A2a), similar to the pattern simulated by SDGVM (Fig. A2e) and UVic-ESCM (Fig. A2f). This pattern is also observed by the GIEMS dataset (Fig. A2g), although this could be influenced by the snow cover mask used in generating the dataset.

The lack of wetlands outside of summer months for CLM4Me is related to the parameterization of no wetlands: (1) if there is snow on the ground, or (2) if the soil temperature is below freezing. Outside of the boreal regions, CLM4Me shows relatively little variation inter- and intraannually for latitudinal bands centred around $30^{\circ} \mathrm{N}$ and the equator. An equatorial band with little variation in wetland 


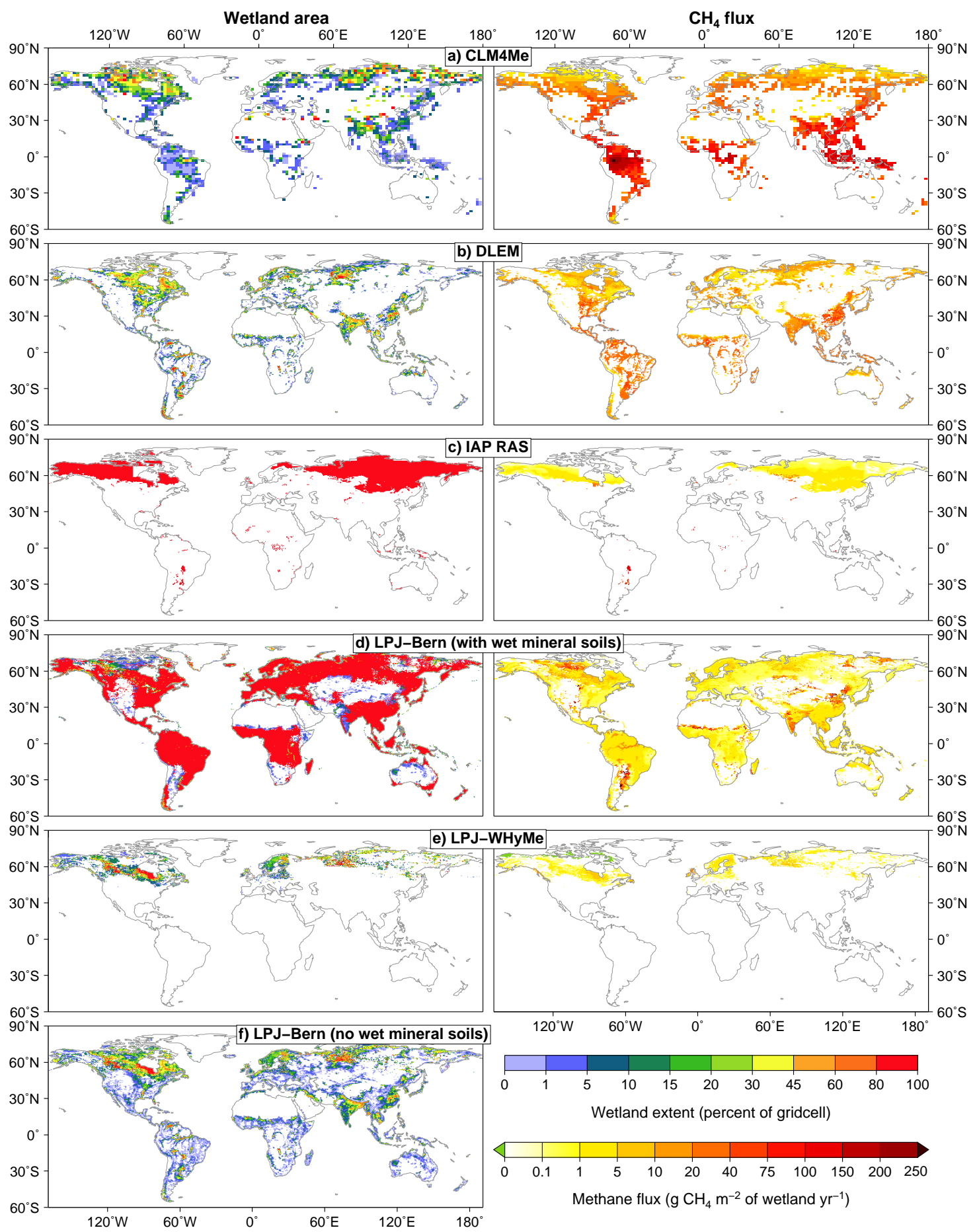

Fig. A1. Maximal wetland extent and mean annual $\mathrm{CH}_{4}$ flux densities for Experiment 1 for all models.

extent is a characteristic shared with DLEM (Fig. A2b). DLEM, however, does simulate a much stronger seasonal cycle in the $10^{\circ} \mathrm{N}-30^{\circ} \mathrm{N}$ latitudinal band and also has a weaker seasonal cycle in the Northern Hemisphere boreal regions. DLEM and ORCHIDEE (Fig. A2d) overall share many similarities in their wetland extent patterns, with only slight dif- ferences such as a broader boreal summer wetland extent peak in DLEM and a more seasonally varying equatorial wetland extent simulated by ORCHIDEE.

LPJ-Bern has wetland areas at all latitudes during all periods of the year. The high latitude winter wetland areas in Fig. A2c are prescribed peatlands. The variability 


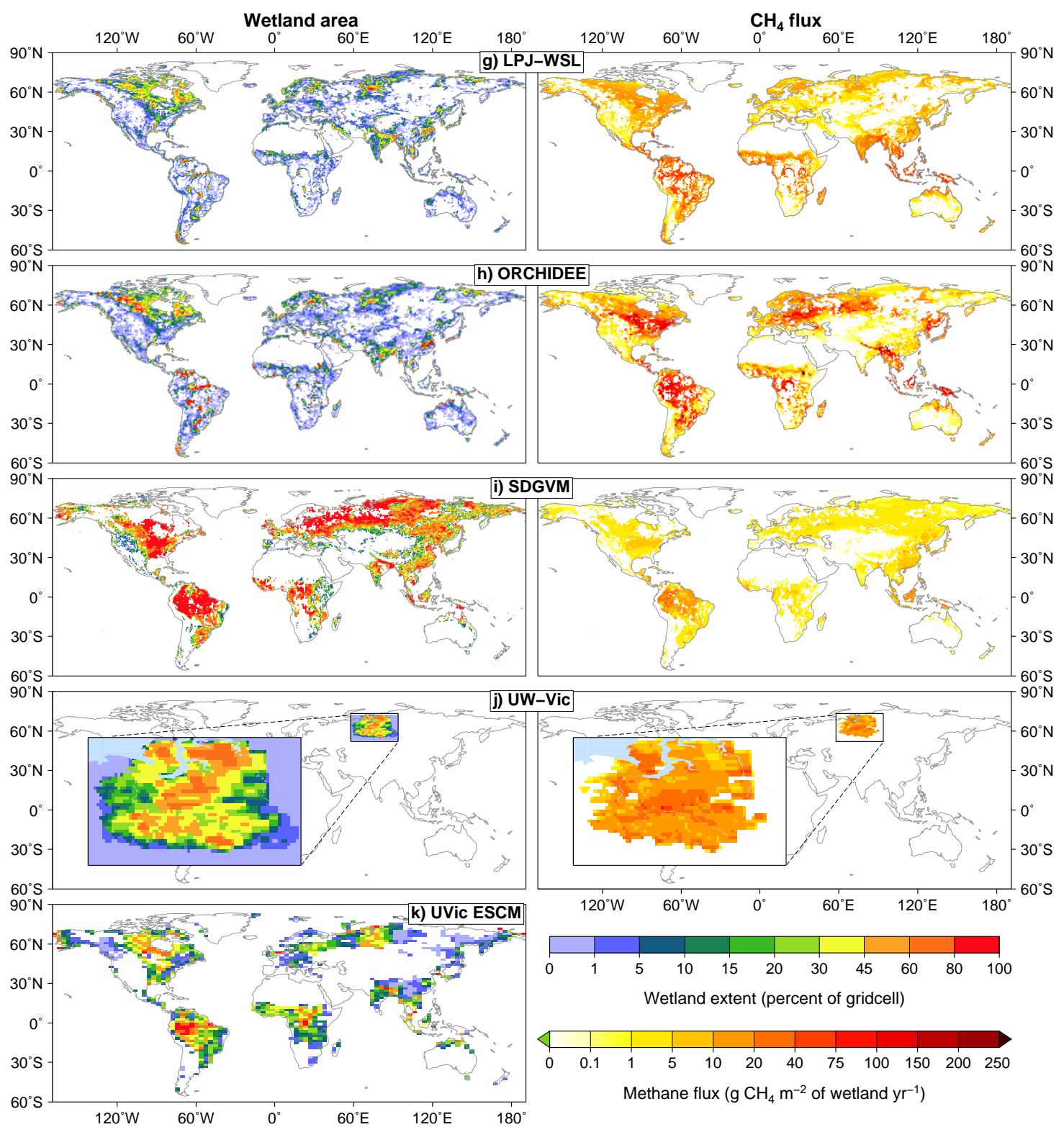

Fig. A1. Continued.

in "wetland" extent for LPJ-Bern was determined based upon $\mathrm{CH}_{4}$ emissions. This was to allow a consistent definition of "wetland" for comparison as the model also simulates wet mineral soils, inundated wetlands, and peatlands. The peatland area in reality is constant, but the area of methane emissions in peatlands is varying. During the winter, some small $\mathrm{CH}_{4}$ emissions could occur (on the order of $0.01 \mathrm{~g} \mathrm{CH}_{4} \mathrm{~m}^{-2}$ month $^{-1}$ ) making these grid cells appear as wetlands. The LPJ-Bern wetland/wet soils peak extent traces a rapid rise at the start of the boreal summer with a more gradual decline with latitude as the boreal summer ends. In the tropical regions, LPJ-Bern has a strong seasonal cycle of wetland/wet soils area with high extents in the south- ern tropics during the austral summer and high extents in the northern tropics during the boreal summer. The seasonal pattern simulated by LPJ-Bern shares some characteristics with SDGVM and UVic-ESCM. Both SDGVM and UVicESCM show strong seasonality in the tropics and subtropics, with both models following the patterns of precipitation in those regions. Interestingly, the GIEMS dataset does not show a strong seasonal cycle following precipitation patterns as evident in LPJ-Bern, SDGVM and UVic-ESCM. Both SDGVM and UVic-ESCM additionally have strong peaks in the boreal summer with little to no wetlands during the winter at latitudes as low as $40^{\circ} \mathrm{N}$. Given the close resemblance between UVic-ESCM and the GIEMS dataset for the boreal 
regions, it appears correct to assume that the dominant driver of the global pattern of wetland extent for UVic-ESCM in Fig. $2 \mathrm{f}$ is the model's tropical regions. Interestingly, while SDGVM does not have freezing soils, it has a similar temporal pattern to UVic-ESCM, but has generally higher percent wetlands at the same latitudes. SDGVM could be simply responding to the general summer peak in precipitation at these latitudes, particularly as the wetland area was constrained under two conditions: (1) the monthly air temperature must be above $5^{\circ} \mathrm{C}$, and (2) if the temperature in a given grid cell during the current year is always greater than $0{ }^{\circ} \mathrm{C}$, then in a given month the evapotranspiration must not exceed precipitation.

\section{A2 Methane fluxes by model}

CLM4Me has high $\mathrm{CH}_{4}$ flux intensity in the tropics, primarily the Amazon, Congo, and Indonesia, and in the boreal regions near the eastern Russia-China border, and the West and Central Siberian lowlands (Fig. 4a). These hotspots of $\mathrm{CH}_{4}$ emissions are visible in the meridional and zonal emission sums (which account for the actual wetland extent per latitude/longitude band). The peak around latitudes $20^{\circ}-30^{\circ} \mathrm{N}$ is an area of intense rice agriculture. These rice paddies have not been masked from the CLM4Me outputs. The intense tropical $\mathrm{CH}_{4}$ fluxes, in part, result from a well-known tropical NPP bias in CLM4Me (Bonan et al., 2012) providing large amounts of substrate for methanogenesis. These emissions from CLM4Me could be biased low due to the model seeing a constant $\left[\mathrm{CO}_{2}\right]$ of $303 \mathrm{ppm}$ (it is the only model without an evolving $\left[\mathrm{CO}_{2}\right]$ in this experiment).

The DLEM model has a more diffuse pattern of methane emissions than CLM4Me with a lower $\mathrm{CH}_{4}$ flux intensity (Fig. 4b). The $\mathrm{CH}_{4}$ flux intensity map shows a large number of individual grid cells with high emissions intensity and little consistent pattern of high emission regions. China shows strong emissions in the extratropics, as well as the central Eastern US.

IAP-RAS has a meridional and zonal emissions pattern primarily influenced by its wetland distribution dataset (Fig. 4c). $\mathrm{CH}_{4}$ emissions intensity is generally low and not highly variable across much of the boreal region, with some notable exceptions in the HBL and areas of the southern West Siberian Lowlands where $\mathrm{CH}_{4}$ emissions intensity is almost an order of magnitude larger than the rest of the boreal region. This pattern relates to the differences in soil depth between peat and mineral soils in the model input datasets. IAP-RAS active layer thickness is heavily influenced by the thermophysical parameters of the peat or mineral soil, impacting upon the soil temperature and hydrology. IAP-RAS's $\mathrm{CH}_{4}$ emissions from the small amount of tropical and subtropical wetlands are of relatively high intensity and, since they are $100 \%$ wetland cover, have strong peaks in the zonal and meridional sum plots.
The wet mineral soils parameterization of LPJ-Bern gives zonal and meridional $\mathrm{CH}_{4}$ sum plots with broad peaks more similar to the results of DLEM than either IAP-RAS or CLM4Me (Fig. 4d). LPJ-Bern also accounts for rice agriculture, reducing the natural wetland emissions in these regions similar to DLEM. The wet mineral soils of LPJ-Bern do not contribute a large amount of $\mathrm{CH}_{4}$ as the areas of highest $\mathrm{CH}_{4}$ fluxes are those that were part of either the inundation, or peatland, datasets (see Fig. A1f). The LPJ-Bern areas of highest annual $\mathrm{CH}_{4}$ emissions intensity are the Pantanal, India, and eastern China. There are also areas of high $\mathrm{CH}_{4}$ emitting wetlands in north-central Africa that are part of the GIEMS inundation dataset. LPJ-Bern has strong boreal $\mathrm{CH}_{4}$ emissions in Northern Canada and Eastern Siberia. This intensity of $\mathrm{CH}_{4}$ emissions comes from inundated regions, as these areas are not prescribed as peatlands.

LPJ-WHyMe simulates a pattern of $\mathrm{CH}_{4}$ emissions unique from the global-scale models (Fig. 4e). High $\mathrm{CH}_{4}$ flux intensity is simulated for the British Isles by LPJ-WHyMe, a result not found by the other models. The climate of this region, as well as the Pacific coast of North America and the Atlantic coast of Europe, has mild winters that allow $\mathrm{CH}_{4}$ emissions to continue year-round, yielding high annual emissions intensity for LPJ-WHyMe.

LPJ-WSL shows a strong gradient between latitudes with tropical regions generally simulated with higher $\mathrm{CH}_{4}$ fluxes then decreasing relatively steadily poleward (Fig. 4f). This pattern is due to the model parameterization of $\mathrm{CH}_{4}$ flux as an exponential function of respiration that is sensitive to surface temperatures. Some zones of exception exist to this trend, primarily in the HBL and West Siberian lowland regions. The overall meridional and zonal patterns of $\mathrm{CH}_{4}$ fluxes of LPJ-WSL are most similar to ORCHIDEE. Spatially, ORCHIDEE $\mathrm{CH}_{4}$ flux density is more evenly distributed across wetland areas (Fig. 4g). ORCHIDEE simulates broad areas of strong $\mathrm{CH}_{4}$ emissions across the tropics, as well as the Ganges delta and eastern China. Boreal emissions are strongest across broad areas of the Northern US and Eastern Europe into Western Siberia. The use of an inundation dataset for model parameterization is also visible, giving a patchy appearance to areas such as the Amazon (see Fig. 1).

SDGVM has a much lower overall $\mathrm{CH}_{4}$ flux density, with the strongest $\mathrm{CH}_{4}$ emissions simulated in the Amazon region. This low $\mathrm{CH}_{4}$ flux density compensates for the high wetland extent simulated by the model. SDGVM has the smoothest pattern of meridional and zonal $\mathrm{CH}_{4}$ sums across all models (CLM4Me's predictions appear relatively smooth due to the coarse resolution of its grid cells), with its largest zonal peak in emissions at the equator and smaller secondary peaks for the Ganges delta and southern China, as well as a broad peak between about $40^{\circ}-60^{\circ} \mathrm{N}$. The meridional $\mathrm{CH}_{4}$ sum plot is dominated by a large peak representing the contribution from the Amazon River catchment. 


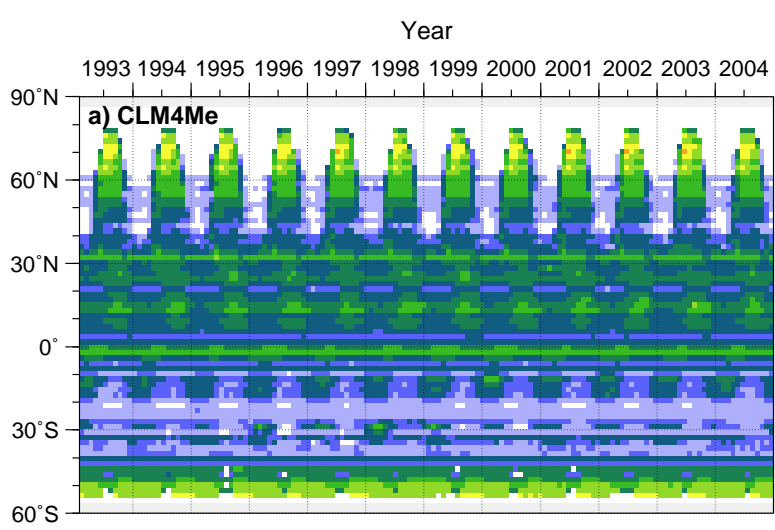

Year
199319941995199619971998199920002001200220032004
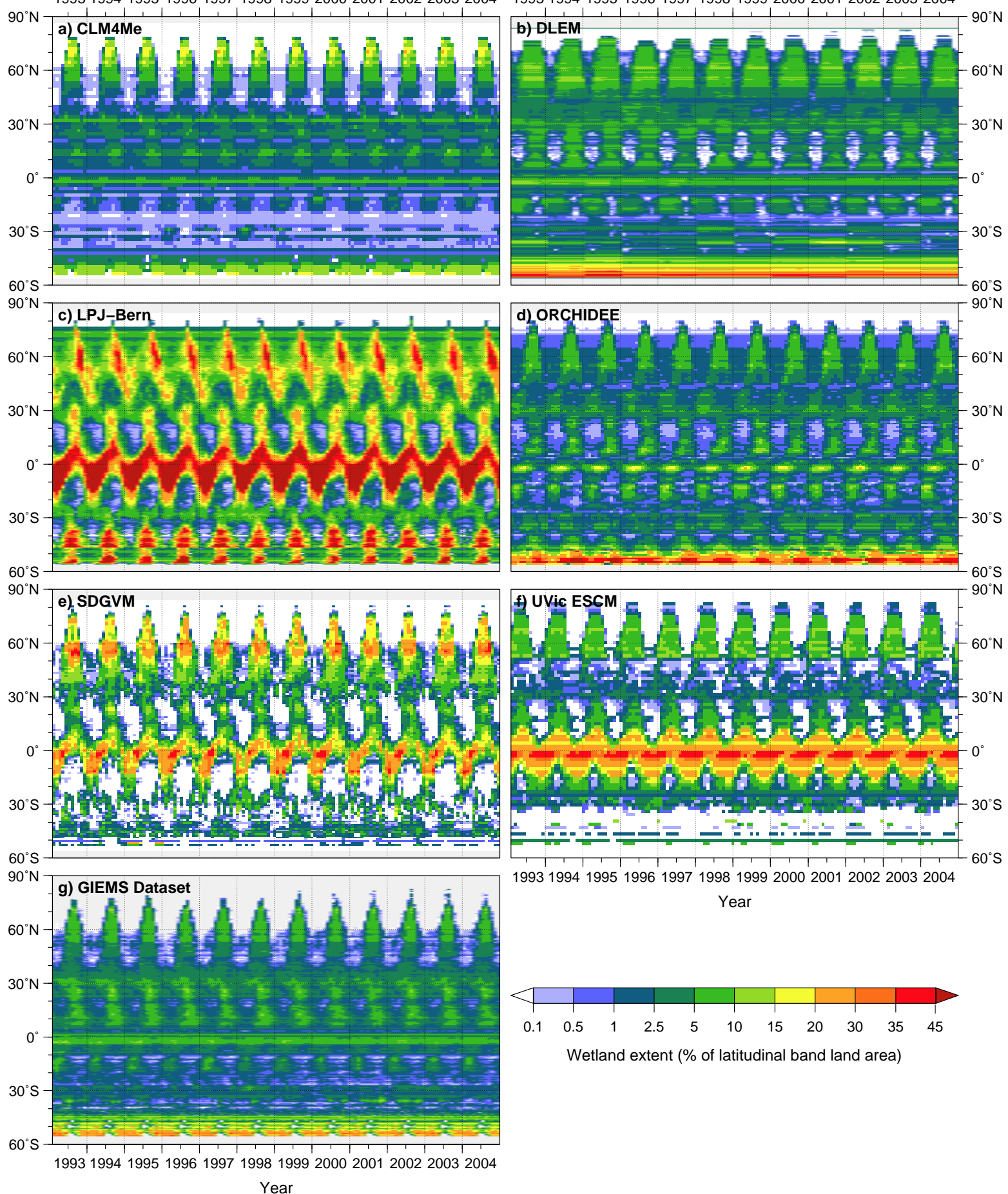

199319941995199619971998199920002001200220032004

Year

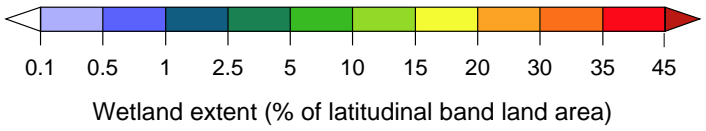

Fig. A2. Monthly zonally averaged wetland area for 1993-2004 for all models that have independent calculation of intra-annual variability. The inundation dataset, GIEMS, is included as an approximate observed wetland area.

When the wetland methane emissions are looked at dynamically, the seasonal timing and relative contributions from latitudinal bands to $\mathrm{CH}_{4}$ fluxes are highly variable be- tween the models (Fig. 6). CLM4Me has an early global peak in $\mathrm{CH}_{4}$ emissions driven by the boreal band $\left(40^{\circ}-90^{\circ} \mathrm{N}\right)$, appearing in June (Fig. 6a) and corresponding to their simulated 
Table A1. Listing of masks used to correct simulated wetland areas for non-natural wetland waterbodies per model. GICEW is the global land, ice and water mask from Hurtt et al. (2006).

\begin{tabular}{llll}
\hline \multirow{2}{*}{ Model } & \multicolumn{2}{c}{ Masking Applied } \\
& Major rivers & Large lakes & Rice agriculture \\
\hline LPJ-Bern & GICEW & GICEW & Leff et al. (2004) \\
CLM4Me & & & \\
DLEM & & & \\
IAP-RAS & n.a. & n.a. & n.a. \\
LPJ-WHyMe & n.a. & n.a. & n.a. \\
LPJ-WSL & & & Leff et al. (2004) \\
ORCHIDEE & & & Leff et al. (2004) \\
SDGVM & & & \\
UVic-ESCM & & & \\
UW-VIC & & & \\
\hline
\end{tabular}

maximal global wetland extent (Fig. 2a). CLM4Me simulates relatively small seasonality in the tropics $\left(30^{\circ} \mathrm{S}-30^{\circ} \mathrm{N}\right)$, with an intra-annual change on the order of $5 \mathrm{TgCH}_{4} \mathrm{yr}^{-1}$, consistent with the simulated relatively small change in wetland area (Fig. A2a). The much smaller maximum in northern subtropical $\left(20^{\circ}-40^{\circ} \mathrm{N}\right) \mathrm{CH}_{4}$ fluxes peaks later than boreal emissions (in July), although the entire annual range for this latitudinal band is also only about $5 \mathrm{TgCH}_{4} \mathrm{yr}^{-1}$.

DLEM has a distinctly different global $\mathrm{CH}_{4}$ flux pattern with peak emissions occurring in August (Fig. 6b), two months after CLM4Me, but again relatively consistent to the pattern of DLEM simulated wetland extent (Fig. 2b). As well, the main source of variation in the DLEM emissions peak is primarily driven by the tropical, boreal, and northern subtropical bands. The DLEM tropical band has a $\mathrm{CH}_{4}$ emissions peak in August, again two months after CLM4Me, but this peak is not obviously dependent upon wetland extent (Fig. A2b). LPJ-Bern simulates a global $\mathrm{CH}_{4}$ emissions peak in August, with a strong contribution from the boreal region in that month, but also strongly emitting from July into September (Fig. 6c). The LPJ-Bern tropical band also contributes with a broad boreal summer peak in emissions. This timing slightly leads the usual month of greatest wetland/wet soils extent, simulated by LPJ-Bern to be September (Fig. 2c). Given the pattern of LPJ-Bern $\mathrm{CH}_{4}$ emissions, it appears that the wet mineral soils are contributing small $\mathrm{CH}_{4}$ flux densities (but large areas) for much of the year (compare Fig. 6c to Fig. 2c), but with a roughly equal flux contributed by the inundated and peatland fractions.

LPJ-WSL shows an intermediate time for peak global $\mathrm{CH}_{4}$ emissions, peaking in July, with contributions fairly equally from the entire Northern Hemisphere (Fig. 6d). This pattern is due to the model parameterization responding to the gradient in surface temperature poleward. The model $\mathrm{CH}_{4}$ parameterization scales heterotrophic respiration by surface temperature and two latitudinal scaling factors to calculate $\mathrm{CH}_{4}$ flux densities (see description in Hodson et al., 2011; Wania et al., 2012). Like most models, LPJ-WSL shows a reasonably strong anticorrelation between the northern and southern tropical region $\mathrm{CH}_{4}$ fluxes, with the northern region's peak emissions occurring in the northern summer. This tropical $\mathrm{CH}_{4}$ flux anticorrelation pattern is also present in the results of CLM4Me, but it is the weakest of all the models. ORCHIDEE has a similar timing of peak global $\mathrm{CH}_{4}$ emissions, occurring in July, to LPJ-WSL (Fig. 6e). The ORCHIDEE global $\mathrm{CH}_{4}$ emissions peak is strongly driven by the northern boreal region. ORCHIDEE also has a strong $\mathrm{CH}_{4}$ flux cycle in the southern tropics, much stronger than that of the northern counterpart. SDGVM simulates a strong seasonal cycle of $\mathrm{CH}_{4}$ emissions in the southern tropical region (Fig. $6 \mathrm{f}$ ), while the largest driver of peak global emissions for SDGVM is the northern boreal region. SDGVM shares some similarity with ORCHIDEE in its $\mathrm{CH}_{4}$ flux pattern for the southern tropical band with a strong seasonal cycle of higher fluxes around March and lower fluxes around August to September.

Acknowledgements. The authors are grateful to the COST Action ES0805 TERRABITES for providing support for the WETCHIMP workshop. We thank Sylvia Houston and Olga Petrikova for assistance with organizing the project meeting and Kristen Krumhardt for assistance producing the figures. J. R. M. was supported by the Swiss Ministry for Research and Education (grant C09.0054). J. O. K. acknowledges support from the Swiss National Science Foundation (grant PP0022_119049 and PP00P2_39193). The contributions of W. J. R. and Z. M. S. were supported by the Director, Office of Science, Office of Biological and Environmental Research, Climate and Environmental Science Division, of the US Department of Energy under Contract No. DE-AC02-05CH11231 to Berkeley Lab (IMPACTS and C-Climate Uncertainties projects). The contributions of T. J. B. and D. P. L. were supported by NASA's ROSES program, grant NNX08AH97G. The contribution of Z. C. Y. was supported by a US NSF grant (ARC-1107981) and a grant from The Max Planck Society (Germany). A. V. E. and S. N. D. were supported by the the President of Russia grant 5467.2012.5, by the Russian Foundation for Basic Research, and by the programs of the Russian Academy of Sciences. The contributions of R. S. and S. Z. were supported by the Swiss National Science Foundation and by the European Research Council advanced grant MATRICs (ERC grant agreement no. 226172) under the European Community's Seventh Framework Programme. P. O. H. is supported by a NERC UK grant NE/I010912/1 and previously through NERC UK/INSU France QUEST-DESIRE project. E. L. H. was supported by ETH Competence Center Environment and Sustainability's grant MAIOLICA. H. T. and G. C. wish to thank Xiaofeng Xu for assistance with formatting inputs and setting up earlier DLEM model simulations. We thank two anonymous referees for their comments that improved this manuscript.

Edited by: A. Arneth 


\section{References}

Avis, C., Weaver, A. J., and Meissner, K. J.: Reduction in areal extent of high-latitude wetlands in response to permafrost thaw, Nat. Geosci., 4, 444-448, doi:10.1038/ngeo1160, 2011.

Bartlett, K. and Harriss, R.:Review and assessment of methane emissions from wetlands, Chemosphere, 26, 261-320, doi:10.1016/0045-6535(93)90427-7, 1993.

Bartlett, K. Bartlett, D., Harriss, R., and Sebacher, D.:Methane emissions along a salt marsh salinity gradient, Biogeochemistry, 3,183-202, doi:10.1007/BF02187365, 1987.

Beck, V., Chen, H., Gerbig, C., Bergamaschi, P., Bruhwiler, L., Houweling, S., Röckmann, T., Kolle, O., Steinbach, J., Koch, T., Sapart, C. J., van der Veen, C., Frankenberg, C., Andreae, M. O., Artaxo, P., Longo, K., M., and Wofsy, S. C.:Methane airborne measurements and comparison to global models during BARCA, J. Geophys. Res., 171, D15310, doi:10.1029/2011JD017345, 2012.

Beerling, D. J., Fox, A., Stevenson, D. S., and Valdes, P. J.: Enhanced chemistry-climate feedbacks in past greenhouse worlds, Proc. Natl. Acad. Sci., 108, 9770-9775, doi:10.1073/pnas.1102409108, 2011.

Bellisario, L. M., Bubier, J. L., Moore, T., and Chanton, J. P.: Controls on $\mathrm{CH}_{4}$ emissions from a northern peatland, Global Biogeochem. Cy., 13, 81-91, 1999.

Bergamaschi, P., Frankenberg, C., Meirink, J. F., Krol, M., Dentener, F. J., Wagner, T., Platt, U., Kaplan, J. O., Körner, S., Heimann, M., Dlugokencky, E. J., and Goede, A.: Satellite chartography of atmospheric methane from SCIAMACHY on board ENVISAT: 2. Evaluation based on inverse model simulations, J. Geophys. Res., 112, 1-26, doi:10.1029/2006JD007268, 2007.

Beven, K. J. and Kirkby, M. J.: A physically based, variable contributing area model of basin hydrology / Un modèle à base physique de zone d'appel variable de l'hydrologie du bassin versant, Hydrol. Sci. Bull., 24, 43-69, 1979.

Bloom, A., Palmer, P., Fraser, A., and Reay, D.: Largescale controls of methanogenesis inferred from methane and gravity spaceborne data, Science, 327, 322-325, doi:10.1126/science.1175176, 2010.

Boardman, C. P., Gauci, V., Watson, J. S., Blake, S., and Beerling, D. J.: Contrasting wetland $\mathrm{CH}_{4}$ emission responses to simulated glacial atmospheric $\mathrm{CO}_{2}$ in temperate bogs and fens., New Phytol., 192, 1-14, doi:10.1111/j.1469-8137.2011.03849.x, 2011.

Bohn, T. J. and Lettenmaier, D. P.: Systematic biases in large-scale estimates of wetland methane emissions arising from water table formulations, Geophys. Res. Lett., 37, 1-6, doi:10.1029/2010GL045450, 2010.

Bohn, T. J., Lettenmaier, D. P., Sathulur, K., Bowling, L. C., Podest, E., McDonald, K. C., and Friborg, T.: Methane emissions from Western Siberian wetlands: heterogeneity and sensitivity to climate change, Environ. Res. Lett., 2, 045015, doi:10.1088/1748-9326/2/4/045015, 2007.

Bonan, G. B., Oleson, K. W., Fisher, R. A., Lasslop, G., and Reichstein, M.: Reconciling leaf physiological traits and canopy flux data: use of the TRY and FLUXNET databases in the community land model version 4, J. Geophys. Res., 117, 1-19, doi:10.1029/2011JG001913, 2012.

Bousquet, P., Ciais, P., Miller, J. B., Dlugokencky, E. J., Hauglustaine, D. A., Prigent, C., van der Werf, G. R., Peylin, P.,
Brunke, E.-G. G., Carouge, C., Langenfelds, R. L., Lathière, J., Papa, F., Ramonet, M., Schmidt, M., Steele, L. P., Tyler, S. C., White, J. W. C., Werf, G. R. V. D., and Lathiere, J.: Contribution of anthropogenic and natural sources to atmospheric methane variability, Nature, 443, 439-443, doi:10.1038/nature05132, 2006.

Bousquet, P., Ringeval, B., Pison, I., Dlugokencky, E. J., Brunke, E.G., Carouge, C., Chevallier, F., Fortems-Cheiney, A., Frankenberg, C., Hauglustaine, D. A., Krummel, P. B., Langenfelds, R. L., Ramonet, M., Schmidt, M., Steele, L. P., Szopa, S., Yver, C., Viovy, N., and Ciais, P.: Source attribution of the changes in atmospheric methane for 2006-2008, Atmos. Chem. Phys., 11, 3689-3700, doi:10.5194/acp-11-3689-2011, 2011.

Brook, E. J., Harder, S., Severinghaus, J. P., Steig, E. J., and Sucher, C. M.: On the origin and timing of rapid changes in atmospheric methane during the last glacial period, Global Biogeochem. Cy., 14, 559-572, 2000.

Bullock, A. and Acreman, M.: The role of wetlands in the hydrological cycle, Hydrol. Earth Syst. Sci., 7, 358-389, doi:10.5194/hess-7-358-2003, 2003.

Cao, M., Marshall, S., and Gregson, K.: Global carbon exchange and methane emissions from natural wetlands: application of a process-based model, J. Geophys. Res., 101, 14399-14414, 1996.

CCSP, Clark, P. U., Weaver, A. J., Brook, E., Cook, E. R., Delworth, T. L., and Steffen, K.: Abrupt Climate Change, a report by the US Climate Change Science Program and the Subcommittee on Global Change Research, Tech. rep., US Geological Survey, Reston, VA, 2008.

Chanton, J. P., Bauer, L. J. E., Glaser, I. P. A., Siegel, D. I., Kelley, C. A., Tyler, S. C., Romanowicz, E. H., Lazrus, A., Bauer, J. E., and Glaser, P. A.: Radiocarbon evidence for the substrates supporting methane formation within Northern Minnesota peatlands, Geochim. Cosmochim. Acta, 59, 3663-3668, doi:10.1016/0016-7037(95)00240-Z, 1995.

Chappellaz, J., Blunier, T., Kints, S., Dällenbach, A., Barnola, J.M. J., Schwander, J., Raynaud, D., and Stauffer, B.: Changes in the atmospheric $\mathrm{CH}_{4}$ gradient between Greenland and Antarctica during the Holocene, J. Geophys. Res., 102, 15987-15997, 1997.

Chasar, L. S., Chanton, J. P., Glaser, P. H., and Siegel, D. I.: Methane concentration and stable isotope distribution as evidence of rhizospheric processes: comparison of a fen and bog in the glacial Lake Agassiz peatland complex, Ann. Bot., 86, 655663, doi:10.1006/anbo.2000.1172, 2000.

Chen, Y.-H. and Prinn, R. G.: Estimation of atmospheric methane emissions between 1996 and 2001 using a three-dimensional global chemical transport model, J. Geophys. Res., 111, 1-38, doi:10.1029/2005JD006058, 2006.

Christensen, T. R. and Cox. P.:Response of methane emission from arctic tundra to climatic change: results from a model simulation, Tellus B, 47, 301-309, 1995.

Christensen. T. R. Prentice, I. C., Kaplan, J. O., Haxeltine, A., and Sitch, S.: Methane flux from northern wetlands and tundra - An ecosystem source modelling approach, Tellus B, 48, 652-661, 1996.

Cogley, J.: GGHYDRO: global hydrographic data, Peterborough, Ontario, Canada, 1994.

Denman, K. L., Brasseur, G., Chidthaisong, A., Ciais, P., Cox, P. M., Dickinson, R. E., Hauglustaine, D. A., Heinze, C., Holland, E., 
Jacob, D., Lohmann, U., Ramachandran, S., da Silva Dias, P., Wofsy, S., and Zhang, X.: Couplings between changes in the climate system and biogeochemistry, in: Climate Change 2007: The Physical Science Basis, Contribution of Working Group I to the Fourth Assessment Report of the Intergovernmental Panel on Climate Change, edited by: Solomon, S., Qin, D., Manning, M. R., Chen, Z., Marquis, M., Averyt, K., Tignor, M., and Miller, H. L., Cambridge University Press, Cambridge UK and New York, NY, USA, chap. 7, 1-90, 2007.

Dlugokencky, E. J., Walter, B. P., Masarie, K., Lang, P., and Kasischke, E. S.: Measurements of an anomalous global methane increase during 1998, Geophys. Res. Lett., 28, 499-502, 2001.

Dugan, P.: Wetlands in Danger: A World Conservation Atlas, Oxford University Press, New York, NY, 1993.

Eliseev, A. V., Mokhov, I. I., Arzhanov, M. M., Demchenko, P. F., and Denisov, S. N.: Interaction of the methane cycle and processes in wetland ecosystems in a climate model of intermediate complexity, Izvestiya, Atmos. Ocean. Phys., 44, 139-152, doi:10.1134/S0001433808020011, 2008.

Ferretti, D. F., Miller, J. B., White, J. W. C., Lassey, K. R., Lowe, D. C., and Etheridge, D. M.: Stable isotopes provide revised global limits of aerobic methane emissions from plants, Atmos. Chem. Phys., 7, 237-241, doi:10.5194/acp-7-237-2007, 2007.

Finlayson, C., Davidson, N. C., Spiers, A., and Stevenson, N.: Global wetland inventory - current status and future priorities, Mar. Freshwater Res., 50, 717-727, 1999.

Frankenberg, C., Bergamaschi, P., Butz, A., Houweling, S., Meirink, J. F., Notholt, J., Petersen, A. K., Schrijver, H., Warneke, T., and Aben, I.: Tropical methane emissions: a revised view from SCIAMACHY onboard ENVISAT, Geophys. Res. Lett., 35, 1-5, L15811, doi:10.1029/2008GL034300, 2008.

Frey, K. E. and Smith, L. C.: How well do we know northern land cover? Comparison of four global vegetation and wetland products with a new ground-truth database for West Siberia, Global Biogeochem. Cy., 21, 1-15, GB1016, doi:10.1029/2006GB002706, 2007.

Friedlingstein, P., Cox, P. M., Betts, R., Bopp, L., von Bloh, W., Brovkin, V., Cadule, P., Doney, S., Eby, M., Fung, I., Bala, G., John, J., Jones, C., Joos, F., Kato, T., Kawamiya, M., Knorr, W., Lindsay, K., Matthews, H. D., Raddatz, T., Rayner, P. J., Reick, C. H., Roeckner, E., Schnitzler, K.-G., Schnur, R., Strassman, K., Weaver, A. J., Yoshikawa, C., and Zeng, N.: Climatecarbon cycle feedback analysis: results from the C4MIP model intercomparison, J. Climate, 19, 3337-3354, 2006.

Fung, I. Y., Prather, M., Fraser, P. J., John, J., Lerner, J., Matthews, E., and Steele, L. P.: Three-dimensional model synthesis of the global methane cycle, J. Geophys. Res., 96, 1303313065, 1991.

Gedney, N., Cox, P. M., and Huntingford, C.: Climate feedback from wetland methane emissions, Geophys. Res. Lett., 31, 1-4, doi:10.1029/2004GL020919, 2004.

Glagolev, M., Kleptsova, I., Filippov, I., Maksyutov, S., and Machida, T.: Regional methane emission from West Siberia mire landscapes, Environ. Res. Lett., 6, 1-7, 045214, doi:10.1088/1748-9326/6/4/045214, 2011.

Goll, D. S., Brovkin, V., Parida, B. R., Reick, C. H., Kattge, J., Reich, P. B., van Bodegom, P. M., and Niinemets, Ü.: Nutrient limitation reduces land carbon uptake in simulations with a model of combined carbon, nitrogen and phosphorus cycling, Biogeo- sciences, 9, 3547-3569, doi:10.5194/bg-9-3547-2012, 2012.

Gorham, E.: Northern peatlands: role in the carbon cycle and probable responses to climatic warming, Ecol. Appl., 1, 182-195, 1991.

Guerrero, O. J., Jiménez, R., Lin, J. C., Diskin, G. S., Sachse, G. W., Kort, E. A., and Kaplan, J. O.: Assessing methane fluxes in Colombia from Lagrangian simulation analysis of aircraft-borne measurements during TC4, in: NASA Goddard Space Flight Center Seminar, vol. 108, 1 pp., Greenbelt, MD, 2011.

Hansen, J., Ruedy, R., Sato, M., and Lo, K.: Global surface temperature change, Rev. Geophys., 48, 1-29, RG4004, doi:10.1029/2010RG000345, 2010.

Harriss, R., Wofsy, S., Hoell, J. M. J., Bendura, R., Drewry, J., McNeal, R. J., Pierce, D., Rabine, V., and Snell, R. L.: The Arctic Boundary Layer Expedition (ABLE-3B): July-August 1990, J. Geophys. Res., 99, 1635-1643, 1994.

Hein, R., Crutzen, P. J., and Heimann, M.: An inverse modeling approach to investigate the global atmospheric methane cycle, Global Biogeochem. Cy., 11, 43-76, 1997.

Hickler, T., Smith, B., Prentice, C. I., Mjöfors, K., Miller, P., Arneth, A., and Sykes, M. T.: $\mathrm{CO}_{2}$ fertilization in temperate FACE experiments not representative of boreal and tropical forests, Glob. Change Biol., 14, 1531-1542, doi:10.1111/j.13652486.2008.01598.x, 2008.

Hodson, E. L., Poulter, B., Zimmermann, N. E., Prigent, C., and Kaplan, J. O.: The El Niño-Southern Oscillation and wetland methane interannual variability, Geophys. Res. Lett., 38, 1-4, doi:10.1029/2011GL046861, 2011.

Hopcroft, P. O., Valdes, P. J., and Beerling, D. J.: Simulating idealized Dansgaard-Oeschger events and their potential impacts on the global methane cycle, Quat. Sci. Rev., 30, 3258-3268, doi:10.1016/j.quascirev.2011.08.012, 2011.

Houweling, S., Dentener, F., and Lelieveld, J.: Simulation of preindustrial atmospheric methane to constrain the global source strength of natural wetlands, J. Geophys. Res., 105, 1724317255, 2000.

Houweling, S., Röckmann, T., Aben, I., Keppler, F., Krol, M., Meirink, J. F., and Dlugokencky, E. J.: Atmospheric constraints on global emissions of methane from plants, Geophys. Res. Lett., 33, 1-5, doi:10.1029/2006GL026162, 2006.

Huber, C., Leuenberger, M., Spahni, R., Flückiger, J., Schwander, J., Stocker, T. F., Johnsen, S., Landais, A., and Jouzel, J.: Isotope calibrated Greenland temperature record over Marine Isotope Stage 3 and its relation to $\mathrm{CH}_{4}$, Earth Planet. Sc. Lett., 243, 504-519, doi:10.1016/j.epsl.2006.01.002, 2006.

Hungate, B. A., Dukes, J. S., Shaw, M. R., Luo, Y., and Field, C. B.: Nitrogen and climate change, Science, 302, 15121513, doi:10.1126/science.1091390, 2003.

Hurtt, G. C., Frolking, S., Fearon, M. G., Moore, B., Shevliakova, E., Malyshev, S., Pacala, S. W., and Houghton, R. A.: The underpinnings of land-use history: three centuries of global gridded land-use transitions, wood-harvest activity, and resulting secondary lands, Glob. Change Biol., 12, 1208-1229, doi:10.1111/j.1365-2486.2006.01150.x, 2006.

Hutchin, P. R., Press, M. C., Lee, J. A., and Ashenden, T. W.: Elevated concentrations of $\mathrm{CO}_{2}$ may double methane emissions from mires, Glob. Change Biol., 1, 125-128, 1995.

IPCC: Emissions Scenarios, Special Report of the Intergovernmental Panel on Climate Change, Cambridge University Press, Cam- 
bridge UK, 2000.

Kang, H., Freeman, C., and Ashendon, T. W.: Effects of elevated $\mathrm{CO}_{2}$ on fen peat biogeochemistry, Sci. Total Environ., 279, 45$50,2001$.

Kaplan, J. O.: Wetlands at the Last Glacial Maximum: distribution and methane emissions, Geophys. Res. Lett., 29, 3-6, doi:10.1029/2001GL013366, 2002.

Kaplan, J. O., Folberth, G., and Hauglustaine, D. A.: Role of methane and biogenic volatile organic compound sources in late glacial and Holocene fluctuations of atmospheric methane concentrations, Global Biogeochem. Cy., 20, 1-16, doi:10.1029/2005GB002590, 2006.

Kirschbaum, M. U., Bruhn, D., Etheridge, D. M., Evans, J. R., Farquhar, G. D., Gifford, R. M., Paul, K. I., and Winters, A. J.: A comment on the quantitative significance of aerobic methane release by plants, Funct. Plant Biol., 33, 521-530, doi:10.1071/FP06051, 2006.

Koven, C. D., Ringeval, B., Friedlingstein, P., Ciais, P., Cadule, P., Khvorostyanov, D., Krinner, G., and Tarnocai, C.: Permafrost carbon-climate feedbacks accelerate global warming., Proc. Natl. Acad. Sci., 108, 14769-14774, doi:10.1073/pnas.1103910108, 2011.

Leff, B., Ramankutty, N., and Foley, J. A.: Geographic distribution of major crops across the world, Global Biogeochem. Cy., 18, 27, GB1009, doi:10.1029/2003GB002108, 2004.

Lehner, B. and Döll, P.: Development and validation of a global database of lakes, reservoirs and wetlands, J. Hydrol., 296, 1-22, doi:10.1016/j.jhydrol.2004.03.028, 2004.

Loulergue, L., Schilt, A., Spahni, R., Masson-Delmotte, V., Blunier, T., Lemieux, B., Barnola, J.-M., Raynaud, D., Stocker, T. F., and Chappellaz, J.: Orbital and millennial-scale features of atmospheric $\mathrm{CH}_{4}$ over the past 800,000 years, Nature, $453,383-386$, doi:10.1038/nature06950, 2008.

Loveland, T., Reed, B., and Brown, J.: Development of a global land cover characteristics database and IGBP DISCover from $1 \mathrm{~km}$ AVHRR data, Int. J. Remote Sens., 21, 1303-1330, 2000.

Matthews, E. and Fung, I. Y.: Methane emission from natural wetlands: global distribution, area, and environmental characteristics, Global Biogeochem. Cy., 1, 61-86, 1987.

Meehl, G. A., Stocker, T. F., Collins, W. D., Friedlingstein, P., Gaye, A. T., Gregory, J. M., Kitoh, A., Knutti, R., Murphy, J. M., Noda, A., Raper, S. C. B., Watterson, I. G., Weaver, A. J., and Zhao, Z.-C.: Global climate projections, in: Climate Change 2007: The Physical Science Basis, Contribution of Working Group I to the Fourth Assessment Report of the Intergovernmental Panel on Climate Change, edited by: Solomon, S., Qin, D., Manning, M., Chen, Z., Marquis, M., Averyt, K., Tignor, M., and Miller, H., Cambridge University Press, Cambridge, UK and New York, NY, US A., chap. 10, pp. 748-844, 2007.

Megonigal, J. P. and Schlesinger, W.: Enhanced $\mathrm{CH}_{4}$ emissions from a wetland soil exposed to elevated $\mathrm{CO}_{2}$, Biogeochemistry, 37, 77-88, 1997.

Melack, J. M., Hess, L. L., Gastil, M., Forsberg, B. R., Hamilton, S. K., Lima, I. B. T., Novo, E. M. E., Barbara, S., Corners, H., and Espaciais, D. P.: Regionalization of methane emissions in the Amazon Basin with microwave remote sensing, Glob. Change Biol., 10, 530-544, doi:10.1111/j.15298817.2003.00763.x, 2004.
Mikaloff Fletcher, S. E., Tans, P. P., Bruhwiler, L. M., Miller, J. B., and Heimann, M.: $\mathrm{CH}_{4}$ sources estimated from atmospheric observations of $\mathrm{CH}_{4}$ and its ${ }^{13} \mathrm{C} /{ }^{12} \mathrm{C}$ isotopic ratios: 1. Inverse modeling of source processes, Global Biogeochem. Cy., 18, 117, doi:10.1029/2004GB002223, 2004.

Miller, J. B., Gatti, L. V., D’Amelio, M. T. S., Crotwell, A. M., Dlugokencky, E. J., Bakwin, P., Artaxo, P., and Tans, P. P.: Airborne measurements indicate large methane emissions from the Eastern Amazon basin, Geophys. Res. Lett., 34, 1-5, doi:10.1029/2006GL029213, 2007.

Mitsch, W. and Gosselink, J. G.: Wetlands, John Wiley \& Sons, New York, 3rd edn., 2000.

Mokhov, I. I., Eliseev, A. V., and Denisov, S. N.: Model diagnostics of variations in methane emissions by wetlands in the second half of the 20th century based on reanalysis data, Doklady Earth Sci., 417, 1293-1297, doi:10.1134/S1028334X07080375, 2007.

Moore, T. and Roulet, N.: Spatial and temporal variations of methane flux from subarctic/northern boreal fens, Global Biogeochem. Cy., 4, 29-46, 1990.

National Wetlands Working Group: Wetlands of Canada, Sustainable Development Branch, Environment Canada, Ottawa, Ontario, and Polyscience Publications Inc., Montreal, Quebec, 1988.

NOAA National Climatic Data Center: State of the Climate: Global Analysis for Annual 2003, available at: http://www.ncdc.noaa. gov/sotc/global/2003/13, 2003.

OECD: Guidelines for aid agencies for improved conservation and sustainable use of tropical and sub-tropical wetlands, Tech. rep., Organization for Economic Co-operation and Development, Paris, France, 1996.

ORNL DAAC: MODIS subsetted land products, available at: http: //daac.ornl.gov/MODIS/modis.html, 2000.

Page, S. E., Rieley, J. O., and Banks, C. J.: Global and regional importance of the tropical peatland carbon pool, Glob. Change Biol., 17, 798-818, doi:10.1111/j.1365-2486.2010.02279.x, 2011.

Pancotto, V., Bodegom, P. V., Hal, J. V., van Logtestijn, R., Blokker, P., Toet, S., and Aerts, R.: $\mathrm{N}$ deposition and elevated $\mathrm{CO}_{2}$ on methane emissions: differential responses of indirect effects compared to direct effects through litter chemistry feedbacks, J. Geophys. Res., 115, G02001, doi:10.1029/2009JG001099, 2010.

Papa, F., Prigent, C., Aires, F., Jimenez, C., Rossow, W. B., and Matthews, E.: Interannual variability of surface water extent at the global scale, 1993-2004, J. Geophys. Res., 115, 1-17, doi:10.1029/2009JD012674, 2010.

Peregon, A., Maksyutov, S., Kosykh, N. P., and MironychevaTokareva, N. P.: Map-based inventory of wetland biomass and net primary production in Western Siberia, J. Geophys. Res., 113, 1-12, doi:10.1029/2007JG000441, 2008.

Petrescu, A. M. R., van Huissteden, J., Jackowicz-Korczynski, M., Yurova, A., Christensen, T. R., Crill, P. M., Bäckstrand, K., Maximov, T. C.: Modelling $\mathrm{CH}_{4}$ emissions from arctic wetlands: effects of hydrological parameterization, Biogeosciences, 5, 111121, doi:10.5194/bg-5-111-2008, 2008.

Pickett-Heaps, C. A., Jacob, D. J., Wecht, K. J., Kort, E. A., Wofsy, S. C., Diskin, G. S., Worthy, D. E. J., Kaplan, J. O., Bey, I., and Drevet, J.: Magnitude and seasonality of wetland methane emissions from the Hudson Bay Lowlands (Canada), 
Atmos. Chem. Phys., 11, 3773-3779, doi:10.5194/acp-11-37732011, 2011.

Potter, C.: An ecosystem simulation model for methane production and emission from wetlands, Global Biogeochem. Cy., 11, 495506, 1997.

Poulter, B., Aragão, L., Heyder, U., Gumpenberger, M., Heinke, J., Langerwisch, F., Rammig, A., Thonicke, K., and Cramer, W.: Net biome production of the Amazon Basin in the 21st century, Glob. Change Biol., 16, 2062-2075, doi:10.1111/j.13652486.2009.02064.x, 2010.

Prentice, I., Farquhar, G., Fasham, M., Goulden, M., Heimann, M., Jaramillo, V., Kheshgi, H., Quéré, C. L., Scholes, R., and Wallace, D.: The carbon cycle and atmospheric carbon dioxide, in: IPCC Third Assessment Report: Climate Change 2001 (TAR), edited by: Pitelka, L. and Ramirez Rojas, A., Cambridge University Press, Cambridge UK, chap. 3, 1-56, 2001.

Prigent, C., Papa, F., Aires, F., Rossow, W. B., and Matthews, E.: Global inundation dynamics inferred from multiple satellite observations, 1993-2000, J. Geophys. Res., 112, 1-13, doi:10.1029/2006JD007847, 2007.

Riley, W. J., Subin, Z. M., Lawrence, D. M., Swenson, S. C., Torn, M. S., Meng, L., Mahowald, N. M., and Hess, P.: Barriers to predicting changes in global terrestrial methane fluxes: analyses using CLM4Me, a methane biogeochemistry model integrated in CESM, Biogeosciences, 8, 1925-1953, doi:10.5194/bg-8-19252011, 2011.

Ringeval, B.: Interactions entre climat et émissions de méthane par les zones humides à l'échelle globale, $\mathrm{PhD}$ thesis, Universite Pierre \& Marie Curie, Paris, France, 2011.

Ringeval, B., de Noblet-Ducoudré, N., Ciais, P., Bousquet, P., Prigent, C., Papa, F., and Rossow, W. B.: An attempt to quantify the impact of changes in wetland extent on methane emissions on the seasonal and interannual time scales, Global Biogeochem. Cy., 24, 1-12, doi:10.1029/2008GB003354, 2010.

Ringeval, B., Friedlingstein, P., Koven, C., Ciais, P., de NobletDucoudra, N., Decharme, B., and Cadule, P.: Climate- $\mathrm{CH}_{4}$ feedback from wetlands and its interaction with the climate$\mathrm{CO}_{2}$ feedback, Biogeosciences, 8, 2137-2157, doi:10.5194/bg8-2137-2011, 2011.

Ringeval, B., Decharme, B., Piao, S. L., Ciais, P., Papa, F., de Noblet-Ducoudré, N., Prigent, C., Friedlingstein, P., Gouttevin, I., Koven, C. D., and Ducharne, A.: Modelling subgrid wetland in the ORCHIDEE global land surface model: evaluation against river discharges and remotely sensed data, Geosci. Model Dev., 5, 683-735, doi:http://dx.doi.org/10.5194/ gmdd-5-683-201210.5194/gmdd-5-683-2012, 2012.

Roulet, N., Jano, A., Kelly, C., and Klinger, L.: Role of the Hudson Bay Lowland as a source of atmospheric methane, J. Geophys. Res., 99, 1439-1454, 1994.

Saarnio, S. and Silvola, J.: Effects of increased $\mathrm{CO}_{2}$ and $\mathrm{N}$ on $\mathrm{CH}_{4}$ efflux from a boreal mire: a growth chamber experiment, Oecologia, 119, 349-356, 1999.

Saarnio, S., Järvio:, S., Saarinen, T., Vasander, H., and Silvola, J.: Minor changes in vegetation and carbon gas balance in a boreal mire under a raised $\mathrm{CO}_{2}$ or $\mathrm{NH}_{4} \mathrm{NO}_{3}$ supply, Ecosystems, 6, 4660, doi:10.1007/s10021-002-0208-3, 2003.

Sanderson, M. G.: Hadley Centre Technical Note 32: Global Distribution of Freshwater Wetlands for use in STOCHEM, UK Met Office, London, UK, 1-10, 2001.
Schroeder, R., Rawlins, M. A., McDonald, K. C., Podest, E., Zimmermann, R., and Kueppers, M.: Satellite microwave remote sensing of North Eurasian inundation dynamics: development of coarse-resolution products and comparison with high-resolution synthetic aperture radar data, Environ. Res. Lett., 5, 015003, doi:10.1088/1748-9326/5/1/015003, 2010.

Segers, R. and Leffelaar, P. A.: Modeling methane fluxes in wetlands with gas-transporting plants, 3. Plot scale, J. Geophys. Res., 106, 3541-3558, doi:10.1029/2000JD900482, 2001.

Shindell, D. T., Walter, B. P., and Faluvegi, G.: Impacts of climate change on methane emissions from wetlands, Geophys. Res. Lett., 31, L21202, doi:10.1029/2004GL021009, 2004.

Silvola, J., Saarnio, S., Foot, J., Sundh, I., Greenup, A., Heijmans, M., Ekberg, A., Mitchell, E., and van Breemen, N.: Effects of elevated $\mathrm{CO}_{2}$ and $\mathrm{N}$ deposition on $\mathrm{CH}_{4}$ emissions from European mires, Global Biogeochem. Cy., 17, 1068-1080, doi:10.1029/2002GB001886, 2003.

Singarayer, J. S., Valdes, P. J., Friedlingstein, P., Nelson, S., and Beerling, D. J.: Late Holocene methane rise caused by orbitally controlled increase in tropical sources., Nature, 470, 82-85, doi:10.1038/nature09739, 2011.

Smith, L. K., Lewis, W. M., Chanton, J. P., Cronin, G., and Hamilton, S. K.: Methane emissions from the Orinoco River floodplain, Venezuela, Biogeochemistry, 51, 113-140, 2000.

Spahni, R., Wania, R., Neef, L., van Weele, M., Pison, I., Bousquet, P., Frankenberg, C., Foster, P. N., Joos, F., Prentice, I. C., and van Velthoven, P.: Constraining global methane emissions and uptake by ecosystems, Biogeosciences, 8, 1643-1665, doi:10.5194/bg-8-1643-2011, 2011.

Stillwell-Soller, L., Klinger, L., Pollard, D., and Thompson, S. L.: The global distribution of freshwater wetlands, Tech. Rep., September, National Center for Atmospheric Research, Boulder, Colorado, USA, 1995.

Sulman, B. N., Desai, A. R., Schroeder, N. M., Ricciuto, D., Barr, A., Richardson, A. D., Flanagan, L. B., Lafleur, P. M., Tian, H., Chen, G., Grant, R. F., Poulter, B., Verbeeck, H., Ciais, P., Ringeval, B., Baker, I. T., Schaefer, K., Luo, Y., and Weng, E.: Impact of hydrological variations on modeling of peatland $\mathrm{CO}_{2}$ fluxes: results from the North American carbon program site synthesis, J. Geophys. Res., 117, 1-21, doi:10.1029/2011JG001862, 2012.

Subin, Z. M., Koven, C. D., Riley, W. J., Torn, M. S., Lawrence, D. M., and Swenson, S. C.:Effects of soil moisture on the responses of soil temperatures to climate change in cold regions, Journal of Climate, in press, 2012.

Tang, J. and Zhuang, Q.: Equifinality in parameterization of process-based biogeochemistry models: a significant uncertainty source to the estimation of regional carbon dynamics, J. Geophys. Res., 113, 1-13, doi:10.1029/2008JG000757, 2008.

Tarnocai, C., Canadell, J. G., Schuur, E. A. G., Kuhry, P., Mazhitova, G., and Zimov, S. A.: Soil organic carbon pools in the northern circumpolar permafrost region, Global Biogeochem. Cy., 23, 1-11, doi:10.1029/2008GB003327, 2009.

Tian, H., Xu, X., Liu, M., Ren, W., Zhang, C., Chen, G., and Lu, C.: Spatial and temporal patterns of $\mathrm{CH}_{4}$ and $\mathrm{N}_{2} \mathrm{O}$ fluxes in terrestrial ecosystems of North America during 1979-2008: application of a global biogeochemistry model, Biogeosciences, 7, 2673-2694, doi:10.5194/bg-7-2673-2010, 2010. 
Tian, H., Xu, X., Lu, C., Liu, M., Ren, W., Chen, G., Melillo, J. M., and Liu, J.: Net exchanges of $\mathrm{CO}_{2}, \mathrm{CH}_{4}$, and $\mathrm{N}_{2} \mathrm{O}$ between China's terrestrial ecosystems and the atmosphere and their contributions to global climate warming, J. Geophys. Res., 116, 113, doi:10.1029/2010JG001393, 2011.

Turunen, J., Tomppo, E., Tolonen, K., and Reinikainen, A.: Estimating carbon accumulation rates of undrained mires in Finland - application to boreal and subarctic regions, The Holocene, 12, 69-80, doi:10.1191/0959683602hl522rp, 2002.

Valdes, P. J., Beerling, D. J., and Johnson, C. E.: The ice age methane budget, Geophys. Res. Lett., 32, 1-4, doi:10.1029/2004GL021004, 2005.

van Bodegom, P. and Goudriaan, J.: A mechanistic model on methane oxidation in a rice rhizosphere, Biogeochemistry, 55, 145-177, 2001.

van Bodegom, P., Wassmann, R., and Metra-Corton, T.: A processbased model for methane emission predictions from flooded rice paddies, Global Biogeochem. Cy., 15, 247-263, 2001.

van Bodegom, P., Verburg, P. H., and Denier van der Gon, H. A. C.: Upscaling methane emissions from rice paddies: problems and possibilities, Global Biogeochem. Cy., 16, 1014, doi:10.1029/2000GB001381, 2002.

van Groenigen, K. J., Osenberg, C. W., and Hungate, B. A.: Increased soil emissions of potent greenhouse gases under increased atmospheric $\mathrm{CO}_{2}$, Nature, 475, 214-216, doi:10.1038/nature10176, 2011.

van Huissteden, J.: Methane emission from northern wetlands in Europe during Oxygen Isotope Stage 3, Quat. Sci. Rev., 23, 1989-2005, doi:10.1016/j.quascirev.2004.02.015, 2004.

van Huissteden, J., Berrittella, C., Parmentier, F. J. W., Mi, Y., Maximov, T. C., and Dolman, A. J.: Methane emissions from permafrost thaw lakes limited by lake drainage, Nat. Clim. Change, 1, 119-123, doi:10.1038/nclimate1101, 2011.

van Huissteden, J., Berrittella, C.,Parmentier, F. J. W., Mi, Y., Maximov, T. C., and Dolman, A. J.:Methane emissions from permafrost thaw lakes limited by lake drainage, Nature Climate Change, 1, 119-123, doi:10.1038/nclimate1101, 2011.

Vann, C. D. and Megonigal, J. P.: Elevated $\mathrm{CO}_{2}$ and water depth regulation of methane emissions: comparison of woody and nonwoody wetland plant species, Global Biogeochem. Cy., 63, 117134, 2003.

Walker, D. A., Raynolds, M. K., Daniëls, F. J., Einarsson, E., Elvebakk, A., Gould, W. A., Katenin, A. E., Kholod, S. S., Markon, C. J., Melnikov, E. S., Moskalenko, N. G., Talbot, S. S., Yurtsev, B. A., and CAVM: The circumpolar arctic vegetation map, J. Veg. Sci., 16, 267-282, doi:10.1111/j.16541103.2005.tb02365.x, 2005.

Walter, B. P.: Development of a process-based model to derive methane emissions from natural wetlands for climate studies, Ph.D. thesis, Max-Planck-Institut Für Meteorologie, Hamburg, Germany, 1998.

Walter, B. P. and Heimann, M.: A process-based, climate-sensitive model to derive methane emissions from natural wetlands: application to five wetland sites, sensitivity to model parameters, and climate, Global Biogeochem. Cy., 14, 745-765, 2000.

Walter, B. P., Heimann, M., Shannon, R. D., and White, J.: A process-based model to derive methane emissions from natural wetlands, Geophys. Res. Lett., 23, 3731-3734, 1996.
Walter, B. P., Heimann, M., and Matthews, E.: Modeling modern methane emissions from natural wetlands, 1: Model description and results, J. Geophys. Res., 106, 34189-34206, 2001.

Walter Anthony, K. M., Chanton, J. P., Chapin, S. F. I., Schuur, E. I. G., Zimov, S. A., and Iii, F. S. C.: Methane production and bubble emissions from arctic lakes: isotopic implications for source pathways and ages, J. Geophys. Res., 113, G00A08, doi:10.1029/2007JG000569, 2008.

Wang, J. S., Logan, J. A., McElroy, M. B., Duncan, B. N., Megretskaia, I. A., and Yantosca, R. M.: A 3-D model analysis of the slowdown and interannual variability in the methane growth rate from 1988 to 1997, Global Biogeochem. Cy., 18, 1-31, doi:10.1029/2003GB002180, 2004

Wania, R., Ross, I., and Prentice, C. I.: Integrating peatlands and permafrost into a dynamic global vegetation model: 1. Evaluation and sensitivity of physical land surface processes, Global Biogeochem. Cy., 23, 1-19, doi:10.1029/2008GB003412, 2009a.

Wania, R., Ross, I., and Prentice, C. I.: Integrating peatlands and permafrost into a dynamic global vegetation model: 2. Evaluation and sensitivity of vegetation and carbon cycle processes, Global Biogeochem. Cy., 23, 1-15, doi:10.1029/2008GB003413, 2009b.

Wania, R., Ross, I., and Prentice, I. C.: Implementation and evaluation of a new methane model within a dynamic global vegetation model: LPJ-WHyMe v1.3.1, Geosci. Model Dev., 3, 565-584, doi:10.5194/gmd-3-565-2010, 2010.

Wania, R., Melton, J. R., Hodson, E. L., Poulter, B., Ringeval, B. Spahni, R., Bohn, T. J., Avis, C. A., Chen, G., Eliseev, A. V., Hopcroft, P. O., Riley, W. J., Subin, Z. M., Tian, H., van Bodegom, P., Kleinen, T., Yu, Z., Singarayer, J. S., Zürcher, S., Lettenmaier, D. P., Beerling, D. J., Denisov, S. N., Prigent, C., Papa, F., and Kaplan, J. O.: Present state of global wetland extent and wetland methane modelling: methodology of a model intercomparison project (WETCHIMP), Geosci. Model Dev. Discuss., 5, 4071-4136, doi:10.5194/gmdd-5-4071-2012, 2012.

Wetlands International: Ramsar Database, Wetlands International, Wageningen, The Netherlands, 2002.

Whiticar, M. J.: Carbon and hydrogen isotope systematics of bacterial formation and oxidation of methane, Chem. Geol., 161, 291314, doi:10.1016/S0009-2541(99)00092-3, 1999.

Whiting, G. J. and Chanton, J. P.: Primary production control of methane emission from wetlands, Nature, 364, 794-795, 1993.

Williams, M.: Wetlands: A Threatened Landscape, Blackwell Publishing Ltd, Cambridge Massachusetts, USA, 1991.

Winderlich, J., Chen, H., Gerbig, C., Seifert, T., Kolle, O., Lavrič, J. V., Kaiser, C., Höfer, A., and Heimann, M.: Continuous low-maintenance $\mathrm{CO}_{2} / \mathrm{CH}_{4} / \mathrm{H}_{2} \mathrm{O}$ measurements at the Zotino Tall Tower Observatory (ZOTTO) in Central Siberia, Atmos. Meas. Tech., 3, 1113-1128, doi:10.5194/amt-3-1113-2010, 2010.

Woo, M.-K. and Winter, T. C.: The role of permafrost and seasonal frost in the hydrology of northern wetlands in North America, J. Hydrol., 141, 5-31, 1993.

Woo, M.-K. and Young, K. L.: High Arctic wetlands: their occurrence, hydrological characteristics and sustainability, J. Hydrol. 320, 432-450, doi:10.1016/j.jhydrol.2005.07.025, 2006.

Worthy, D. E. J., Levin, I., Hopper, F., Ernst, M. K., and Trivett, N. B. A.: Evidence for a link between climate and northern 
wetland methane emissions, J. Geophys. Res., 105, 4031-4038, doi:10.1029/1999JD901100, 2000.

$\mathrm{Xu}, \mathrm{X}$. and Tian, H.: Methane exchange between marshland and the atmosphere over China during 1949-2008, Global Biogeochem. Cy., 26, 1-14, doi:10.1029/2010GB003946, 2012.

$\mathrm{Yu}, \mathrm{Z}$.: Northern peatland carbon stocks and dynamics: a review, Biogeosciences, 9, 4071-4085, doi:10.5194/bg-9-40712012, 2012.

Yu, Z., Loisel, J., Brosseau, D. P., Beilman, D. W., and Hunt, S. J.: Global peatland dynamics since the Last Glacial Maximum, Geophys. Res. Lett., 37, 1-5, doi:10.1029/2010GL043584, 2010.
Zaehle, S., Friedlingstein, P., and Friend, A. D.: Terrestrial nitrogen feedbacks may accelerate future climate change, Geophys. Res. Lett., 37, 1-5, doi:10.1029/2009GL041345, 2010.

Zhuang, Q., Melillo, J. M., Sarofim, M. C., Kicklighter, D. W., McGuire, A. D., Felzer, B. S., Sokolov, A., Prinn, R. G., Steudler, P. A., and $\mathrm{Hu}, \mathrm{S}$.: $\mathrm{CO}_{2}$ and $\mathrm{CH}_{4}$ exchanges between land ecosystems and the atmosphere in northern high latitudes over the 21 st century, Geophys. Res. Lett., 33, 1-5, doi:10.1029/2006GL026972, 2006. 